0

\title{
EFFECT OF IONIZING RADIATION ON
}

\section{A SERIES OF SATURATED POLYESTERS}

\section{D'Alelio, Häberli, and Pezdirtz}

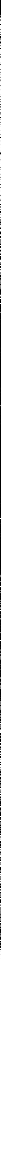




\title{
EFFECT OF IONIZING RADIATION ON
}

\section{A SERIES OF SATURATED POLYESTERS}

\author{
G. F. D'Alelio, Roland Häberli, \\ and George F. Pezdirtz
}

\author{
Accepted by the \\ NASA Research Advisory Committee on Materials \\ from \\ Department of Chemistry, \\ University of Notre Dame
}

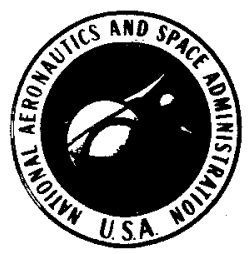


FOREWORD

This report was offered as a member report to the NASA Research Advisory Committee on Materials by Dr. G. F. D'Alelio. It represents material abstracted from the $\mathrm{Ph}$. D. thesis of $\mathrm{Dr}$. George F. Pezdirtz and from postdoctoral work of Dr. Roland Häberli prepared during their courses of study under the direction of Dr. D'Alelio of the Department of Chemistry, University of Notre Dame. The research was supported by fellowships sponsored by William W. Barton. A preliminary version of this report entitled "The Effect of Ionizing Radiation on Saturated Linear Polyesters" was presented by Dr. D'Alelio at the Macromolecular Symposium of the International Union of Pure and Applied Chemistry held in Wiesbaden, Germany, on October 12-16, 1959. Continued interest in the subject is considered to warrant NASA publication in the present form. 
CONTENTS

Page

INTRODUCTION . . . . . . . . . . . . . . . . . . . I

EXPERIMENTAL . . . . . . . . . . . . . . . . . 4

REAGENTS AND POLYESTER SYNTHESES . . . . . . . . . . . . 4

IRRADIATION OF POLYESTERS ....................... 4

INTRINSIC VISCOSITIES ............... 5

CORRELATION OF INIRINSIC VISCOSITY WITH ABSORBED RADIATION DOSE . . . 5

EFFECT OF DOSE RATE AND SOURCE OF IONIZING RADIATION ON INIRINSIC

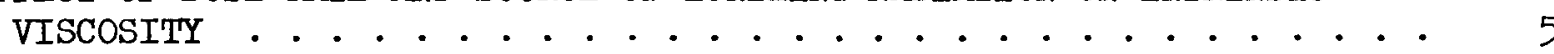

INFLUENCE OF AIR AND FILM THICKNESS ON EFFECTS OF IONIZING

RADIATION ........................ 6

INFLUENCE OF ORIENTATION ON EFFECT OF IONIZING RADIATION . . . . . 6

EFFECT OF POSTHEATING ON IRRADIATED POLYTETRAMETHYLENE SEBACATE . . . 6

CHANGES IN ELEMENTAL COMPOSITIONS OF POLYMER ON IRRADIATION . . . . . 7

Effect of Thickness on Loss of Welght of Irradiated Sample . . . . . 7

Elemental Analysis of Polyesters Before and After Irradiation . . . 7

Analysis of Gases Resulting From Irradiation of Polyesters . . . . . 7

IRRADIATION GRAFTING OF STYRENE AND DIVINIBENZENE TO POLYMERS

AND EFFECTS ON CERTAIN PROPERTIES . . . . . . . . . . . . 8

Effect of Irradiation on Intrinsic Viscosity of Mixtures of
Polyesters and Divinylbenzene . . . . . . . . . . 8

Effect of Irradiation on Solubility of a Mixture of Polyester

and Divinylbenzene or Styrene . . . . . . . . . . . . . 8

Swelling Index of Irradiated Polymers . . . . . . . . . 8

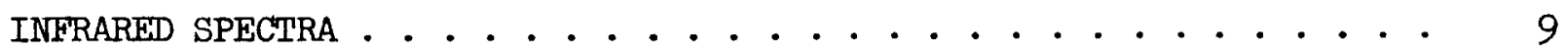

DIAGNOSTIC SAPONIFICATION OF IRRADIATED POLYTETRAMETHYLENE

SEBACATE . . . . . . . . . . . . . . . . .

\section{DISCUSSION}

EFFECT OF IRRADIATION ON INTRINSIC VISCOSITY OF SATURATED LINEAR

POLYESTERS . . . . . . . . . . . . . . . . . . . . 11

Straight-Chain Polyesters ............... 11

Branched Diol Polyesters.................. 14

Polyesters of Branched Dicarboxylic Acids . . . . . . . . . 16

Polyesters of Branched Diols and Branched Diacids . . . . . . . 17 
RADIATION SOURCE AND DOSE RATE EFFECT ON SATURATED LINEAR

INELUENCE OF AIR AND FILM THICKNESS ON EFFECT OF IONIZING RADIATION ON INTRINSIC VISCOSITYY OF POLYTETRAMETHYTENE SEBACATTE

INFLUENCE OF CRYSTALLINITY AND ORIENTATION ON INTRINSIC VISCOSITY

OF IRRADIATED POLYTETRAMETHYIEENE SEBACATE

CHANGES IN COMPOSITION OF SOME POLYESTERS ON IRRADIATION . . . . . . 20

GRAFTING OF MONOMERS TO SATURATED LINEAR POLYESTERS . • . • • • • . • 22

CHANGES IN THE INFRARED SPECTRA OF POLYTETRAMETHYLENE SEBACATE

ON IRRADIATION . . . . . . . . . . . . . . . . . . . . 25

DIAGNOSTIC SAPONIFICATION . . . . . . . . . . . . . . 26

SUMMARY AND CONCLUSIONS

REFERENCES . . . . . . . . . . . . . . . . . . . . . 30

TABLES • . . . . . . . . . . . . . . . . . . . . . . 35

FIGURES . . . . . . . . . . . . . . . . . . . . . . . 52 
EFFECT OF IONIZING RADIATION ON A SERIES

\title{
OF SATURATED POLYESTERS
}

\author{
By G. F. D'Alelio, Roland Häberli, 1 \\ and George F. Pezdirtz²
}

\section{INIRODUCIION}

When a polymer is subjected to ionizing radiation, either a cross-Iinked or degraded polymer is obtained. In the past few years, the influence of such radiation on many polymers has been reported and reviewed in detail (refs. 1 and 2), and numerous attempts have been made to correlate the cross-linking or the degradation of the polymer to molecular weight (ref. 1), to the monomer and polymer structures (refs. 3 to 5), to the effect of oxygen (refs. 6 and 7), to the protection of aryl groups (ref. 8), to the linkages present in the polymer (refs. 5 and 9), and to other factors (pp. 49 to 60 of ref. 1).

To date, the literature in the field of polymer irradiation has dealt predominantly with the available addition polymers of commercial importance, even though there are many important condensation polymers. The number of condensation polymers studied has been limited. The most important classes of condensation polymers were not considered to undergo any notable improvement in properties under the influence of lonizing radiation (p. 173 of ref. I). The phenolic resins (ref. 10), as well as the melamine-formaldehyde and urea-formaldehyde resins (ref. 10) and polysulfide elastomers (refs. 11 to 13), are easily degraded by ionizing radiation. The polyamides (refs. 3, 9, and 10) and the polyurethanes (ref. 10) are cross-linked by irradiation with a decrease in some of their physical properties. Polyethylene terephthalate has received the most attention (refs. 3, 10, and 14 to 16) and appears to be more resistant to radiation than many other polymers. As a class of condensation polymers, the unsaturated polyesters have also been studied. (See ref. 11.) Charlesby and co-workers studied radiation reactions of unsaturated polyesters and also reported (ref. 17) that one saturated linear polyester did not change in solubility or viscosity after irradiation. These results are in marked contrast to the effects produced on unsaturated analogous structures, all of which cross-linked, and differ from the effects of radiation on addition polymers containing ester groups. The acrylate polymers, in which the ester groups are located in the side chains, belong to this latter class and are known to be cross-linked by ionizing radiation (refs. 11, 17, and 18).

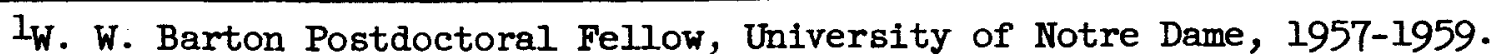
(Present address: Eidg. Institut fuer Reaktorforschung, Wirenlingen, Switzerland).

$2_{W}$. W. Barton Predoctoral Fellow, University of Notre Dame, 1956-1958. (Present address: NASA Langley Research Center, Hampton, Va.). 
There is no published detailed study on the effect of ionizing radiation on simple carboxylic esters, and the influence of side-chain ester groups in the acrylates cannot be considered as applicable directly to polymers having ester links in the backbone chain, as in the saturated linear polyesters. However, it may be concluded from a comparison of the polyacrylates (ref. 18) and polyethylene (ref. 19) that the ester group can act as an energy sink in stabilizing the polymer chain against scission as well as cross-linking.

Also, there have been no detailed publications on the effect of irradiation on the saturated polyesters or on related condensation polymers such as the polyamides of amino acids. This information would be invaluable in human welfare because living cells are composed primarily of proteins and nucleic acids. Little is known about how radiation reacts with protein polymers to produce mutation effects or cause destruction of tissue. The state of knowledge on polymer irradiation is still too meager to apply the results to such complicated polymers as proteins, but as the research is extended from simple to more complicated molecules, it may be possible eventually to understand the behavior of the proteins. Compared with the polymers found in living entities, the polyesters are relatively simple polymers, and for this reason, among others, a series of saturated linear polyesters were prepared and subjected to ionizing radiation.

The polymers used in this study are the polyesters of dihydric alcohols, $\mathrm{HO}-\mathrm{R}_{1}-\mathrm{OH}$, and dicarboxylic acids, $\mathrm{HOOC}-\mathrm{R}_{2}-\mathrm{COOH}$; they have in their structures as the repeating unit $-\mathrm{OC}-\mathrm{R}_{1}-\mathrm{COO}-\mathrm{R}_{2}-\mathrm{O}-$. As a class, these polyesters are well known and readily prepared. The information derived from the se studies could be extended readily to the polyesters derived from hydroxycarboxylic acids, which are not as well known and have the repeating unit $-0-\mathrm{R}_{1}-\mathrm{CO}$ - in their structures. An obvious extension of this class of polyesters, $-0-\mathrm{R}_{1}-\mathrm{CO}-$, are the polyamides of $\omega$-amino acids (which have the repeating unit $-{\stackrel{\mathrm{N}}{\mathrm{R}}-\mathrm{R}_{1}-\mathrm{CO}-}^{-})$. The proteins, $\left(\stackrel{\mathrm{R}}{\mathrm{N}-\mathrm{CR}_{2} \mathrm{CO}}\right)_{\mathrm{n}}$, are the first members of this latter series. The knowledge gained in studies of such polymers should be useful also in the "molecular engineering" ( ref. 20) of polymers for specific applications in space and other environments where ionizing radiation is prevalent, and in synthesizing polymers with specific cross-linking characteristics.

The saturated polyesters were chosen for this study because they could be readily prepared autocatalytically to any desired molecular weight. This characteristic afforded a means of correlating radiation effects with the molecular weights of the polymer. The fact that the polyesters could be prepared autocatalytically eliminates the possiblity of catalyst contamination, which could lead to misinterpretation of the effects of irradiation.

Since the pendant ester group has been shown to be an energy sink (ref. 18), it was desirable to investigate the effect of radiation on polymers which contain the ester group as an integral part of the polymer backbone. In order to determine the effect of this type of structure, it was necessary to consider 
polymer systems which could be prepared with a predetermined structure in the main chain. In polyesters, the structure of the polymer can be varied by the proper choice of the starting diol or the diacid, or both; thus, a convenient method for changing the nature of the $-R_{1}$ - and $-R_{2}$ - structures in the chain is afforded. If $-\mathrm{R}_{1}$ - and $-\mathrm{R}_{2}$ - are methylene, $-\mathrm{CH}_{2^{-}}$, groups, the ratio of the number of methylene groups to the number of carboxyl groups in the acid, or to the number of hydroxyl groups in the diol, or to the number of ester groups in the polymer can be varied at will. The effect of this variable has not yet been reported in the literature. In branched vinyl addition polymers, such as in polyethylene, an exact correlation of the branched structure with the crosslinking efficiency of irradiation is difficult to assess because of the random nature of the branching. In attempts to overcome this problem by copolymerizing a branch containing monomer, such as propylene, with a nonbranched monomer, such as ethylene, the same difficulties of interpretation would be encountered, because of the random combination of the monomers. However, polyesterification also affords a means of preparing a series of polymers of predetermined ordered branches along the chain by the proper selection of branched dicarboxylic acids or branched diols (e.g., methyl- and ethyl-substituted diaclds or diols). Also, the branch can be selected to act as a known energy sink as in the case where it is an aromatic ring (ref. 8). In using this approach, an appropriate series of polyesters of various molecular weights were synthesized and subjected to ionizing radiation. The changes in the polymers were observed by noting changes in the intrinsic viscosity, after first determining if the presence of oxygen influenced the results obtained. The effects of different radiation sources and dose-rate dependency were also studied. The studies were extended to the grafting monovinyl and divinyl monomers to determine their influence in modifying the cross-linking reaction.

The use of condensation polyesters offers other potential advantages over vinyl addition polymers with regard to chemical analysis of the irradiated polymers. It should be possible to hydrolyze the polyesters, and any new bonds formed by irradiation, if they are carbon-to-carbon bonds, would not be destroyed by the hydrolysis. The new molecules, which would be admixed with the regenerated initial diols and diacids, could then be identified or otherwise characterized. This property is in contrast to that of vinyl addition polymers whose main chain contains only carbon-to-carbon linkages. Since in most cases the new bonds formed on irradiating vinyl polymers are carbon-tocarbon bonds and the ruptures are random carbon-to-carbon scissions, a diagnostic degradation appears to be futile.

With the polyesters, three new types of molecules could result from the formation of a new bond between two chains: a tetracarboxylic acid, (A), a dihydroxy dicarboxylic acid, (B), and a tetrahydric alcohol, (C).

$$
\begin{aligned}
& \mathrm{HOOC}-\mathrm{R}_{1}-\mathrm{COOH} \\
& \mathrm{HOOC}-\mathrm{R}_{1}-\mathrm{COOH}
\end{aligned}
$$<smiles>O=[R2](O)C(=O)O</smiles>

(B)

$$
\begin{aligned}
& \text { HO- } \mathrm{R}_{2}-\mathrm{OH} \\
& \text { HO- } \mathrm{R}_{2}-\mathrm{OH}
\end{aligned}
$$


It becomes apparent that as the number of carbon atoms in the $R_{1}$ and $R_{2}$ groups increases, the number of possible isomers increases and complicates the characterization of the product. Irradiated polyethylene succinate would be an ideal polymer to subject to diagnostic saponification because only three compounds, neglecting optical isomers, are possible:

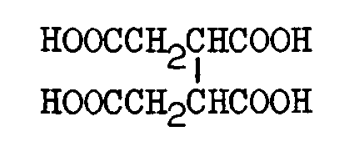

(Mol. wt. of 402)

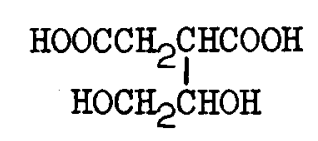

(Mol. wt. of 291)

\author{
$\mathrm{HOCH}_{2} \mathrm{CHOH}$
$\mathrm{HOCH}_{2} \mathrm{CHOH}$
}

(Mol. wt. of 178)

Unfortunately, it was found that polyethylene succinate does not cross-link upon irradiation, and for that reason, polytetramethylene sebacate was selected for a preliminary study.

\section{EXPERIMENTAL}

\section{REAGENTS AND POLYESTER SYNTHESES}

The reagents used in the present studies and their sources are given in table 1. The diacid and the diol in a 1:1.05 mole ratio were condensed by using a modification of Carothers procedure (refs. 21 and 22). Nitrogen was used as an inert atmosphere to prevent peroxide formation and other oxidation products. The polycondensations were performed initially at atmospheric pressure and, in the more advanced stages, at reduced pressures of 0.1 to $0.5 \mathrm{mil}-$ limeter $\mathrm{Hg}$ at temperatures in the range of $200^{\circ} \mathrm{C}$ to $250^{\circ} \mathrm{C}$ until the desired viscosity range was obtained. In this manner, the related polymers of approximately the same composition and of at least two different molecular weights were prepared. In most cases, four polymers of varying molecular weights were isolated. The polyesters that were prepared are given in tables 2 and 3 . The conditions under which the individual polymers of various initial intrinsic viscosity before irradiation were prepared are given in the footnotes in tables 4 to 38 . Table 2 gives the unsubstituted straight-chain polyesters, and table 3 gives their alkyl- and aryl-substituted polyesters, which, for the purposes of this paper, are considered as having branches which may influence the effects due to ionizing radiation.

\section{IRRADIATION OF POLYESTERS}

The irradiation of the polyesters was performed in most cases with use of the ARCO Mark I microwave linear accelerator at the Applied Radiation Corporation, Walnut Creek, California, and at the ARCO Midwest Radiation facilities in Rockford, Illinois. This accelerator operates at a beam energy of $8 \mathrm{MeV}$ and 
can completely penetrate 4 centimeters of unit-density material. The molten polymer samples were cast into 1.5-centimeter glass vials in a deoxygenated nitrogen atmosphere and sealed in this condition. The beam width was about 10 centimeters; the average beam power during irradiation was 530 watts with 180 pulses per second, with a pulse length of 6 microseconds, and with a peak current of 50 milliamperes. The sample vials were placed on a turntable of 13 feet in circumference, which rotated at $7 \mathrm{rpm}$ under a vertically mounted wave guide. Air from cooling blowers was directed at the sample vials to maintain the temperature of the samples at about $50^{\circ} \mathrm{C}$. Since, at the dose rate obtained in this accelerator, heat is generated within the sample, those polymers which melt below $50^{\circ} \mathrm{C}$ softened or melted. During periodic inspection of the sample vials, gas bubbles were noted in some of the molten polymers as a result of the evolution of gaseous irradiation byproducts. Dosimetry was based on the change in the optical density of cobalt glass, which had been standardized against the primary standard of calorimetry (ref. 23). In order to determine the effect of dose rate and the influence of the nature of the source of ionizing radiation, some of the polymers were irradiated by using a $2 \mathrm{MeV}$ Van de Graaff electron accelerator of the Radiation Laboratory, University of Notre Dame, at 25, 50, and 100 microamperes and an underground 1200-curie cobalt 60 source (ref. 24 ).

\section{INTRINSIC VISCOSITIES}

Freshly distilled chloroform was used as the solvent for measuring the intrinsic viscosities. The polymer concentrations were $0.8,0.4$, and 0.2 gram per 100 milliliters, and the intrinsic viscosities [ ] were calculated from the relationship $[\eta]=\lim _{C \rightarrow 0}\left(\eta_{\mathrm{sp}} / \mathrm{C}\right)$. (See ref. 25.) The measurements of the intrinsic viscosities were made with an Ubbelohde viscometer in a constant-temperature bath at $25^{\circ} \mathrm{C} \pm 0.05^{\circ}$.

\section{CORRETATION OF INTRINSIC VISCOSITY WITH ABSORBED RADIATION DOSE}

The effects of lonizing radiation on the intrinsic viscosity of the respective polymers are summarized in tables 4 to 38 and graphically presented in figures 1 to 35 . The term gel, which appears in both the tables and figures, refers to those polyesters which have been converted from linear soluable polymers to three-dimensional polymers which were insoluble in boiling chloroform as a result of cross-linking.

\section{EFFECT OF DOSE RATIE AND SOURCE OF IONIZING}

\section{RADIATION ON INTRINSIC VISCOSITY}

Three films of polytetramethylene sebacate having thicknesses of $10 \mathrm{milli}$ meters were introduced in glass tubes, and the tubes were then evacuated for 
24 hours by means of a mercury diffusion pump to a pressure of $1 \times 10^{-6} \mathrm{~mm} \mathrm{Hg}$, sealed, and subjected to irradiation by the cobalt 60 source, the Van de Graaff, and the ARCO linear accelerator to a total dose of 6 megareps. The dose rate varied from 1 megarep per hour for the cobalt 60 in the location in which the sample was placed to dose rates of about 1400 megareps per minute in the ARCO accelerator during the pulses of actual irradiation in the sample. The data on the changes in the intrinsic viscosity of the polymer are given in table 39 and shown graphically in figure 36 .

\title{
INFLUENCE OF AIR AND FILM THICKNESS ON
}

\author{
EFFECTS OF IONIZING RADIATION
}

Six films of polytetramethylene sebacate of thicknesses varying from 0.1 to 2.0 millimeters were introduced into glass tubes, and the tubes were then evacuated at room temperature for 72 hours at a pressure of $1 \times 10^{-7} \mathrm{~mm} \mathrm{Hg}$ to remove air and traces of volatile matter. Air, which had been filtered through glass wool, was admitted to two of the tubes to a pressure of $2 \mathrm{~mm} \mathrm{Hg}$, and to three of the tubes to a pressure of $760 \mathrm{~mm} \mathrm{Hg}$; all tubes were then sealed and irradiated within a dose range of 2 to 6 megareps. The weight of the polymer was $0.05 \mathrm{gram}$, and the volume of the tubes was 50 milliliters. The influence of air and film thickness on the radiation-induced changes in the intrinsic viscosity is given in table 40 and graphically shown in figure 37.

\section{INFLUENCE OF ORIENTATION ON EFFECT OF IONIZING RADIATION}

Polytetramethylene sebacate $([\eta]=0.358)$, which exhibits marked crystallinity, was melt-spun to monofilaments of about 0.1 millimeter. Parts of these monofilaments were stretched at room temperature, to 3 times their original length, and annealed at $60^{\circ} \mathrm{C}$ for 8 hours after which they exhibited marked birefringence under cross Nicol prisms. One-tenth-gram samples of the unstretched and stretched filaments were placed in 50-milliliter glass tubes, and the tubes were then evacuated at a pressure of $1 \times 10-7 \mathrm{~mm} \mathrm{Hg}$ for 72 hours after which they were irradiated at $25^{\circ} \mathrm{C}$ with dosages up to 13 megareps. Another set of tubes was heated to $80^{\circ} \mathrm{C}$ before and during the irradiation so that the polymer was in the amorphous state. The intrinsic viscosities before and after irradiation were measured. The data are summarized in table 41 and shown graphically in figure 38 .

\section{EFFENT OF POSTHEATING ON IRRADIATED POLYTETRAMETHYLENE SEBACATE}

One-tenth-gram samples of irradiated polytetramethylene sebacate monofilaments $([\eta]=0.358$ ) were sealed in 50-milliliter tubes at a pressure of $1 \times 10^{-7} \mathrm{~mm} \mathrm{Hg}$ after the tubes had been evacuated for 72 hours. The samples were then subjected to a 3-megarep dose of irradiation, which is below that 
found to produce a gel. The irradiated monofilaments, while still in the sealed tubes, were heated for various periods of time at $68^{\circ} \mathrm{C}$, which is the melting point of the polymer. Intrinsic viscosities were measured before and after the heating periods, and the results are given in table 42 and graphically presented in figure 39.

\title{
CEANGES IN ELEMENTAL COMPOSITIONS OF POLYMER ON IRRADIATION
}

\author{
Effect of Thickness on Loss of Weight
}

of Irradiated Sample

Films of polytetramethylene sebacate having thicknesses of $0.25,0.50$, and 0.75 millimeter were placed in 25-milliliter tubes, evacuated at a pressure of $1 \times 10^{-7} \mathrm{~mm} \mathrm{Hg}$ for 8 hours, and then irradiated. The weight of the films was approximately 0.1 gram. After irradiation the tubes were opened and the films were weighed. The films were then degassed at room temperature at $1 \times 10^{-7} \mathrm{~mm} \mathrm{Hg}$ for 48 to 72 hours to constant weight. The percent weight losses for the polytetramethylene sebacate films are summarized in table 43.

\section{Elemental Analysis of Polyesters Before and After Irradiation}

Two-gram samples of 0.25 -millimeter films of polytetramethylene sebacate and polyethylene succinate were sealed in 25-milliliter tubes and evacuated at $1 \times 10^{-7} \mathrm{~mm} \mathrm{Hg}$ for 24 hours, irradiated, and then heated to destroy trapped radicals. Similar unsealed samples were irradiated while exposed to air. Analyses for carbon, hydrogen, and oxygen were made by Midwest Microlab, Inc., Indianapolis, Indiana, on the samples of the polyesters before and after irradiation, and the results obtained are summarized in table 44.

\section{Analysis of Gases Resulting From Irradiation of Polyesters}

A sample of the polyester was introduced into a 25-milliliter irradiation cell sealed with a vacuum stopcock, evacuated at $1 \times 10^{-7} \mathrm{~mm} \mathrm{Hg}$ for 12 hours, and then irradiated to the dosages indicated in table 45. After irradiation, the cell was cooled to within the range of $-8^{\circ} \mathrm{C}$ to $-10^{\circ} \mathrm{C}$ for 2 hours to condense any liquid products. The gaseous products were then allowed to expand at room temperature from the irradiation cell into a 300-milliliter collection bulb previously evacuated to $10-6 \mathrm{~mm} \mathrm{Hg}$, and a mass spectrographic analysis was performed by using a Consolidated Engineering Corp. type 21-103A spectrometer. The data in mole percent are reported for polyethylene succinate, polytetramethylene sebacate, and polydecamethylene sebacate in table 45, along with the data of other compounds such as polymethyl methacrylate (ref. 26), caprylic acid, sebacic acid, and cetyl palmitate taken from the literature (refs. 27 and 28). 
The polyester was melted at temperatures from $60^{\circ} \mathrm{C}$ to $65^{\circ} \mathrm{C}$ in an inert atmosphere in a dry box, and a weighed amount of monomeric redistilled styrene or divinylbenzene was stirred into the melt until it appeared to be homogeneous; then, the mixture was transferred to an irradiation cell and immediately cooled in a dry-ice-acetone mixture. The irradiation cell and contents were evacuated for 2 hours at $10^{-7} \mathrm{~mm} \mathrm{Hg}$ while cooled in liquid nitrogen. The cell was then sealed and exposed to irradiation, and the changes in a number of properties after radiation at the specific doses were measured.

\section{Effect of Irradiation on Intrinsic Viscosity of}

\section{Mixtures of Polyesters and Divinylbenzene}

The intrinsic viscosities of irradiated mixtures of polytetramethylene sebacate and divinylbenzenes at dosages below the gelation doses are given in table 46 and graphically presented in figure 40. The changes in the viscosities of mixtures of divinylbenzene and polyethylene sebacate after irradiation are qualitatively and quantitatively so similar to viscosity changes of the tetramethylene ester that they do not need to be reported separately. The divinylbenzene used in these experiments contained 50.2-percent mixed divinylbenzenes and 49.8-percent mixed ethyl vinylbenzenes, and 2 grams of the mixture were used when 1 gram of divinylbenzene was required. In one case (table 47), pure p-divinylbenzene was used.

\section{Effect of Irradiation on Solubility of a Mixture of}

\section{Polyester and Divinylbenzene or Styrene}

The mixtures were prepared as described previously and exposed to irradiation for the period of time indicated. The sample was then submitted to extraction. A sample weighing from 0.1 to 0.2 gram was placed in a Soxhlet microextractor (thimble volume about 7 milliliters) and continuously extracted with chloroform for 24 hours. The extracted sample was then dried to constant weight in a vacuum oven at $40^{\circ} \mathrm{C}$, and the amount extracted was considered as the soluble portion of the mixture. The solubility data for irradiated mixtures of divinylbenzene and polytetramethylene sebacate are given in table 47 and graphically presented in figure 4I; for mixtures of polytetramethylene sebacate and styrene, in table 48 and figure 42; and for mixtures of polyethylene succinate and divinylbenzene, in table 49 and figure 43.

\section{Swelling Index of Irradiated Polymers}

A 0.050 -gram sample of an irradiated polymer was immersed in 50 milliliters of chloroform at room temperature until equilibrium was reached and no further 
volume change was noted in the swollen polymer. The time required varied from 4 to 8 days. The swollen polymer was then separated from excess solvent and weighed in a tightly closed weighing bottle. The swelling index was calculated by using the formula, $\left(W_{f}-W_{i}\right) / W_{1}$, where $W_{f}$ is the weight of the swollen polymer and $W_{1}$ is the initial weight of the polymer before swelling. The lower the swelling index, the higher is the extent of cross-linking. The data for the mixture of polytetramethylene sebacate and divinylbenzene are summarized in table 50 and represented graphically in figure 44; the data for the mixture of polyethylene succinate and divinylbenzene are given in table 49.

\section{INFRARED SPECTRA}

A Perkin-Elmer double-beam infrared spectrophotometer, Model 2l, with a $\mathrm{NaCl}$ prism was used to obtain the spectral data. Operating conditions were selected to give a compromise between resolution and noise level. The polyester samples used were prepared in film form by casting solutions of the polymer in chloroform on new glass plates. The solvent was then allowed to evaporate at room temperature for 24 hours, after which the samples were heat-treated in an oven from $63^{\circ} \mathrm{C}$ to $64^{\circ} \mathrm{C}$ for 8 to 10 hours. The film thicknesses used ranged from 0.8 to 1.8 millimeters. The films were removed from the glass and mounted on small cardboard frames with the film being the "window" of the frame. In order to remove volatiles from the samples, they were evacuated at $10^{-6} \mathrm{~mm} \mathrm{Hg}$ for 8 to 10 hours at room temperature, and the spectra were recorded before and after irradiation in vacuo $\left(10^{-6} \mathrm{~mm} \mathrm{Hg}\right)$ and in air.

Polytetramethylene sebacate was irradiated to doses of 50, 150, and 250 megareps, and the spectra recorded before and after irradiation were compared. Complete information required to interpret the spectra of saturated aliphatic polyesters does not exist in the published literature. Therefore, an additional study was undertaken at the University of Notre Dame on the spectra of this class of polyesters, and assignments of as many of the absorption bands as possible were made with the help of published data on related compounds and other polymers.

\section{DIAGNOSTIC SAPONIFICATION OF IRRADIATED POLYTETRAMETHYLENE SEBACATE}

The polytetramethylene sebacate $([\eta]=0.420)$ was prepared from 101 grams of sebacic acid ( 0.5 mole) and 45.9 grams of butanediol-1,4 (0.51 mole) by reaction at $250^{\circ} \mathrm{C}$ for 5 hours at 1 atmosphere, then at $270^{\circ} \mathrm{C}$ for 72 hours at $0.1 \mathrm{~mm} \mathrm{Hg}$. Neutralization Equivalent (N.E.) of sebacic acid was approximately 101 (206 milliliters of $0.4808 \mathrm{~N} \mathrm{KOH}=100.96$ for a mol. wt. of 201.92). For irradiation, part of the molten polyester was cast under nitrogen into a thin rectangular sheet about $350 \mathrm{millimeters} \mathrm{thick,} \mathrm{sealed} \mathrm{under} \mathrm{nitrogen} \mathrm{in} \mathrm{a} \mathrm{double} \mathrm{layer} \mathrm{of}$ 1-millimeter-thick aluminum foil, and irradiated. The dose rate was 1.6 megareps per minute; the sample was maintained at about room temperature by contact with cooled metal blocks. The total dose was 250 megareps, and the swelling index, $\left(w_{f}-w_{i}\right) / w_{i}$, was 0.76 . Samples of the polymer before and after irradiation were saponified by the following procedures. 
The unirradiated polymer was cut into small pieces, and 25.6 grams were added to 42 grams of $\mathrm{KOH}$ in 100 milliliters of 50 -percent aqueous ethanol and refluxed in a nitrogen atmosphere for 72 hours. The homogeneous saponified mixture was diluted with 500 milliliters of distilled water, filtered, and passed through a l-meter column of Dowex 50 cation exchange resin. The column contained 2.5-mole equivalents of the resin in the hydrogen form. Sodium cobalt-nitrate was used to test the resin-treated solution A for the presence of potassium ions. Four passes through the column were required before a potassium-free solution was obtained. Between passes, the column was allowed to drain and was then refilled with water, allowed to stand for 1 hour, and drained again. The drainings and washings were added to solution A. The washing was repeated three times; the column was then regenerated with mixtures of 50-percent water and 50-percent concentrated $\mathrm{HCl}$, and washed until free of chloride ions. Solution A containing the carboxylic acids and the polyols was then concentrated at a pressure of $15 \mathrm{~mm} \mathrm{Hg}$ at a temperature from $25^{\circ} \mathrm{C}$ to $30^{\circ} \mathrm{C}$. When the volume was reduced to 200 milliliters, the acids precipitated and were then separated by filtration and washed by cold water. The washings and filtrate were combined to form solution $B$. In order to remove the last traces of acids, solution $B$ was passed through a column of Dowex 2 anion ion exchange resin, and the deacidified solution $C$ was collected. The column was filled with distilled water, allowed to stand for 2 hours, and drained. The washings were repeated three times and, then, were added to solution $\mathrm{C}$. The carboxylic acids were eluted from the anion exchange resin with 15-percent $\mathrm{HCl}$, and the column was filled with distilled water twice and allowed to stand for 2 hours. The eludate and the washings were combined and then evaporated under reduced pressure ( $15 \mathrm{~mm} \mathrm{Hg}$ ), and the solid carboxylic acids were combined with the acids previously separated and dried in vacuo at $50^{\circ} \mathrm{C}$ to a constant weight of 19.9 grams which is 98.5 percent of theory (N.E. = 101, recrystalized m.p. of $133^{\circ} \mathrm{C}$ ).

The deacidified solution $\mathrm{C}$ was distilled in an 18-inch fractionating column to remove water and low boiling materials, and then to isslate the butanediol, which was recovered in a yield of 8.92 grams which is 99.1 percent of theory (b.p. of $229^{\circ}$ to $230^{\circ} \mathrm{C}, \mathrm{n}_{\mathrm{D}}^{25}=1.443$; lit. b.p. of $\left.230^{\circ} \mathrm{C}, \mathrm{n}_{\mathrm{D}}^{25}=1.446\right)$.

An attempt was made to saponify 25.6 grams of the irradiated polymers cut into small pieces with the same $\mathrm{KOH}-\mathrm{H}_{2} \mathrm{O}-\mathrm{CH}_{3} \mathrm{OH}$ mixture used for the unirradiated sample, and very little saponification occurred in 30 hours; only surface pitting was evident on the polymer, and the saponification under these conditions was discontinued. Instead, the polymer was added to a solution of 42 grams of $\mathrm{KOH}$ in 200 milliliters of water and heated to $160^{\circ} \mathrm{C}$ in an autoclave for 48 hours. This process resulted in a homogeneous solution which was diluted, when cool, with 500 milliliters of distilled water, filtered, and treated with ion exchange resins, similarly to the saponified unirradiated polyesters. The recovered weight of tetramethylene glycol was 8.856 grams which is 98.4 percent of theory (b.p. of $229^{\circ}$ to $230^{\circ} \mathrm{C}, \mathrm{n}_{\mathrm{D}}^{25}=1.444$ ). The weight of the polycarboxylic acids (m.p. of $130.2^{\circ} \mathrm{C}$ ), was 19.81 grams which is 98.1 percent of theory. The neutralization equivalent ( 19.28 milliliters of $0.5102 \mathrm{~N} \mathrm{KOH}$ ) was 101.65, which corresponds to a molecular weight of 203.3 for a dicarbocyclic 
acid, 304.95 for a tricarboxylic acid, and 406.6 for a tetracarboxylic acid, or a mixture of 99.35 -percent sebacic acid and 0.65 -percent disebacic acid. The carboxylic acid fraction was recrystallized from water and dried; the recovered weight was 18.73 grams (m.p. of $133^{\circ} \mathrm{C}$, N.E. = 101). The filtrate was evaporated to dryness yielding 1.068 grams. (N.E. $=106.8$, which corresponds to a mixture of 93.5-percent sebacic acid and 6.35-percent disebacic acid. The Hydroxyl Number was too small to measure.)

\section{DISCUSSION}

\section{EFFECT OF IRRADIATION ON INIRINSIC VISCOSITY}

OF SATURATED LINEAR POLYESTERS

When a polymer is subjected to ionizing radiation, either of two ultimate effects may result: (1) the cross-linking of the polymer chains observable first by an increase in molecular weight (or intrinsic viscosity), and, with increased radiation dose, by the formation of an insoluble network or gel, or (2) degradation as a result of scissions in the polymer chain producing a decrease in its intrinsic viscosity. Both processes occur simultaneously in many polymers, and the final observable effect depends on the ratio of the rates of the cross-linking reaction $\alpha$ to the scission reaction $\beta$ in the specific polymer (pp. 80-83 of ref. 1). In the polyesters used in these studies, it would be expected that the cross-linking reaction $\alpha$ would occur by the coupling of (a) radicals formed on the carbon atoms in the skeleton of the diol or the diacid, - $\dot{\mathrm{C}} \mathrm{R}-$, or (b) vinylene groups, $-\mathrm{CH}=\mathrm{CH}-$, generated in the polymer; whereas, the scission reaction $\beta$ would be expected to occur within the ester moiety, and radicals of two types would result:

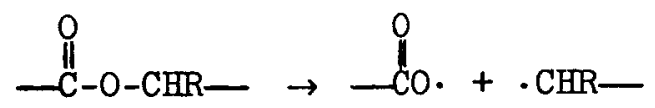

and<smiles>[R]O[O+][C+](C)C(=O)OC=[R]OC(C)=O</smiles>

In these studies, an effort was made to determine the location and nature of both the cross-linking and scission reactions.

\section{Straight-Chain Polyesters}

Ethylene glycol polyesters. - In general, the ethylene glycol polyesters were found to undergo moderate degradation with increasing doses up to 100 megareps. (See tables 4 to 7 and figs. 1 to 4.) The exception to this trend is found in the higher molecular weight polymers of polyethylene azelate and 
polyethylene sebacate. (Compare plots B and D in figs. 3 and 4 , respectively.) In both of these cases, there was an initial decrease in intrinsic viscosity at low irradiation doses (indicating a predominance of the scission reaction), which was followed by an increase in intrinsic viscosity with increased radiation. The polymer finally reached the cross-linked gel stage below the 50-megarep range. This phenomenon of initial degradation followed by final gelation is rather unusual (refs. 29 to 31), and there are only a few instances in which it has been reported (ref. 32).

Saito (refs. 29 to 31) has developed a theory that can be used to calculate the changes in intrinsic viscosity when a polymer is subjected to high-energy radiation. This theory was extended by Inokuti (refs. 33 and 34 ) who demonstrated that, if the molecular weight distribution is sufficiently broad, the intrinsic viscosity can at first decrease in certain instances, even if it reaches infinity at the gel point. At high extents of reaction in condensation polymers, the weight distribution, as in the case of these polymers where $[\eta]>0.4$, is very broad (refs. 35 and 36). Inokuti (refs. 33 and 34 ) concluded that this phenomenon also depends somewhat on the relative importance of the cross-linking and degradation reactions for specific polymers, that is, where the probability of cross-linking of a segment per unit of absorbed radiation is less than four times the probability of degradation in the same segment. It is apparent in the succinates and adipates of ethylene glycol (figs. I and 2) that the probability of degradation is very high and they fail to cross-link. This observation is also true of the lower molecular weight azelate and sebacate esters (figs. 3 and 4). Since their corresponding high molecular polyesters cross-link, it may be concluded that the $\alpha / \beta$ ratio has changed by the operation of a "cage effect" ( ref. 37), a concept which involves the recombination of initial radicals before they can diffuse out of an "active cage" and undergo elsewhere reactions other than recombination. A high intrinsic viscosity would be expected to supply such a "cage" for the glycol polyesters. Yet, it is interesting to note that when polyethylene succinate of $[\eta]>0.6$ is irradiated, cross-linking did not occur, even with increasing doses up to 200 megareps. Compared with the azelates and sebacates, the succinates and adipates are more difficult to draw into fibers and, in the solid state, are less crystalline (refs. 38 and 39), which indicates that crystalline regions act as effective cages. Since the low and high molecular weight polyethylene succinates do not cross-link (whereas the higher esters such as the adipates show an upward slope at 100 megareps, with a tendency to cross-link, and the azelates and sebacates do cross-link), the effect of the stmucture of the dicarboxylic in changing the ratio of cross-linking reaction to scission reaction becomes apparent in increasing the cage effect by increasing crystallinity.

This phenomenon does not imply that a viscosity cage effect may not also be simultaneously operative as may be observed in the low molecular weight azelates and sebacates and in the highly crystalline polyesters such as in the trimethylene, tetramethylene, and pentamethylene diol esters.

Trimethylene diol polyesters. - The trimethylene diol polyesters are more resistant to overall degradation than their corresponding ethylene glycol esters, as evidenced in a comparison of figure 1 with figure 5 for the succinates. Polytrimethylene succinate of low molecular weight is not cross-linked on irradiation (plot $\mathrm{A}$, fig. 5), which is attributable to a negligible viscosity 
cage effect. In contrast, its higher molecular polymers cross-link readily (plots $B$ and $C$, fig. 5) as a result of a cage effect manifested at an intrinsic viscosity of at least about 0.2 . The Inokuti phenomenon is apparent in plot B, figure 5. As the number of methylene groups is increased in the dicarboxylic acid portion of the trimethylene diol polyesters from the succinates to the adipates and the sebacates, this minimal value of about 0.2 for the intrinsic viscosity is maintained. There is not a distinct difference in the dosage at which gel formation occurs for the polytrimethylene succinate and sebacate, both of which are crystalline polymers; whereas, for the corresponding glycol esters, wherein the crystallinity in the succinate is negligible, the dosages at whtch gel formation occurs are quite different.

Tetramethylene diol and higher homologue polyesters.- Cross-linking is the predominating observable effect of irradiation on the polyesters of tetramethylene diol, pentamethylene diol, and decamethylene diol (figs. 8 to 15), all of which exhibit the viscosity cage effect; however, they fail to cross-iink below a certain low value of intrinsic viscosity, which is lowest for polydecamethylene sebacate, which has 10 methylenes in its diol and is highly crystalline.

If the molecular weight is sufficiently high in the saturated linear polyesters, the segment structure

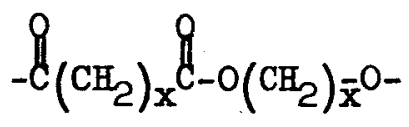

is the primary factor responsible for the direction of the overall radiation reaction. The two reactants, which comprise the segment, namely, the diol and the diacid, do not influence the radiation reaction to the same extent. Variation of the diol structure has a more noticeable effect on the direction of the radiation reaction than does the variation in the diacid. As the number of methylene groups in the diol increases from 2 to 10, the major observable effect of irradiation changes from degradation to cross-linking. An increase in the number of methylenes in the diacid has little apparent influence on the reaction direction. These effects may be interpreted as resulting from (a) more frequent main chain ruptures occurring in the diol portion between the ester bonds, particularly, when the segment contains only a few methylene groups and (b) the prevalence of the cross-linking reaction within the diacid portion. Stabilization of the diol ester bonds would be expected to favor the overall effect of the irradiation reaction toward cross-linking, whereas weakening of the bonds would favor degradation. The resonance structures of the polyester segments

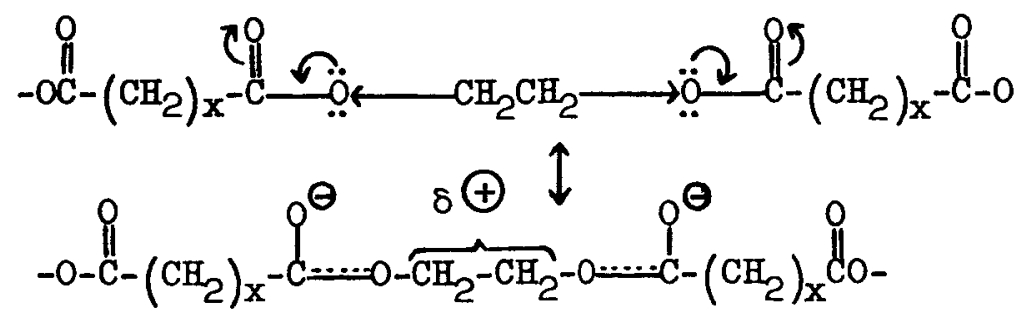

lend some support to this concept. 
The electron withdrawing effect of the carbonyl group pulls on the partially mobile electron of the acyl oxygen which in turn weakens the $\mathrm{C}-\mathrm{O}$ and $\mathrm{C}-\mathrm{C}$ bonds in the diol portion of the segment. Thus, when irradiation ionization or excitation occurs in these partially weakened bonds, a scission occurs. The weakening of these bonds appears to be of sufficient magnitude only where the two ester groups operate through a few methylene groups. This condition is fulfilled in the polyesters of dimethylene diol and to a lesser degree in trimethylene diol polyesters.

The presence of four methylene groups in the diol comer would isolate the electron withdrawing ester groups sufficiently to make any weakening of main chain bonds ineffective. This decrease in the scission reaction, even if the cross-linking reaction, which appears to occur mainly within the diacid component, is constant, increases the $\alpha / \beta$ ratio, and thereby, the cross-linking effect dominates.

It also would be expected that if the diol component is responsible for the scission reaction, a large increase in the number of methylene groups in the diacid would be required before cross-linking occurs easily; whereas, if the diol fragment is stabilized in some fashion, a smaller number of methylene groups would be required to attain the same end effect. These relationships are found in the saturated straight-chain polyesters discussed previously.

\section{Branched Diol Polyesters}

Methylethylene diol polyesters.- Cross-linking was the major effect of irradiation in the branched polyesters studied which were prepared from l-methylethylene glycol. Qualitatively, the efficiency of cross-linking was independent of the diacid structure. Gelation occurred at relatively low doses, usually less than 25 megareps, for the polyesters studied which had initial intrinsic viscosities close to 0.2 . This phenomenon indicates the existence of a viscosity cage effect. The behavior of these branched polyesters (figs. 16 to 19) should be contrasted to the respective linear polyesters based on ethylene glycol (figs. 1 to 4). The former cross-link whereas the latter degrade under ionizing radiation. The following structural formulas illustrate that the two groups differ only by a methyl branch in the diol comer:

$$
-\mathrm{CH}_{2}-\mathrm{CH}_{2}-\mathrm{OCO}-\left(\mathrm{CH}_{2}\right) x^{-\mathrm{OCO}-}
$$

Polyesters of ethylene glycol<smiles>CCC(C)CCC(C)OC(=O)[O-]</smiles>

Polyesters of 1-methylethylene glycol

The results shown in figures 1 to 4 and 16 to 19 indicate that the introduction of a single methyl group as a branch modifies the $\alpha / \beta$ ratio so that cross-linking is the favored end result. This result may be due to an increase in the cross-linking reaction by the formation of radicals in the methyl branch, resulting in radical cross-linking due to favorable distance relationships; thus, 


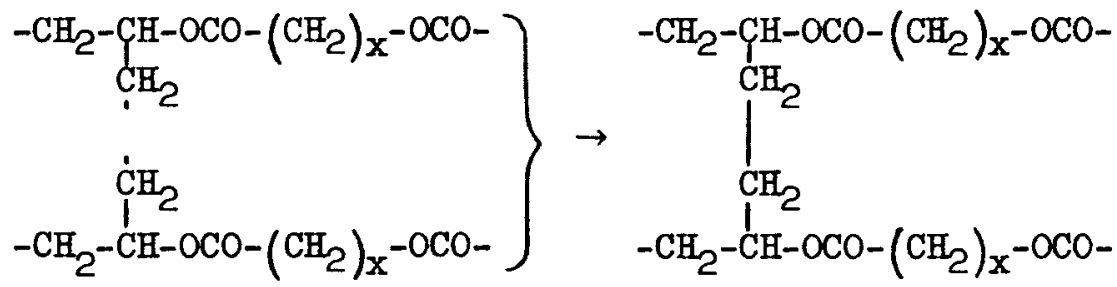

Alternately, the $\alpha / \beta$ ratio may be favored by a reduction in the scission reaction occurring in the ester group. Possibly, the methyl branch would supply electrons to the partially deficient carbon atom (alpha to the electron withdrawing ester group) by hydrogen bonding to the partially negative carbonyl oxygen through the formation of a six-membered ring, as shown in the following hyperconjugated structure. For simplicity, the complete segment is not shown.

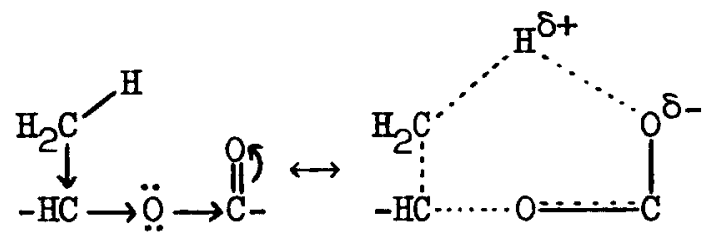

Of the two mechanisms, the radical formation on the branch, which is responsible for the increase in the $\alpha / \beta$ ratio, is considered to be the least favorable, although it undoubtedly exists to some extent. If radicals are formed on the methyl branches and these radicals are responsible for the increase in the overall cross-linking reactions in these polymers, a similar increased effect should be observable in the polyesters of 2,2-dimethyltrimethylene diol (figs. 20 to 23) as compared with the unbranched trimethylene diol esters (figs. 5 to 7). However, such an effect was not observed.

Similarly, radicals of methyl branches should also be formed and be effective in promoting cross-linking when methyl groups are present in the diacid, whereas the contrary effect, increased scission, is observed in the comparisons of unbranched polypentamethylene succinate ( $\mathrm{fig} . \mathrm{ll}$ ) and polypentamethylene adipate ( $\mathrm{fig}$. 12) with polypentamethylene-2-methyl succinate (fig. 35). The viscosity cage effect is evident in these 1-methylethylene diol polyesters, but since the methyl substitution greatly reduces the crystallinity of the polymers, none of the polyesters prepared exhibited a crystallinity cage effect.

2,2-dimethyltrimethylene diol polyesters.- The polyesters of 2,2-dimethyltrimethylene diol cross-link under irradiation and exhibit a viscosity cage effect (figs. 21 to 23). The location of the methyl groups in the 2 position in the diol excludes the formation of a six-member ring postulated for the l-methyldimethylene diol polyesters and, therefore, may be excluded from consideration as a stabilizing factor. The influence of dimethyl substitution in these esters must be considered in a comparison with the unbranched trimethylene diol polymers (figs. 5 to 7 ) or with the unbranched pentamethylene diol polyesters (figs. 11 to 14) which have a total of 5 carbon atoms in the diol. In general, it may be concluded that little if any contribution is made to the cross-Iinking end result by these methyl groups, and therefore, there is a minor, if any, production of radicals on the branched methyl groups. In fact, 
cross-linking is poorer in the poly-2,2-dimethyltrimethylene succinate (fig. 20) than in the corresponding polytrimethylene succinate (fig. 5), which probably reflects a reduction in the amount of crystallinity; whereas, the corresponding adipates (figs. 6 and 21 ) and sebacates (figs. 7 and 23) exhibit the overall cross-linking reaction within the same order of magnitude.

2,2-diethyltrimethylene diol polyesters.- The 2,2-diethyltrimethylene diol polyesters were made to determine whether or not an increase in the length of the branches from methyl to ethyl would change their behavior under irradiation. The ethyl branches are located on the 2-carbon atom in the diol and, similarly to the methyl substitution in the same position, could only form seven- or eight-membered rings; thereby, the concept of scission stabilization through the formation of a six-membered ring is excluded. The polyester of the 2,2-diethyltrimethylene diols (figs. 24 to 27) cross-links more readily than the corresponaing 2,2-dimethyl derivatives (figs. 20 to 23) with gelation occurring generally at lower intrinslc viscosities even though the linear disorder is increased and the crystallinity thereby decreased. If ring formation is excluded, since this would require the formation of seven-membered rings, the slight increase in the cross-linking reaction may be attributable to bond formation through some function of the ethyl branches; this would require elther radical formation or its disproportionation to a pendant vinylidene group which, in turn, would form cross-links.

3-methylpentamethylene diol polyesters.- In the 3-methylpentamethylene diol polyesters, the methyl branch is on the 3-carbon atom and thus differs from the previously discussed branched diols whose branches were located on the 1-carbon and 2-carbon atoms. From a comparison of these polyesters (figs. 28 to 31) with the corresponding pentamethylene diol esters (figs. 11 to 14), it is observed that the methyl substitution contributes little, if anything, to the cross-linking reaction.

The results for the polyesters considered thus far indicate that the main scission reactions occur in the ester linkages and that the major cross-linking reactions occur in the diacid component in the polyester whether or not the diol is linear or branched. Therefore, it was interesting to irradiate a number of polyesters derived from branched diacids with both unbranched and branched diols and to observe the effect of irradiation on the intrinsic viscosity of such polymers.

\section{Polyesters of Branched Dicarboxylic Acids}

Polypentamethylene-2,3-diphenyl succinate.- There was no major observable change in the intrinsic viscosity of polypentamethylene-2,3-diphenyl succinate with irradiation ( $\mathrm{fig}$. 32) for samples having initial intrinsic viscosities corresponding closely to those of polypentamethylene succinate ( $\mathrm{fig}$. Il), which cross-linked very readily. In fact, there is slight evidence of degradation in the slope of the curves in figure 32. Since no cross-linking occurs, it might be concluded that the hydrogen on the alpha carbon atom in the diacid undoubtedly participates in the cross-linking reaction since the corresponding unsubstituted succinate polyester does cross-link. Such an argument may not be valid since this failure to cross-link might have been expected because of 
the benzene ring which has been shown previously (ref. 5) to act as an energysink and to offer resistance to changes in polymers. It is interesting to note that in these polyesters, the protective nature of the phenyl group is capable of operating through the ester linkages in a fashion similar to the protection to aryl-substituted paraffins over 12 carbon atoms (ref. 5).

Polypentamethylene-2-methyl succinate.- In order to eliminate the energysink effect present in the diphenyl succinic acld, the corresponding 2-methyl succinate polyester, having the same viscosity ranges (fig. 35) in which the polypentamethylene succinate cross-links readily, was prepared. No crosslinking was observable in the polymer with an initial intrinsic viscosity of 0.146 , and only a slight increase in viscosity was observed for the polymer having an initial intrinsic viscosity of 0.184 after 50 megareps of irradiation.

This slight change in viscosity may be the result of a molecular weight redistribution brought about by rearrangements resulting from scissionrecombination reactions extended over long periods of time. The substitution of the methyl group for hydrogen in succinic acid, which greatly reduces or eliminates cross-linking, indicates that the alpha hydrogen in the dicarboxylic acid plays an important role in the cross-linking reaction.

\section{Polyesters of Branched Diols and Branched Diacids}

Two polyesters which have branches in both the diol and in the dicarboxylic component of the segmer were prepared. The polymer poly-3-methylpentamethylene3-methyl adipate failed to cross-link when irradiated and showed evidence of degradation ( $\mathrm{f} 1 \mathrm{~g}$. 33) in contrast to poly-3-methylpentamethylene adipate (fig. 29) which does cross-link. This behavior indicates that methyl substitution on the beta carbon atom of the dicarboxylic acid retards cross-linking and is similar to the effect of methyl substitution on the alpha carbon atom (fig. 35). The result with poly-3-methylpentamethylene-3-methyl adipate (fig. 33) again indicates that methyl substitution in either the diol or the diacid does not contribute substantially to the cross-linking reaction in the positions evaluated in this study. Poly-2,2-dimethyltrimethylene-3,3-dimethyl glutarate also failed to cross-link readily (fig. 34) in contrast to the poly-2,2-dimethyltrimethylene adipate and azelate (figs. 21 and 22) which crosslink. Again, methyl substitution in the diol does not aid the cross-linking reaction, whereas methyl substitution on the alpha or beta carbon atom in the dicarboxylic acid retards cross-linking.

\section{RADIATION SOURCE AND DOSE RATE EFFECT ON}

\section{SATURATMED ITIEAR POLYESTEERS}

Ionization density has been shown to be important in some radiation-induced reactions and unimportant in others (refs. 40 and 41). A square-root dependence on the radiation intensity has been shown for free-radical polymerizations induced by radiation ( ref. 41); however, it has been predicted that the crosslinking of polymers would be independent of radiation intensity (ref. 42), and 
this has been found to be true up to a rate of about 1 megarep per second (p. 262 of ref. 43). In these studies, the polymer polytetramethylene sebacate was selected for study, and the intrinsic viscosity of the irradiated polymers was found to coincide within experimental limits with dose rates from 1 megarep per hour (about 0.0167 megarep per minute) to 1400 megareps per minute during actual pulses of irradiation (fig. 36). A similar effect has been shown for polyethylene (ref. 44) by determining the amount of insolubles produced on irradiation with a linear accelerator with dose rates within the range of 6 to 2070 megarads per minute, absorbed during actual pulses of irradiation. In the present studies, the effect was also found to be independent of three radiation sources, namely, a cobalt 60 source, a Van de Graaff accelerator, and a linear electron accelerator.

\section{INFLUENCE OF AIR AND FILM THICKNESS ON EFFECT OF}

\section{IONIZING RADIATION ON INTRINSIC VISCOSITY OF}

POLYTETRAMETHYLENE SEBACATE

The effect of the presence of an oxygen atmosphere on a polymer during its exposure to ionizing radiation tends to cause decomposition in some polymers, whereas in others there appears to be little or no observable effect, and in still others, the effect is still a matter of disagreement. Polyethylene, which cross-links readily in the absence of oxygen, reacts with oxygen during irradiation (ref. 45); thus, greater dosages are required for gelation (ref. 46), and the polymer actually undergoes degradation in the presence of oxygen (ref. 47). Polystyrene, which cross-links at high irradiation dosages in the absence of oxygen, does not gel in its presence, no matter how high the radiation dose (refs. 46 and 48 ).

Polyisobutylene does not cross-link at all on irradiation, and the extent of scission is claimed to be about the same whether the irradiation is performed in air, nitrogen, or vacuum (ref. 49), although the presence of oxygen changes the nature of the scission products. The presence of oxygen has been claimed to have no influence on the scission of polymethyl methacrylate (ref. 50), and in another case, the scission was claimed to be retarded (ref. 51). Since neither polyisobutylene nor polymethyl methacrylate is considered as being cross-linked by irradiation, whether oxygen is present or not, no generalized conclusion can be drawn from their behavior under irradiation. There is no information on the influence of oxygen during irradiation on the saturated linear polyesters of this study and only meager information on polyethylene terphthalate, which suffers a decrease in intrinsic viscosity in the absence as well as in the presence of air (refs. 14 to 16).

For oxygen to have a marked effect on the intrinsic viscosity of the polymer, it must, of course, diffuse into the polymer at a rate comparable with the rate of reaction within the polymer. If oxygen diffusion is slow compared with radical formation, all of the oxygen initially dissolved in the surface of the polymer will be rapidly consumed, and thereafter, the reaction within the polymer will proceed normally as in the absence of oxygen. Thus, it has been shown 
that with thick blocks of polymers, the oxygen effects are confined to the surface, whereas with the films, the effects are observed through the polymer (refs. 45, 46, and 52).

Both the oxygen-diffusion effect and the thickness effect were observed when polytetramethylene sebacate was irradiated in the presence of oxygen. As the oxygen pressure was increased, more degradation was observed, and as the film thickness was increased, degradation was found to decrease (table 40 and fig. 37). These observations confirm the work of Charlesby (ref. 45) and Dole and his co-workers (ref. 52).

\title{
INFLUENCE OF CRYSTALLINITY AND ORIENTATION
}

\author{
ON INTRINSIC VISCOSITY OF IRRADIATED
}

\section{POLYTETRAMETHYLENE SEBACATE}

The orlented polytetramethylene sebacate polymer was found to cross-link less readily than the unoriented polymer which, in turn, cross-linked less readily than the amorphous polymer (table 41 and fig. 38). This behavior indicates that cross-linking occurs primarily in the amorphous rather than in the crystalline regions in the polymer, as would be expected if chain motion is restricted in the crystalline regions of the polymer. In this respect, the behavior of these polymers is similar to the behavior of crystalline and amorphous polyethylene under ionizing radiation (ref. 53). In studies of nuclear magnetic resonance, this has been shown to be the case for polyethylene in which greater resistance to chain motion was indicated in the crystalline regions than in the amorphous regions (ref. 54).

For polyethylene, it has also been shown in reference 53 that radicals are trapped in the crystalline regions of the polymer and that the more highly crystalline the polymer, the larger the number of trapped radicals. The radicals formed in the crystalline region are not free to move to form intermolecular cross-links because of the restraining forces within the crystal; thus, they remain as radicals until they are made to react by one or more of several mechanisms. One method is to react them with oxygen. Another method involves the heating of the polymer which causes the development of more cross-links as a delayed reaction. Delayed cross-linking was shown to give less cross-links for the same irradiation dose than when the polymer was irradiated in the amorphous state. This decrease is due to the fact that not as many radicals are formed in polymers of high crystallinity, as indicated by evolution of greater quantities of hydrogen when the polymer is irradiated in the amorphous state.

The heating of oriented and unoriented polytetramethylene sebacate polymers, irradiated at their melting points with dosages below gelation, caused an increase in intrinsic viscosity of both polymers. The oriented filament, which is more dense and crystalline than the unoriented filament, had an increase in intrinsic viscosity of 0.026 (from 0.420 to 0.446 ); whereas, the unoriented filament had an increase of only 0.014 (from 0.440 to 0.454 ). This difference indicates a larger concentration of trapped radicals in the oriented filament 
than in the unorlented polymer. The final value of the intrinsic viscosity of the oriented fllament (after heating) was still less than that of the unoriented filament. The viscosities for both filaments were much less than that for an amorphous polymer. The viscosities of the crystalline polymers never equaled the intrinsic viscosity of the amorphous polymer when irradiated to the same dose. The behavior of these polyesters parallels, therefore, that reported for crystalline and noncrystalline polyethylenes (ref. 53).

When irradiated polyesters are stored in air, a new infrared absorption band appears at $6.42 \mu$, which is assigned to a -C-C- structure. The appearance of this band indicates the formation of a new carbonyl similar to the formation of carbonyl in polyethylene, which is detected (ref. 53) by infrared absorption in the $5.84 \mu$ region.

\section{CEANGES IN COMPOSITION OF SOME POLYESTERS ON IRRADIATION}

When thin films are irradiated, the weight loss of the film due to the loss of the products of the scission reaction is higher than the loss with thicker f1lms (table 43); thus, a diffusion effect is indicated. In thin films, the gaseous scission products can diffuse away; whereas, in thicker films, such fragments may recombine with polymer fragments or with each other and be retained before diffusion can occur. This behavior is indicated by a weight loss of 4.92 percent for films of 0.25 -millimeter thickness as compared with a weight loss of 1.84 percent for films of 0.75 -millimeter thickness, after postevacuation to constant weight. Accordingly, films of 0.25 -millimeter thickness were used in studies of the radiation-induced change of the elemental composition of polymers (table 44) and for the determination of the composition of the gases eliminated from the polymer as a result of scissions during the irradiation (table 45).

The carbon, hydrogen, and oxygen values for polytetramethylene sebacate were not found to change greatly when irradiated in vacuo, even to large irradiation dosages of 400 megareps. However, when the polymer is irradiated in air, its oxygen content is greatly increased; thus, the percentage of carbon and hydrogen decreases with accompanying changes in the infrared absorption spectra. On the other hand, polyethylene succinate exhibits greater changes in the carbon, hydrogen, and oxygen ratios as a result of a greater number of scissions in $1 t$ than the polytetramethylene sebacate. These changes are also reflected in the gaseous products eliminated from these polymers by irradiation (table 45). In all the polymers irradiated, the major gaseous product was hydrogen. Qualitatively, this is in agreement with the results from the irradiation of polyethylene, in which case the hydrogen yleld has been reported in the range of 96 to 98 mole percent (ref. 55). The yield of hydrogen in polytetramethylene sebacate is less than half of that from polyethylene as a result of the contribution by scissions in the ester links of 16.5 mole percent of CO and 9.7 mole percent of $\mathrm{CO}_{2}$ as well as by other byproducts. The yield value of 44 mole percent of $H$ is in good agreement with the value of 44.1 reported by Shultz (ref. 26) for polymethyl methacrylate, which had received a dosage of 
92 megareps. Gaseous yields for irradiated polymethyl methacrylate were also reported (ref. 26) for $\mathrm{CO}$ as 22.8 mole percent and for $\mathrm{CO}_{2}$ as 18.8 mole percent; these values are generally of the same order of magnitude as those found for polyethylene succinate. The high $\mathrm{CO}$ and $\mathrm{CO}_{2}$ values for polymethyl methacrylate would indicate that the rupture of the pendant ester chains occurs more frequently than the rupture of the main chain; thereby, the intrinsic viscosity of the polymer is largely unchanged. In polyethylene succinate, the ester links are in the primary chain and scissions resulting from irradiation, in the absence of a viscosity or crystallinity cage, would cause a greater loss; this is reflected in the 29.8-mole-percent loss of products other than $\mathrm{H}_{2}, \mathrm{CO}$, and $\mathrm{CO}_{2}$ as compared with a total of 7 mole percent for polymethyl methacrylate.

In contrast to polyethylene succinate, the composition of gaseous products from polytetramethylene sebacate changes remarkably; the quantity of hydrogen is increased to 49.6 mole percent, and the amount of hydrocarbons and other byproducts is reduced to approximately 6 to 7 mole percent; this reflects to some degree the activity of a crystallinity cage effect. The increase in hydrogen may also be due to the higher concentration of hydrogen existing in the form of more $-\mathrm{CH}_{2}$ - groups per unit volume of polymer. Polydecamethylene sebacate, which also is a highly crystalline polymer and has a higher initial concentration of $-\mathrm{CH}_{2}-$ groups per unit volume of polymer, showed not only the viscosity and crystallinity cage effects but also liberated a higher amount of hydrogen (61.9 mole percent), about the same amount of $\mathrm{RH}$ and other byproducts, and $\mathrm{a}$ lower total amount of $\mathrm{CO}$ and $\mathrm{CO}_{2}$ (28.4 mole percent) than polytetramethylene sebacate ( 44 mole percent of $\mathrm{CO}$ plus $\mathrm{CO}_{2}$ ). It will also be noted that as the length of the methylene bridges in the polyester increases, not only does the amount of hydrogen formed during irradiation increase, but the mole ratio of $\mathrm{CO}$ to $\mathrm{CO}_{2}$ decreases from about 2:1 to 1:1. In this regard polydecamethylene sebacate is very similar to the nonpolymeric cetyl palmitate (refs. 27 and 28), wherein the mole ratio of $\mathrm{CO}$ to $\mathrm{CO}_{2}$ is about 1 and the amount of hydrogen liberated is 85 mole percent. However, one may speculate that if more $-\mathrm{CH}_{2}-$ groups are inserted in the decarboxylic acid bridge of polydecamethylene sebacate, the value of the hydrogen liberated will increase from 62 percent to values approaching those found in cetyl palmitate and similar compounds.

The irradiation of low-molecular-weight carboxylic acids caused decarboxylation of the acid among other effects, and the major gaseous product is $\mathrm{CO}_{2}$ as illustrated by caprylic acid (refs. 27 and 28 ), which has a mole ratio of co to $\mathrm{CO}_{2}$ of about $1: 6$. In sebacic acid, this ratio is even more unfavorable, being of the order of 1:35. It is worthy to note that polyesterification with 1,4-tetramethylene diol reverses this ratio to about $1.5: 1$ and that when 1,10 -decamethylene glycol is used the ratio becomes approximately $1: 1$. These results indicate that the major scission reaction in the acid can occur by rupture of the oxygen-hydrogen bond, $-\mathrm{CH}_{2} \mathrm{C}-\mathrm{O} \frac{3}{\xi}-\mathrm{H}$; whereafter, the hydrogen radical diffuses from the environment and leaves the $-\mathrm{CH}_{2} \mathrm{C}-0$. radical to disproportionate 
and to liberate $\mathrm{CO}_{2}$. In the case of the polyesters, the radical fragments, $-\mathrm{CH}_{2} \stackrel{\mathrm{C}}{\mathrm{C}}-\mathrm{O}-\frac{3}{\xi}-\mathrm{CH}_{2}-$, are restrained by a cage effect, and before decarboxylation is completed, recombination occurs and the formation of $\mathrm{CO}_{2}$ is reduced.

The presence of $\mathrm{CO}$ may be attributed to (1) a reduction of $\mathrm{CO}_{2}$ by hydrogen radicals which would be higher in the polymer than in the nonpolymer because of the possible retention of $\mathrm{CO}_{2}$ and $\mathrm{H}$ in the viscous polymer, or (2) a scission

occurring at the carbon-oxygen bond in the acid, $-\mathrm{CH}_{2} \mathrm{C}-\mathrm{i}$ ination of $\mathrm{CO}$ from the $-\mathrm{CH}_{2} \mathrm{C}$. radical. It would be extremely fortuitous in those cases where $\mathrm{CO}_{2}$ is liberated if exactly one-half of it is reduced to $\mathrm{CO}$; and for that reason, it is speculated that the presence of equal molar amounts of $\mathrm{CO}$ and $\mathrm{CO}_{2}$ is due to an equal probability of rupture of the carbon-oxygen bonds on either side of the oxygen atom derived from the alcohol, thus<smiles>CCC(=O)C(C)(C)OCCCCCCC(=O)OC(C)(C)CC</smiles>

GRAFTING OF MONOMERS TO SATURATED LINEAR POLYESTERS

The presence of divinylbenzene admixed with polytetramethylene sebacate or polyethylene sebacate greatly influences the changes in intrinsic viscosity of the resulting grafted polymer even at radiation dosages below the gel point (table 46 and fig. 40). This effect indicates a relatively large increase in the cross-linking reaction. When large amounts of divinylbenzene were used, such as 9.09 percent (commercial divinylbenzene also contains almost an equal amount of ethyl vinylbenzene), the intrinsic viscosity first decreased before it increased eventually to the gel point. This behavior is in accord with the Inokuti effect ( ref. 33) because of the broad molecular distribution resulting from the presence of the polymer and large amounts of monomeric ethyl vinylbenzene and divinylbenzene which have lower average molecular weights than the polymer.

In order to confirm that polyfunctional monomers such as divinylbenzene aid cross-linking and thereby reduce the irradiation dosage required to produce gel, the studies were extended to include doses above the gelation dose. The amount of gel formed and the swelling potential of the polymers were determined as a function of both the irradiation dose and the divinylbenzene concentration. The amount of cross-linked polymers formed is proportional to the amount of divinylbenzene present, and the gel increases with irradiation dosages for compositions from 0- to 3.74-percent divinylbenzene (table 47 and fig. 41). With higher amounts of divinylbenzene, such as 9.09 and 33.3 percent, the amount of gel increases very rapidly with irradiation dosages to a point where a reversal occurs and the amount of gel decreases, which indicates that scissions are 
occurring. Since such a phenomenon was not observed in compositions with lower amounts of divinylbenzene, it was suspected that the larger amounts of ethyl vinylbenzene present in the mixtures containing 9- and 33-percent divinylbenzene copolymerized in the graft and during increased irradiation underwent decomposition. There are no published data on alkylated polystyrenes which either justify this conclusion or provide a basis for a comparison. The analysis of Schultz (ref. 56) has shown that if the ratio of scission to cross-linking $(\beta / \alpha)$ is 0.35 , then the ratio of the intrinsic viscosity for the irradiated polymer to that for the unirradiated polymer should initially increase and then decrease rapidly. This latter reaction occurs when the ratio $R / R^{*}$ (where $R$ is a dose below the gelation dose and $R^{*}$ is the critical dose for gelation) reaches the range of 0.6 to 0.8 , which is interpreted as meaning that scissions have occurred and branched polymers have been produced. On the supposition that scission in these polymers was due to ethyl styrene segments, pure p-divinylbenzene (free of ethyl styrene) was used at a concentration of 9 percent with polytetramethylene sebacate at dosages beyond the point where reversal was encountered with the mixture of divinylbenzene and ethyl vinylbenzene. Under these conditions, the reversal was not encountered up to a dose of 25 megareps.

In order to further confirm that the tetrafunctional divinylbenzene monomer is responsible for the increase of the radiation efficiency in crosslinking, a comparison of the cross-linking efficiency of divinylbenzene with that of the difunctional monomer, styrene was made (table 48 and fig. 42). The contrast is remarkable; styrene contributes nothing to the cross-Iinking efficiency, and in fact, the amount of gel formed is always less, at comparable radiation dosages, when styrene is present with the polyester. Apparently, most of the styrene appears as grafted branches on a network of cross-linked polyesters, whereas most of the divinylbenzene actually forms bridges between the polyester chains. Accordingly, there is a fundamental difference in the behavior of vinyl monomers of functionality of two and those of functionality greater than two in grafting reaction under the influence of irradiation. The grafting of monovinyl monomers with a functionality of two may be properly termed "branch grafting" and that of polyvinyl monomers with a functionality of four or more, termed "bridge grafting." When mixtures of divinylbenzene and polytetramethylene sebacate are irradiated, the divinylbenzene affects the swelling index (table 50 and fig. 44) as would be expected from the amount of gel found in the irradiated polymers (table 46 and fig. 40); that is, the swelling index decreases with increases in the amount of divinylbenzene and the irradiation dose. However, the low values of approximately 2 and 1 for the swelling index at 9.09- and 33.3-percent divinylbenzene, respectively, fail to reflect the large amount of extractable, soluble uncross-Iinked polymer formed in these bridge-grafted polymers when the radiation dose is increased and an inversion occurs (fig. 4I). This same falling is found when measurements of the swelling index of irradiated mixtures of divinylbenzene and polyethylene succinate are compared with the amount of soluble polymer. In these cases, where polymer degradation is encountered simultaneously with the formation of tight, highly cross-linked structures, the swelling index is of limited value and must be evaluated simultaneously with the determination of the amount of gel formed at the same irradiation dose.

As previously discussed, polyethylene succinate did not cross-link at doses up to 200 megareps. The dosage was extended to 400 megareps and still gelation 
was not observed. If multivinyl monomers are in reality bridge grafting monomers, some evidence to this effect should be found on irradiation of mixtures of such monomers and polymers which, under identical irradiation doses, do not cross-link. Polyethylene succinate with an intrinsic viscosity of 0.2 is Ideally suited for such a test.

This speculation was confirmed, and the amount of gel formed was proportional to the amount of divinylbenzene in the range of 1.96 - to 9.09-percent divinylbenzene (table 49 and $\mathrm{fig} .43$ ). In the absence of divinylbenzene, no gel was formed even up to a dose of 400 megareps, and the irradiated polymer remained completely soluble in chloroform. With 1.96-percent divinylbenzene, gel formation occurs only after a dose of 100 megareps, and as the amount of divinylbenzene is increased from 1.96 to 9.09 percent, gel formation occurs at decreasingly lower dosages. An examination of table 49 shows again that there is no precise relationship between the swelling index (column 4) of the crosslinked polymers and the amount of gel (column 3) in the polymer.

The improvement in irradiation cross-linking efficiency by the use of divinylbenzene with the saturated polyesters of this study is not specific to divinylbenzene but to many multifunctional monomers such as allyl acrylate, allyl methacrylate, methallyl methacrylate, ethylene glycol diacrylate, ethylene glycol dimethacrylate, diallyl benzene, divinyl phthalate, and many others (refs. 57 to 59). Nor is the irradiation cross-linking efficiency which results from the use of multifunctional monomers specific only to the type of polyester polymers used in this study. The fact that the irradiation dose at which polytetramethylene succinate (which cross-links readily alone) cross-links can be greatly reduced and that polyethylene succinate (which does not cross-link) can be cross-linked by the use of multifunctional vinyl monomers would indicate that this system might be useful with other polymers. This system should be useful in reducing the dose level of irradiation required to produce the desired degree of cross-linking in those polymers which (1) cross-link readily by radiation alone, (2) cross-link with radiation alone, but because of substantial degradation cross-link with difficulty, and (3) do not cross-link with irradiation or are degraded by irradiation. Polyethylene, polypropylene, and polyisobutylene exemplify these categories, and in all cases the predicted results were obtained (refs. 60 and 6I). Many other polymers, including polystyrene, the polyalkyl acrylates, the polyvinyl esters (refs. 60 and 61 ), polyvinyl chloride (ref. 62), polydimethyl silicone, and polyethylene terephthalate, are benefited by the presence in the polymer of multifunctional vinyl monomers during irradiation.

An extreme verification of the principle of bridge grafting is its application to substances such as the paraffin waxes, which are usually considered as nonpolymeric. A paraffin wax with a melting point of $60^{\circ} \mathrm{C}$ is continuously degraded when subjected to irradiation in the absence of air, and no evidence of cross-linking is obtained up to extreme doses of 2000 megareps; 3 yet, an infusible, cross-linked bridge-grafted paraffin is obtained when a mixture of 5 parts of divinylbenzene and 95 parts of wax is subjected to a 50 -megarep irradiation dose. A number of natural waxes have also been cross-linked in this manner. Many other types of multifunctional vinyl monomers were also used in irradiation bridge grafting to produce the same results.

3Private communication. J. Olander, High Voltage Engineering, Burlington, Massachusetts.

24 
Before irradiation, the main adsorption bands in the infrared are found in the regions of $2924,2865,1730,1473,1456,1406,1364,1348,1294,1221,1176$, 1079, 1068, 1053, 965, 857, 672, 730, and $720 \mathrm{~cm}-1$. The changes in the bands in the polymers irradiated in vacuo were, in general, too small at low or medium irradiation dosages to interpret accurately, but the changes, when the irradiation was performed in air, were very marked.

Minor changes were observed after irradiation in vacuo and in air in the regions of $1730,1176,1079$, and $1068 \mathrm{~cm}^{-1}$, which are characteristic of the ester groups, -C-O-C-, with increasing radiation dose. It was observed that the intensity of an ester band at $1068 \mathrm{~cm}-1$ does not change much with irradiation up to 150 megareps but that it does increase at higher doses of the order of magnitude of 400 megareps or higher. This low observable change can be explained by the fact that the total decrease in the number of ester groups due to scissions which cause the liberation of $\mathrm{CO}_{2}$ or $\mathrm{CO}$ is small (tables 44

and 45), and after irradiation in vacuo, the polymer shows an elemental analysis close to that of the original unirradiated polymer. In order to explain the loss of $\mathrm{CO}_{2}$ and $\mathrm{CO}$, the scission can be depicted as occurring in the ester group in the following two ways:

$$
\begin{aligned}
& -\mathrm{CH}_{2} \mathrm{COOCH}_{2}-\rightarrow-\mathrm{CH}_{2} \mathrm{COO} \cdot+\cdot \mathrm{CH}_{2}-\rightarrow \uparrow_{\mathrm{CO}_{2}}+-\mathrm{CH}_{2} \cdot+\mathrm{CH}_{2}- \\
& -\mathrm{CH}_{2} \mathrm{COOCH}_{2}-\rightarrow-\mathrm{CH}_{2} \mathrm{CO} \cdot+\cdot \mathrm{OCH}_{2} \rightarrow \mathrm{CO}+-\mathrm{CH}_{2}+\cdot \mathrm{OCH}_{2}-
\end{aligned}
$$

Recombination of the radicals in equation (2) produces an ether Iinkage, $-\mathrm{CH}_{2} \mathrm{OCH}_{2}-$, which absorbs in the same infrared region. The small total change in the insensity of the $1068 \mathrm{~cm}^{-1}$ band is due to the scission (eq. (1)), wherein the radical fragments recombine to give a hydrocarbon structure $-\mathrm{CH}_{2} \mathrm{CH}_{2}$ -

Further irradiation eventually destroys part of the ether linkage, which appears as a further slight decrease in the $1068 \mathrm{~cm}^{-1}$ ester band.

The crystallinity of polytetramethylene sebacate decreases with increased irradiation dosages, as indicated by a decrease in the crystallinity bands at $965 \mathrm{~cm}^{-1}, 957 \mathrm{~cm}^{-1}, 672 \mathrm{~cm}^{-1}$, and $730 \mathrm{~cm}^{-1}$. The crystalintinty band at $730 \mathrm{~cm}^{-1}$ decreases more rapidly than the other crystallinity bands.

The intensity of the band at $1406 \mathrm{~cm}^{-1}$, interpreted as due to the methylene group adjacent to the carbonyl group in the acid segment, $-\mathrm{CH}_{2} \mathrm{C}-\mathrm{O}-$, decreases much faster than that of any other band, till about 90 percent of the total 
hydrogen is liberated; whereas, the bands due to the other $-\mathrm{CH}_{2}$ - groups decrease at a much slower rate. This reaction is a function of irradiation dose both in vacuo and in air, which indicates that the cross-linking reaction occurs primarily through the alpha carbon atom of the dicarboxylic acid, and that the beta carbon atom plays a minor role. When the polymer is irradiated in vacuo, no new bands appear in the region of 730 to $1000 \mathrm{~cm}^{-1}$ where any formation of $-\mathrm{CH}=\mathrm{CH}-$ bonds would be expected to show absorption bands. However, when the polymer is irradiated in air, two new bands are formed, one at $1632 \mathrm{~cm}^{-1}$ which is assignable to the unsaturated structure, $-\mathrm{C}=\mathrm{C}-\mathrm{C}-$, and another at $1558 \mathrm{~cm}^{-1}$, assignable to the structure, $-\mathrm{C}-\mathrm{C}-\mathrm{O}-$. These two bands indicate that the alpha carbon atom is most probably the reactive site in the cross-linking reaction and that the beta carbon atom also plays an important but minor role. This observation could explain, in part, the previous finding that methyl group substitution on the alpha or beta carbon atom of the dicarboxylic acid retards the crosslinking reaction. A further confirmation of the location of these reactive sites is obtained by the appearance of the $1632 \mathrm{~cm}^{-1}$ band when polytetramethylene sebacate, irradiated in vacuo, is allowed to react with air as previously mentioned.

\section{DIAGNOSTIC SAPONIFICATION}

The data obtained in the diagnostic saponification of irradiated polytetramethylene sebacate supply some confirmatory evidence that the cross-linking occurs in the dicarboxyl acid component of the segmer. The data obtained by the diagnostic saponification are not completely conclusive; however, since the recovery of the original reactants was not 100 percent, the small amount of unaccounted diol and diacid could be responsible for a great portion of the cross-linked bonds.

This saponification procedure is difficult to execute to obtain quantitative recovery, and at the present time, it has been developed to attain a recovery of the starting reagents of about 99 percent in the uncross-linked polymer and of about 98 percent in the irradiated cross-linked polymers as compared with about 93 percent when the technique was first tried.

In a comparative study, the cross-linking activity of radicals generated on the alpha carbon atoms in dicarboxylic acid was demonstrated by irradiating polyethylene succinate which had been modified with maleic acid and had an intrinsic viscosity of 0.25 . This polyester was prepared by reacting 0.9 mole of succinic acid, 0.1 mole of maleic anhydride, and 1.05 mole of ethylene glycol and by subjecting it to irradiation. Whereas the unmodified polyethylene succinate degraded with increased irradiation dosages (fig. 1), the maleic-modified polyester gelled at a radiation dose of about 10 megareps. Simllarly, when 0.05 mole of sebacic acid was replaced by 0.05 mole of maleic anhydride in polytetramethylene sebacate, the amount of gel at a megarep dose increased from about 15 to 21 percent. 
A number of conclusions may be drawn from the data obtained in these studies on the irradiation of selected saturated straight-chain and branched polyesters. The results show that the structural features of the polyester segment, derived from polyesterification of specific diols and specific diacids, influence greatly the direction and magnitude of the radiation effects.

For the saturated linear polyesters, the diol exerts a strong influence on the direction of the reaction, that is, whether the scission reaction or the cross-linking reaction predominates. In the polyesters of succinic acid, the scission reaction is very evident when the segment is derived from diols having less than three $-\mathrm{CH}_{2}-$ groups and thus becomes less as the number of methylene groups is increased in the higher diols. When the number of methylene groups in the diol is greater than three, an increase in the number of methylene groups in the diacid does not exert a major influence on the cross-linking reaction, but in highly scissionable esters, such as the polyethylene esters, an Increase in the number of $-\mathrm{CH}_{2}-$ groups in the diacid is required to produce gels. Generally, cross-linking is favored by an increase in the number of methylene groups in the diol through stabilization of the ester link; thus, the ester scissions decrease. An increase in the number of methylene groups in both the diol and the acid favors crystallinity in the polymers; this results in a "crystallinity cage," that prevents the migration to some estent of scission fragments and produces a favorable increase in the $\alpha / \beta$ ratio. An increase in the number of methylene groups in either the diol or the diacid, or in both, results in a greater number of methylene groups per unit volume of segmer which decreases the probability of an interreaction of the radiation with the scissionable ester link; this reduces the number of probable scissions.

In all cases where the $\mathrm{CH}_{2} / \mathrm{COO}$ ratio exceeds $2 / 1$, cross-linking is obtained if the intrinsic viscosity, that is, the molecular weight, exceeds a minimum value which is in accord with the Franck-Rabinowitch cage effect. (This behavior is shown as a generalized composite in fig. 45.)

A generalization of the effect of branches in the polyesters of this study cannot be made, since it depends on the location of the branches in the segment, that is, whether they are located in the diol, in the diacid, or in both.

Propylene glycol (1-methylethylene diol) is the simplest branched diol avallable, and all of its polyesters of unbranched linear dicarboxylic acids were found to cross-link with radiation and to exhibit a vicsocity cage effect. Cross-linking was evident also in the succinate ester, but this behavior is in marked distinction to that of the corresponding ethylene ester, which does not cross-link. This difference is attributed to a stabilization of the ester linkages by the formation of a hyperconjugated ring structure rather than solely to an increase in the number of carbon atoms; this is apparent when one considers the behavior of polytrimethylene succinate or considers the formation of radicals on the branches of such polyesters as 2,2-dimethyltrimethylene glycol, 2,2-diethyltrimethylene glycol, and 3-methylpentamethylene glycol. Furthermore, increasing the length of the branch from a methyl group to an ethyl group in 
the diol did not favor the cross-linking reaction, as would be expected if radical formation occurred readily on the branches.

The introduction of branches on the alpha carbon atoms of the diacid sharply retarded cross-linking, as shown by the contrast in the radiation behavior of polypentamethylene succinate with that of both polypentamethylene-2-methyl succinate and polypentamethylene-2,3-diphenyl succinate. In the case of the diphenyl succinate polyester, the energy-sink stabilization effect of aromatic rings was also evident.

Methyl branching on the beta carbon atom of the dicarboxylic acid also reduced the cross-linking reaction as indicated in the contrast of poly-3-methylpentamethylene adipate with poly-3-methylpentamethylene-3-methyl adipate and of poly-2,2-dimethyltrimethylene adipate with poly-2,2-dimethyltrimethylene-3,3dimethyl glutarate. In both cases, branches in the alcohol did not increase markedly the cross-linking reaction.

The unusual behavior of certain polyesters, which is reflected by a decrease in intrinsic viscosity at low irradiation doses followed by final gelation at higher doses, confirms the Saito-Inokuti effect, which applies to those cases where the polymer has a broad molecular welght distribution and the probability of cross-linking within the polymer segment is less than four times the probability of degradation. The radiation effects on the polyesters were shown to be independent of the nature of the radiation source and of the dose rates within large limits. The presence of oxygen was shown to exert a degrading effect during irradiation, and thus, cross-linking is retarded; this degrading effect is proportional to the oxygen concentration and inversely proportional to the thickness of the polymer, which influences the diffusion of the oxygen into the polymer before its degrading mechanism is effective.

It was concluded also that cross-linking occurs mostly in the amorphous or liquid areas of the polymers though radicals are generated in the crystalline areas, but to a lesser degree. These radicals remain trapped in the crystalline areas until released by heating which results in delayed cross-linking or destruction of the radical by reaction with oxygen.

The scission reaction was shown to be located in the ester linkages, and the stability of these linkages was found to be dependent on the nature of the diol. Further confirmation of the site of scission was obtained by an analysis of the gases obtained by irradiation. These gases contained high concentrations of $\mathrm{CO}_{2}$ and $\mathrm{CO}$, even when irradiated in vacuo.

These yields of $\mathrm{CO}_{2}$ and $\mathrm{CO}$ were compared with the corresponding yields from aliphatic monocarboxylic acids and dicarboxylic acids from which the major gaseous product of irradiation decomposition is $\mathrm{CO}_{2}$; thus, esterification confers some stabilization to the carboxy group. Polyesterification reverses the $\mathrm{CO} / \mathrm{CO}_{2}$ ratio formed during scission as a result of viscosity and crystallinity cage effects. 
1. Bovey, Frank A.: The Effects of Ionizing Radiation on Natural and Synthetic High Polymers. Interscience Publ., Inc., 1958.

2. D'Alelio, G. F., and Häberli, R.: Radiation Chemistry of Synthetic Polymers in the Solid State. Chimia, vol. 13, no. 10, Oct. 1959, pp. 309-314.

3. Charlesby, A.: Effect of High-Energy Radiation on Long-Chain Polymers. Nature (Letters to the Editors), vol. 171, no. 4343, Jan. 24, 1953, p. 167.

4. Wall, Leo A.: Factors Influencing the Behavior of Polymers Exposed to HighEnergy Radiation. Jour. Polymer Sci. (Letters to the Editors), vol. XVII, no. 83, May 1955, pp. 141-142.

5. Miller, A. A., Lawton, E. J., and Balwit, J. S.: Effect of Chemical Structure of Vinyl Polymers on Crosslinking and Degradation by Ionizing Radiation. Jour. Polymer Scl. (Letters to the Editors), vol. XIV, no. 77, Nov. 1954, pp. 503-504.

6. St. Pierre, L. E., and Dewhurst, H. A.: Oxygen Effects in the Radiation Chemistry of Polyethylene. Jour. Chem. Phys. (Ietters to the Editor), vol. 29, no. 1, July 1958, pp. 241-242.

7. Dole, Malcolm: The Effect of Radiation on Colloidal and High Polymeric Substances. Paper 7 of Rep. of Symposium IV: Chemistry and Physics of Radiation Disometry (U.S. Army Chem. Center, Edgewood, Md.), Sept. 18-20, 1950.

8. Alexander, P., and Charlesby, A.: Energy Transfer in Macromolecules Exposed to Ionizing Radiations. Nature, vol. 173, no. 4404, Mar. 27, 1954, pp. $578-579$.

9. Lawton, E. J., Bueche, A. M., and Balwit, J. S.: Irradiation of Polymers by High-Energy Electrons. Nature (Letters to the Editors), vol. 172, no. 4367, July 11, 1953, pp. 76-77.

10. Sisman, O., and Bopp, C. D.: Physical Properties of Irradiated Plastics. ORNI-928, U.S. Atomic Energy Comm., 1951.

11. Bopp, C. D., and Sisman, 0.: Radiation Stability of Plastics and Elastomers. ORNL-1373, U.S. Atomic Energy Corm., 1953. (Supplement to ORNI-928.)

12. Jackson, Wallace A., and Hale, Denver: Vulcantzation of Rubber With HighIntensity Gamma Radiation. Rubber Age, vol. 77, 1955, pp. 865-871.

13. Gehman, S. D., and Hobbs, L. M.: Changes in Elastomers Due to Radiation From Cobalt. Rubber World, vol. 130, 1954, pp. 643-646.

14. Todd, Audrey: Pile Irradiation of Polyethylene Terephthalate ('Terylene'). Nature (Letters to the Editors), vol. 174, no. 4430, Sept. 25, 1954, p. 613. 
By the introduction of branches on the alpha and beta positions of dicarboxylic acids, it was shown indirectly that the cross-linking reaction occurs by the coupling of radicals formed in these carbon atoms. This concept was confirmed by observing changes in the intensity of the band due to the methylene group adjacent to the carbonyl group in the structure, $-\mathrm{CH}_{2}-\mathrm{C}-\mathrm{O}$. . The intensity of this band at $1406 \mathrm{~cm}^{-1}$ decreased more rapidly than that of any other band until about 90 percent of the total amount of hydrogen was liberated; however, the intensity of the bands due to the other methylene groups decreased at a much slower rate. When the polymers were irradiated in air, or when the irradiated polymer was allowed to react with oxygen, one new band appeared at $1558 \mathrm{~cm}^{-1}$ by the reaction of oxygen with the $-\mathrm{CH}_{2} \mathrm{C}-\mathrm{O}$ - group to form the $-\mathrm{C}-\mathrm{C}-\mathrm{O}-$ group, and at a slower rate, a second band characteristic of a $-\mathrm{C}=\mathrm{C}-\mathrm{C}-$ group appeared in the $1632 \mathrm{~cm}^{-1}$ region. No other new bands characteristic of the vinylene group, $-\mathrm{CH}=\mathrm{CH}-$, were found to appear in the region of 730 to $1,000 \mathrm{~cm}^{-1}$ where they would be expected to appear. Further evidence indicating that the alpha carbon atoms in the dicarboxylic acid are the preferred sites for crosis-linking was obtained by saponification of the irradiated cross-linked polymer and isolation of small amounts of multicarboxylic acids.

Vinyl monomers were grafted by irradiation to the polyesters of this study, and a fundamental difference was found in the behavior of monovinyl compounds having a functionality of two and multivinyl compounds having a functionality of at least four. Monovinyl compounds are branch-grafted to the polymers without increasing the amount of cross-linking or lowering the energy requirements of the cross-linking reactions. In contrast, the multivinyl compounds efficiently complement radiation in the production of cross-links in the polyesters and further reduce the dosages required to produce a definite amount of gel. The cross-linking efficiency of the multivinyl compounds is sufficiently great that cross-linked polyethylene succinates can be prepared through their use. The term "bridge-grafting" is proposed for this effect and it is not specific to these polyesters alone. Irradiation-produced bridge-grafting has broad utility and has been applied to a large number of polymers to (1) reduce the irradiation dosage in those polymers that cross-link readily, (2) cross-link readily those polymers which cross-link with difficulty because of high scission degradation, and (3) cross-link polymers which do not cross-link at all under irradiation or which are highly degraded by irradiation. As an extreme case, irradiation bridge-grafting has been extended and shown to be applicable to nonpolymeric systems, such as low-melting paraffin waxes and natural waxes. was also shown that in some polymers, the swelling index is not an accurate measurement of cross-linking values, especially when scission can still occur in segments between the cross-links, and that the determination of the amount of gel is a more suitable method. Studies on the effect of ionfing radiation on other polymers as well as polymers related to the polyesters of this research are still in progress. 
15. Iittle, K.: Irradiation of Iinear High Polymers. Nature (Ietters to the Editors), vol. 170, no. 4338, Dec. 20, 1952, pp. 1075-1076.

16. Iittle, K.: Some Effects of Irradiation on Nylon and Polyethylene Terephthalate. Nature (Letters to the Editors), vol. 173, no. 4406, April 10, 1954 , p. 680 .

17. Charlesby, A., Wycherley, V., and Greenwood, T. T.: Radiation Reactions of Unsaturated Polyesters. Proc. Roy. Soc. (Iondon), ser. A, vol. 244, no. 1236, Feb. 25, 1958, pp. 54-71.

18. Shultz, Allan R., and Bovey, Frank A.: Electron Irradiation of Polyacrylates. Jour. Polymer Sc1., vol. XXII, no. 102, Dec. 1956, pp. 485-494.

19. Charlesby, A.: The Cross-Linking and Degradation of Paraffin Chains by High-Energy Radiation. Proc. Roy. Soc. (Iondon), ser. A, vol. 222, no. 1148, Feb. 23, 1954, pp. 60-74.

20. D'Alelio, G. F.: Molecular Engineering. Soc. Plastics Fngineers Jour., vol. 8, no. 3, Mar. 1952, pp. 25-27, 40.

21. Carothers, Wallace H., and Arvin, J. A.: Studies on Polymerization and Ring Formation. II. Poly-Esters. Jour. American Chem. Soc., vol. 51, no. 8, Aug. 1929, pp. 2560-2570.

22. Carothers, Wallace H.: Linear Condensation Polymers. Serial No. 548,701. U.S. Patent Office (Washington, D.C.), 2,071,250, Feb. 16, 1937.

23. Hochanadel, C. J., and Ghormley, J. A.: Calorimetric Calibration of GammaRay Actinometers. Jour. Chem. Phys., vol. 21, no. 5, May 1953, pp. 880-885.

24. Burton, Milton, Ghormley, J. A., and Hochanadel, C. J.: Design of an Inexpensive High-Intensity Gamma Source. Nucleonics, vol. 13, no. 10, Oct. 1955, pp. 74-77.

25. Huggins, Maurice L.: The Viscosity of Dilute Solutions of Long-Chain Molecules. IV. Dependence on Concentration. Jour. American Chem. Soc., vol. 64,1942 , pp. 2716-2718.

26. Schultz, Allan R.: High- Thergy Radiation Effects on Polyacrylates and Polymethacrylates. Jour. Polymer Sci., vol. XXXV, no. 129, Mar. 1959, pp. 369-379.

27. Breger, Irving A.: Transformation of Organic Substances by Alpha Particles and Deuterons. Jour. Phys. and Colloid Chem., vol. 52, 1948, pp. 551-563.

28. Sheppard, C. W., and Whitehead, W. L.: Formation of Hydrocarbons From Fatty Aclds by Particle Bombardment. Bull. Amerizan Assoc. Petr. Geologists, vol. 30,1946 , pp. 32-51. 
29. Saito, Osamu: On the Effect of High Energy Radiation to Polymers I. Cross-linking and Degradation. Jour. Phys. Soc. of Japan, vol. 13, no. 2, Feb. 1958, pp. 198-206.

30. Salto, Osamu: Effects of High Energy Radiation on Polymers - II. EndLinking and Gel Fraction. Jour. Phys. Soc. of Japan, vol. 13, no. 12, Dec. 1958, pp. 1451-1464.

31. Salto, Osamu: Effects of High Energy Radiation on Polymers - III. Viscosity. Jour. Phys. Soc. of Japan, vol. 13, no. 12, Dec. 1958, pp. 1465-1476.

32. Danno, Akibumi: Gel Formation of Aqueous Solution of Polyvinyl Alcohol Irradiated by Gamma Rays From Cobalt-60. Jour. Phys. Soc. of Japan, vol. 13, no. 7, July 1958, pp. 722-727.

33. Inokuti, Mitio: On the Viscosity of Irradiated Polymers I. Jour. Phys. Soc. of Japan, vol. 14, no. 1, Jan. 1959, pp. 79-85.

34. Inokut1, Mitio, and Katsura, Kanji: On the Viscosity of Irradiated Polymers, II. Jour. Phys. Soc. of Japan, vol. 14, no. 10, Oct. 1959. pp. 1379-1387.

35. Flory, Paul J.: Random Reorganization of Molecular-Weight Distribution in Iinear Condensation Polymers. Jour. American Chem. Soc., vol. 64, 1942, pp. 2205-2212.

36. Flory, Paul J.: Thermodynamies of Heterogeneous Polymers and Their Solutions. Jour. Chem. Phys., vol. 12, no. 11, Nov. 1944, pp. 425-438.

37. Franck, J., and Rabinowitch, E.: Free Radicals and the Photochemistry of Solutions. Trans. Faraday Soc., vol. 30, Jan. 1934, pp. 120-131.

38. Carothers, Wallace H., and Dorough, G. I.: Studies on Polymerization and Ring Formation. IV. Ethylene Succinates. Jour. American Chem. Soc., vol. 52, no. 2, Feb. 1930, pp. 711-721.

39. Carothers, Wallace H., and Hill, Julian W.: Studies of Polymerization and Ring Formation. XII. Iinear Superpolyesters. Jour. American Chem. Soc., vol. 54, no. 4, Apr. 1932, pp. 1559-1566.

40. Schuler, Robert H., and Allen, Augustine 0.: Radiation-Chemical Studies With Cyclotron Beams. Jour. American Chem. Soc., vol. 77, 1955, p. 507.

41. Ballantine, D. S., Colombo, P., Glines, A., and Manowitz, B.: Gamma-RayInitiated Polymerization of Styrene and Methyl Methacrylate. Chem. Fng. Prog. Symposium, ser. 11, 1954, pp. 267-270.

42. Bopp, C. D., and Sisman, 0.: How Radiation Changes Polymer Mechanical Properties. Nucleonics, vol. 13, no. 10, Oct. 1955, pp. 51-55. 
43. Charlesby, A.: Fffect of Radiation on Behavior and Properties of Polymers. The Effects of Radiation on Materials, J. J. Harwood, Henry H. Hausner, J. G. Morse, and W. G. Ranch, eds., Reinhold Pub. Corp. (New York), c.1958, pp. 261-286.

44. Atchison, G. J.: Dose Rate Effect on Crosslinking of Polyethylene With High Energy Electrons in Vacuo. Jour. Polymer Sci. (Letters to the Editors), vol. XXXV, no. 129, Mar. 1959, pp. 557-558.

45. Charlesby A.: Cross-Linking of Polythene by Pile Radiation. Proc. Roy. Soc. (London), ser. A, vol. 215, no. 1121, Nov. 25, 1952, pp. 187-214.

46. Alexander, P., and Toms, D.: The Effect of Oxygen on the Changes Produced by Ionizing Radiations in Polymers. Jour. Polymer Sci. (Letters to the Editors), vol. XXII, no. 101, Nov. 1956, pp. 343-348.

47. Chapiro, Adolphe: Action of X-Rays on Polymers in the Solid State - I. Reticulation of Polyethylene. Jour. Chimie Physique, t. 52, 1955, pp. 246-258.

48. Feng, Paul Yen-Hsiung, and Kennedy, Joseph W.: Electrical and Chemlcal Effects of B-Radiation in Polystyrene. Jour. American Chem. Soc., vol. $77,1955, \mathrm{pp} .847-851$.

49. Alexander, P., Black, R. M., and Charlesby, A.: Radiation Induced Changes in the Structure of Polyisobutylene. Proc. Roy. Soc. (Iondon), ser. A, vol. 232, no. 1188, Oct. 11, 1955, pp. 31-48.

50. Alexander, P., Charlesby, A., and Ross, M.: The Degradation of Solid Polymethylmethacrylate by Ionizing Radiation. Proc. Roy. Soc. (London), ser. A, vol. 223, no. 1154, May 6, 1954, pp. 392-404.

51. Wall, Leo A., and Brown, Daniel W.: Chemical Activity of Gamma-Irradiated Polymethyl Methacrylate. Res. Paper 2702, Jour. Res. Nat. Bur. Standards, vol. 57, no. 3, Sept. 1956, pp. 131-136.

52. Dole, Malcolm, Keeling, C. D., and Rose, D. G.: Pile Irradiation of Polyethylene. Jour. American Chem. Soc., vol. 76, 1954, pp. $4304-4311$.

53 Lawton, Elliott J., Balwit, J. S., and Powell, R. S.: Effect of Physical State During the Electron Irradiation of Hydrocarbon Polymers. Part I. The Influence of Physical State on Reactions Occurring in Polyethylene During and Following the Irradiation. Jour. Polymer Sc1., vol. XXXII, no. 125, Nov. 1958, pp. 257-275.

54. Slichter, W. P., and McCall, D. W.: Molecular Motion in Polyethylene. Bull. American Phys. Soc., ser. II, vol. 2, no. 3, Mar. 21, 1957, p. 125.

55. Dole, Malcolm, and Keeling, C. D.: Long-Range Migration of Chemical Activity in the Solid State. Jour. American Chem. Soc., vol. 75, 1953, pp. 6082-6083. 
56. Shultz, Allan R., Roth, Paul I., and Rathmann, George B.: Light Scattering and Viscosity Study of Electron-Irradiated Polystyrene and Polymethacrylates. Jour. Polymer Sc1., vol. XXII, no. 102, Dec. 1956, pp. 495-507.

57. D'Alelio, Gaetano F.: Irradiated Polymers. Serial No. 707,080. U.S. Patent Office (Washington, D.C.), 3,075,904, Jan. 29, 1963.

58. D'Alelio, Gaetano F.: Irradiated Polymers. Serial No. 707,082. U.S. Patent Office (Washington, D.C.), 3,074,866, Jan. 22, 1963.

59. D'Alelio, Gaetano F.: Irradiated Polymers. Serial No. 707,084. U.S. Patent Office (Washington, D.C.), 3,082,161, Mar. 19, 1963.

60. D'Alelio, Gaetano F.: Combustion Processes Employing Irradiated Sol1d Polymeric Fuels Containing Oxidizing Agents. Serial No. 763,485. U.S. Patent Office (Washington, D.C.), 3,003,310, Oct. 10, 1961.

61. D'Alelio, Gaetano F.: Combustion Process Using Irradiated Polymeric Fuel. Serial No. 763,486. U.S. Patent Office (Washington, D.C.), 3,071,923, Jan. 8, 1963.

62. Miller, A. A.: Radiation - Cross Linking of Plasticized Poly (Vinyl Chloride). Ind. and Eng. Chem., vol. 51, 1959, pp. 1271-1274. 


\begin{tabular}{|c|c|c|}
\hline $\begin{array}{l}\text { Resgents } \\
\text { (a) }\end{array}$ & & Source \\
\hline Succinic acid ...... & $\cdot \cdot$ & Eastman Organic Chemicals Co. \\
\hline Glutaric acid ...... & . • & Eastman Organic Chemicals Co. \\
\hline Adiplc acid . . . . . & . • & E. I. du Pont de Nemours \& Co. \\
\hline Sebacic actd...... & . . & Harchem. Div. of Wallace \& Tiernan, Inc. \\
\hline 3,3-dimethyl glutaric acid. & . • & Aldrich Chemical Co. \\
\hline 3-methyl adipic acid . . . & . • • & Aldrich Chemical Co. \\
\hline Azela1c acid . . . . . & . . & Aldrich Chemical Co. \\
\hline Methyl succinic acid ... & . . & (b) \\
\hline 2,3-diphenyl succinic acid & . . & (c) \\
\hline Ethylene glycol ..... & $\cdot \cdot \cdot$ & Fisher Scientific Co. \\
\hline Propanediol-1,3 ..... & . • & Eastman Organic Chemicals Co. \\
\hline Butanediol-1,4 . . . . & . • & $\begin{array}{l}\text { Antara Chemicals Div. of General Aniline } \\
\text { and Film Co. }\end{array}$ \\
\hline Pentanediol-1,5 . . . . & $\cdot \cdot$ & Carbide and Carbon Chemical Co. \\
\hline Propanediol-1,2 . . . . & . • & Dow Chemical Co. \\
\hline 2,3-dimethyl propanediol-1,3 & . . & Eastman Chemical Products, Inc. \\
\hline 2,2-diethyl propanediol-1,3 & • • & Carbide and Carbon Chemical Co. \\
\hline 3-methyl pentanediol-1,5.. & $\cdot \cdot$ & Carbide and Carbon Chemtcal Co. \\
\hline Chloroform . . . . . . & . $\cdot$ & Flsher reagent grade \\
\hline Nitrogend & . $\cdot$ & Cleveland Wire Div. of General Electric Co. \\
\hline Styrene $^{e} \cdot \ldots \cdot \ldots$ & $\cdot \cdot$ & Foster Grant Co. \\
\hline Divinylbenzene $^{f}$..... & . • & Dow Chemical Co. \\
\hline Dowex 50 and Dowex 2 resins & . •. & Dow Chemical Co. \\
\hline
\end{tabular}

$a_{A}$ ll commercial grade chemicals were purified before use either by fractional distillation or crystallization, and the purity of the compounds was verified by checking melting points or refractive indices.

Itaconic acid supplied by Chas. Pfizer \& Co. was hydrogenated with W-6 Raney Nickel at $25^{\circ} \mathrm{C}$.

$c_{2}$,3-diphenyl succinyl nitrile was hydrolyzed with $96 \% \mathrm{H}_{2} \mathrm{SO}_{4}$ supplied by R. B. Davis, C.S.C., Dept. Chemistry, Untr. Notre Dame.

d99.99+\% purity; oxygen content less than $5 \mathrm{ppm}$.

e99.83\% purity.

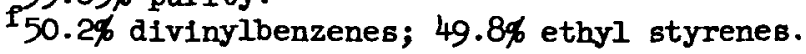


TABLE 2.- STRAIGHT-CHAIN POLYESTERS INVESTIGATED

\begin{tabular}{|c|c|c|c|c|}
\hline \multirow{2}{*}{\multicolumn{3}{|c|}{ Polymer }} & \multicolumn{2}{|c|}{ Carbon atoms in - } \\
\hline & & & Alcohol & Acid \\
\hline Polyethylene succinate $\cdot$. & $\cdot$ & - . & 2 & 4 \\
\hline Polyethylene adipate . . . . & - & - $\cdot$ & 2 & 6 \\
\hline Polyethylene azelate $\cdot \cdot \cdot \cdot$ & $\cdot$ & - $\cdot$ & 2 & 9 \\
\hline Polyethylene sebacate $\cdot$. . & • & · $\cdot$ & 2 & 10 \\
\hline Polytrimethylene succinate. & . & . & 3 & 4 \\
\hline Polytrimethylene adipate . . & - & - . & 3 & 6 \\
\hline Polytrimethylene sebacate . & . & - & 3 & 10 \\
\hline Polytetramethylene succinate & - & - & 4 & 4 \\
\hline Polytetramethylene adipate . & - & - . & 4 & 6 \\
\hline Polytetramethylene sebacate & - & - & 4 & 10 \\
\hline Polypentamethylene succinate & . & • & 5 & 4 \\
\hline Polypentamethylene adipate . & - & . & 5 & 6 \\
\hline Polypentamethylene azelate . & - & - & 5 & 9 \\
\hline Polypentamethylene sebacate & - & - & 5 & 10 \\
\hline Polydecamethylene sebacate . & - & . & 10 & 10 \\
\hline
\end{tabular}




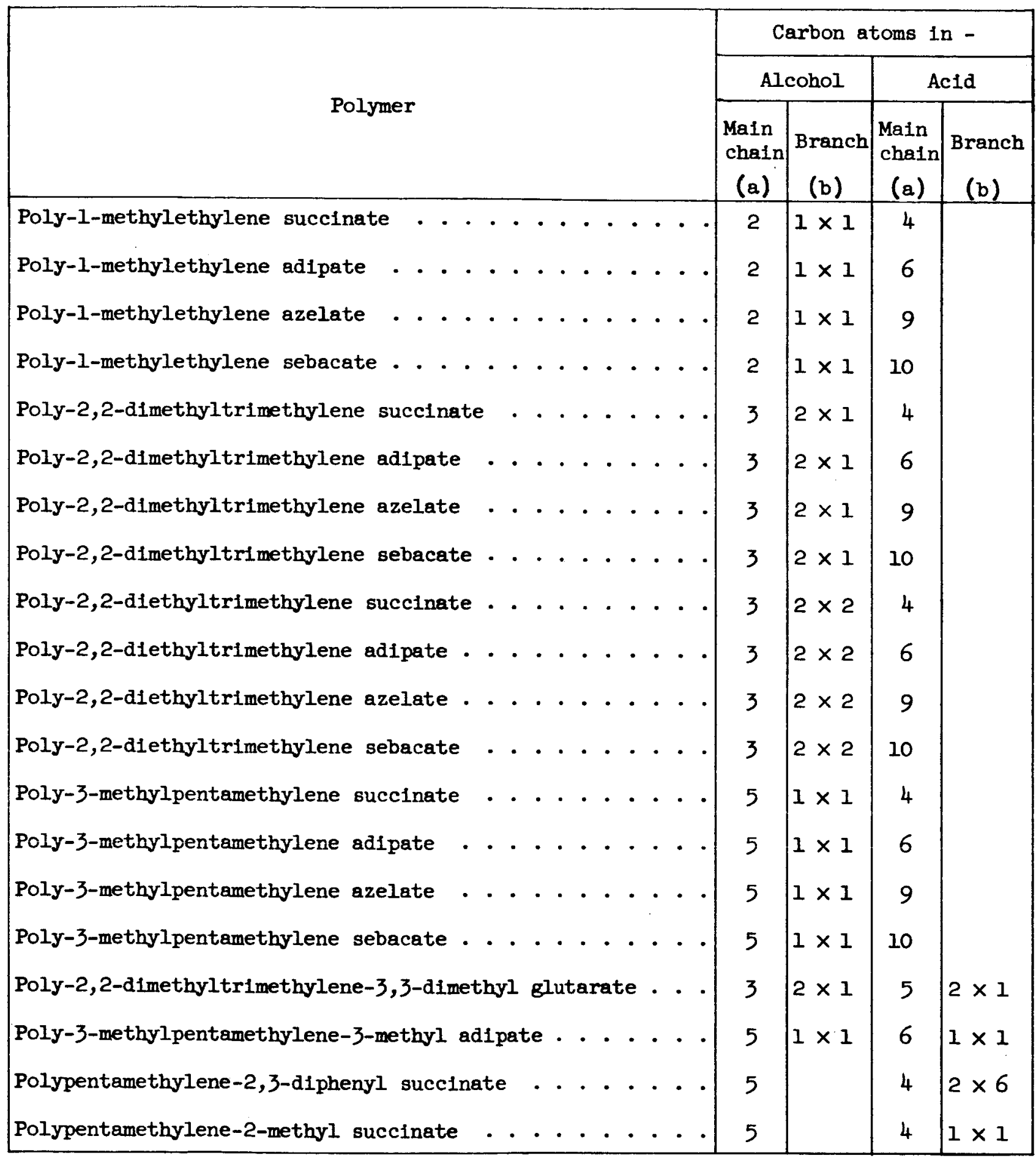

${ }^{a}$ Number of carbon atoms in main chain.

biumber of carbon atoms in branch; the expression $2 \times 1$ signifies that there are two branches each of which contains one carbon atom, and $2 \times 6$ signifies two branches each of which contains six carbon atoms. 
TABLE 4.- EFFECT OF IRRADIATION ON INTRINSIC

VISCOSITY OF POLYETHYTENE SUCCINATI

[See flgure 1]

\begin{tabular}{|c|c|c|c|c|}
\hline \multirow{2}{*}{$\begin{array}{l}\text { Dose, } \\
\text { megarep }\end{array}$} & \multicolumn{4}{|c|}{ Intrinsic viscosity, $[\eta]$} \\
\hline & A & B & C & $\mathrm{D}$ \\
\hline 0 & $\mathrm{a}_{0.060}$ & ${ }^{\mathrm{b}} 0.190$ & $c_{0.238}$ & $\mathrm{~d}_{0.312}$ \\
\hline 5 & .059 & .182 & .206 & .341 \\
\hline 10 & .059 & .160 & .172 & .324 \\
\hline 25 & .059 & .116 & .143 & .260 \\
\hline 50 & .059 & .101 & .112 & .232 \\
\hline 100 & .048 & .086 & .090 & .168 \\
\hline
\end{tabular}

Polycondensation was performed:

at $250^{\circ} \mathrm{C}$ for $6 \mathrm{hr}$ at 1 atm.

bat $235^{\circ} \mathrm{C}$ for $5 \mathrm{hr}$ at 1 atm, then for $5 \mathrm{hr}$ at $0.3 \mathrm{~mm}$.

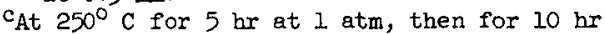
at $0.5 \mathrm{~mm}$.

$\mathrm{d}_{\text {At }} 250^{\circ} \mathrm{C}$ for $6 \mathrm{hr}$ at $1 \mathrm{~atm}$, then for $20 \mathrm{hr}$ at $0.5 \mathrm{~mm}$.

TABLE 6.- EFFECT OF IRRADIATION ON INIRINSIC VISCOSITY OF POLYETHYLENE AZELATE [See figure 3]

\begin{tabular}{|c|c|c|}
\hline \multirow{2}{*}{$\begin{array}{c}\text { Dose, } \\
\text { megarep }\end{array}$} & \multicolumn{2}{|c|}{ Intrinsic viscosity, [T] } \\
\cline { 2 - 3 } & $\mathrm{A}$ & $\mathrm{B}$ \\
\hline 0 & $\mathrm{a}_{0.068}$ & $\mathrm{~b}_{0.404}$ \\
5 & .054 & .418 \\
10 & .053 & .354 \\
25 & .039 & .336 \\
50 & .041 & $\mathrm{Gel}$ \\
100 & .040 & $\mathrm{Gel}$ \\
\hline
\end{tabular}

Polycondensation was performed:

at $250^{\circ} \mathrm{C}$ for $6 \mathrm{hr}$ at 1 atm.

bat $250^{\circ} \mathrm{C}$ for $6 \mathrm{hr}$ at $1 \mathrm{~atm}$, then for $10 \mathrm{hr}$ at $0.5 \mathrm{~mm}$.
TABLE 5.- EFF'ECT OF IRRADIATION ON INIRINSIC VISCOSITY OF POLYETHYLENE ADIPATE

[See figure 2]

\begin{tabular}{|c|c|c|c|c|}
\hline \multirow{2}{*}{$\begin{array}{c}\text { Dose, } \\
\text { megarep }\end{array}$} & \multicolumn{4}{|c|}{ Intrinsic viscosity, [n] } \\
\cline { 2 - 5 } & $\mathrm{A}$ & $\mathrm{B}$ & $\mathrm{c}$ & $\mathrm{D}$ \\
\hline 0 & $\mathrm{a}_{0.050}$ & $\mathrm{~b}_{0.248}$ & $\mathrm{c}_{0.274}$ & $\mathrm{~d}_{0.326}$ \\
5 & .056 & .193 & .248 & .247 \\
10 & .050 & .197 & .183 & .257 \\
25 & .068 & .178 & .214 & .205 \\
50 & .058 & .148 & .148 & .156 \\
100 & .060 & .130 & .187 & .203 \\
\hline
\end{tabular}

Polycondensation was performed:

at $250^{\circ} \mathrm{C}$ for $6 \mathrm{hr}$ at 1 atm.

$b_{\text {At }} 250^{\circ} \mathrm{C}$ for $6 \mathrm{hr}$ at $1 \mathrm{~atm}$, then for $5 \mathrm{hr}$ at $0.1 \mathrm{~mm}$.

cat $250^{\circ} \mathrm{C}$ for $5 \mathrm{hr}$ at $1 \mathrm{~atm}$, then for $10 \mathrm{hr}$ at $0.1 \mathrm{~mm}$.

d At $250^{\circ} \mathrm{C}$ for $6 \mathrm{hr}$ at 1 atm, then for $20 \mathrm{hr}$ at $0.3 \mathrm{~mm}$.

TABLE 7.- EFFECT OF IRRADIATION ON INTRTNSIC VISCOSITY OF POLYETHYLENE SEBACATE

[See flgure 4]

\begin{tabular}{|c|c|c|c|c|}
\hline \multirow{2}{*}{$\begin{array}{c}\text { Dose, } \\
\text { megarep }\end{array}$} & \multicolumn{4}{|c|}{ Intrinsic viscosity, [n] } \\
\cline { 2 - 5 } & $\mathrm{A}$ & $\mathrm{B}$ & $\mathrm{C}$ & $\mathrm{D}$ \\
\hline 0 & $\mathrm{a}_{0.161}$ & $\mathrm{~b}_{0.178}$ & $\mathrm{c}_{0.369}$ & $\mathrm{~d}_{0.464}$ \\
5 & .160 & .170 & .355 & .465 \\
10 & .162 & .171 & .350 & .365 \\
25 & .150 & .157 & .347 & .421 \\
50 & .142 & .148 & .323 & Gel \\
100 & .136 & .150 & .274 & Gel \\
\hline
\end{tabular}

Polycondensation was performed:

at $250^{\circ} \mathrm{C}$ for $6 \mathrm{hr}$ at 1 atm.

${ }^{b}$ At $250^{\circ} \mathrm{C}$ for $6 \mathrm{hr}$ at $1 \mathrm{~atm}$, then for $5 \mathrm{hr}$ at $0.5 \mathrm{Im}$.

cAt $250^{\circ} \mathrm{C}$ for $6 \mathrm{hr}$ at $1 \mathrm{~atm}$, then for $10 \mathrm{hr}$ at $0.7 \mathrm{~mm}$.

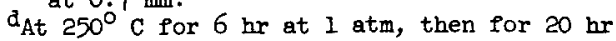
at $0.5 \mathrm{~mm}$. 
TABLE 8.- FFFECT OF IRRADIATIION ON INIRINSIC VISCOSITY OF POLYTRTMETHYLENE SUCCINATE [See figure 5]

\begin{tabular}{|c|c|c|c|}
\hline \multirow{2}{*}{$\begin{array}{c}\text { Dose, } \\
\text { megarep }\end{array}$} & \multicolumn{3}{|c|}{ Intrinsic viscosity, } \\
\cline { 2 - 4 } & A & B & c \\
\hline 0 & 00.090 & $b_{0.236}$ & ${ }^{0} 0.280$ \\
5 & .094 & .221 & Gel \\
10 & .094 & .206 & Gel \\
25 & .094 & .180 & Gel \\
50 & .094 & .164 & Gel \\
100 & .094 & Gel & Gel \\
\hline
\end{tabular}

Polycondensation was performed:

a At $250^{\circ} \mathrm{C}$ for $6 \mathrm{hr}$ at I atm.

b At $250^{\circ} \mathrm{C}$ for $5 \mathrm{hr}$ at $1 \mathrm{~atm}$, then for $10 \mathrm{hr}$ at $0.1 \mathrm{~mm}$.

c At $255^{\circ} \mathrm{C}$ for $6 \mathrm{hr}$ at $1 \mathrm{~atm}$, then for $20 \mathrm{hr}$ at $0.7 \mathrm{~mm}$.

TABLE 10.- EFFECT OF IRRADIATION ON INIRINSIC VISCOSITY OF POLYTRDMETHYLENE SEBACATTE [See figure 7]

\begin{tabular}{|c|c|c|c|c|}
\hline \multirow{2}{*}{$\begin{array}{c}\text { Dose, } \\
\text { megarep }\end{array}$} & \multicolumn{4}{|c|}{ Intringic viscosity, [ग] } \\
\hline & A & B & C & D \\
\hline 0 & $a_{0.145}$ & $b_{0} 0.148$ & $c_{0.207}$ & $d_{0} .496$ \\
\hline 5 & .138 & .248 & .196 & Gel \\
\hline 10 & .136 & .142 & .196 & Gel \\
\hline 25 & .136 & .140 & .200 & Gel \\
\hline 50 & .136 & .149 & .188 & Gel \\
\hline 100 & .134 & .148 & .180 & Gel \\
\hline
\end{tabular}

Polycondensation was performed:

$8_{\text {At }} 250^{\circ} \mathrm{C}$ for $6 \mathrm{hr}$ at $1 \mathrm{~atm}$.

bAt $240^{\circ} \mathrm{C}$ for $5 \mathrm{hr}$ at 1 atm, then for $5 \mathrm{hr}$ at $0.1 \mathrm{~mm}$.

cAt $240^{\circ} \mathrm{C}$ for $5 \mathrm{hr}$ at $1 \mathrm{~atm}$, then for $10 \mathrm{hr}$ at $0.1 \mathrm{~mm}$

dat $250^{\circ} \mathrm{c}$ for $6 \mathrm{hr}$ at 1 atm, then for $20 \mathrm{hr}$ at $0.1 \mathrm{~mm}$.
TABLE 9.- EFFECT OF IRRADIATION ON INTRINSIC

VISCOSITY OF POLYTRDMEIHYLERE ADIPATE

[See Plgure 6]

\begin{tabular}{|c|r|r|r|r|}
\hline \multirow{2}{*}{$\begin{array}{c}\text { Dose, } \\
\text { megarep }\end{array}$} & \multicolumn{4}{|c|}{ Intrins1c viscosity, $[\mathrm{T}]$} \\
\cline { 2 - 5 } & \multicolumn{1}{|c|}{$\mathrm{A}$} & \multicolumn{1}{c|}{ B } & \multicolumn{1}{c|}{$\mathrm{C}$} & \multicolumn{1}{c|}{$\mathrm{D}$} \\
\hline 0 & $0_{0.152}$ & $\mathrm{~b}_{0.200}$ & $\mathrm{c}_{0.251}$ & $\mathrm{a}_{0.291}$ \\
5 & .174 & .200 & .263 & .320 \\
10 & .190 & .197 & .275 & .330 \\
25 & .196 & .196 & $\mathrm{Gel}$ & $\mathrm{Gel}$ \\
50 & .202 & .187 & $\mathrm{Gel}$ & $\mathrm{Gel}$ \\
100 & .197 & .228 & $\mathrm{Gel}$ & $\mathrm{Gel}$ \\
\hline
\end{tabular}

Polycondensation was performed:

$a_{\text {At }} 250^{\circ} \mathrm{C}$ for $6 \mathrm{hr}$ at 1 atm.

$\mathrm{b}_{\text {At }} 250^{\circ} \mathrm{c}$ for $6 \mathrm{hr}$ at $1 \mathrm{~atm}$, then for $5 \mathrm{hr}$ at $0.2 \mathrm{~mm}$.

$c_{\text {At }} 250^{\circ} \mathrm{c}$ for $6 \mathrm{hr}$ at $1 \mathrm{~atm}$, then for $10 \mathrm{hr}$ at $1.5 \mathrm{~mm}$.

$\mathrm{d}_{\text {At }} 250^{\circ} \mathrm{C}$ for $6 \mathrm{hr}$ at $1 \mathrm{~atm}$, then for $20 \mathrm{hr}$ at $1.0 \mathrm{~mm}$.

TABLE 11.- EFFECT OF IRRADIATION ON INIRINSIC

VISCOSITY OF POLYTETRAMETHYLFNE SUCCINATIE

[See figure 8]

\begin{tabular}{|c|c|c|c|}
\hline \multirow{2}{*}{$\begin{array}{l}\text { Dose, } \\
\text { megarep }\end{array}$} & \multicolumn{3}{|c|}{ Intrinsic viscosity, $[\eta]$} \\
\hline & A & B & C \\
\hline 0 & ${ }^{8} 0.153$ & $b_{0} 0.239$ & $c_{0.378}$ \\
\hline 5 & .164 & Gel & .590 \\
\hline 10 & .151 & Gel & .630 \\
\hline 25 & .150 & Gel & Gel \\
\hline 50 & .143 & Gel & Gel \\
\hline 100 & .122 & Gel & Gel \\
\hline
\end{tabular}

Polycondensation was performed:

At $255^{\circ} \mathrm{C}$ for $5.5 \mathrm{hr}$ at I atm.

$b_{\text {At }} 240^{\circ} \mathrm{c}$ for $4 \mathrm{hr}$ at $1 \mathrm{~atm}$, then for $10 \mathrm{hr}$ at $0.5 \mathrm{nmon}$.

cAt $230^{\circ} \mathrm{C}$ for $4 \mathrm{hr}$ at I atm, then for $20 \mathrm{hr}$ at $0.1 \mathrm{~mm}$. 
TABLE 12.- EFFECT OF IRRADIATION ON INIRINSIC

VISCOSITY OF POLYTETRAMETHYLENE ADIPATE

[See figure 9]

\begin{tabular}{|c|c|c|c|}
\hline \multirow{2}{*}{$\begin{array}{c}\text { Dose, } \\
\text { megarep }\end{array}$} & \multicolumn{3}{|c|}{ Intrinsic v1scosity, $[\eta]$} \\
\cline { 2 - 4 } & A & B & c \\
\hline 0 & $a_{0.202}$ & $\mathrm{~b}_{0.262}$ & $\mathrm{c}_{0.343}$ \\
5 & .210 & .259 & $\mathrm{Gel}$ \\
10 & .215 & .259 & $\mathrm{Gel}$ \\
25 & .204 & .252 & $\mathrm{Gel}$ \\
50 & .210 & .235 & $\mathrm{Gel}$ \\
100 & .202 & .242 & $\mathrm{Gel}$ \\
\hline
\end{tabular}

Polycondensation was performed:

$a_{\text {At }} 250^{\circ} \mathrm{C}$ for $5 \mathrm{hr}$ at 1 atm.

$b_{\text {At }} 260^{\circ} \mathrm{C}$ for $5 \mathrm{hr}$ at I atm, then for $10 \mathrm{hr}$ at $0.1 \mathrm{~mm}$.

$c_{\text {At }} 225^{\circ} \mathrm{C}$ for $5 \mathrm{hr}$ at $1 \mathrm{~atm}$, then for $20 \mathrm{hr}$ at $0.4 \mathrm{~mm}$.

TABLE 14.- HTFECT OF IRRADIATION ON INIRINSIC

VISCOSITY OF POLYPENTAMETHYIENE SUCCINATE

[See flgure 11]

\begin{tabular}{|c|c|c|}
\hline \multirow{2}{*}{$\begin{array}{c}\text { Dose, } \\
\text { megarep }\end{array}$} & \multicolumn{2}{|c|}{ Intrinsic viscosity, [7] } \\
\cline { 2 - 3 } & A & B \\
\hline 0 & $a_{0.186}$ & $\mathrm{~b}_{0.190}$ \\
5 & .213 & .270 \\
10 & .276 & $\mathrm{Gel}$ \\
25 & $\mathrm{Gel}$ & $\mathrm{Gel}$ \\
50 & $\mathrm{Gel}$ & $\mathrm{Gel}$ \\
100 & $\mathrm{Gel}$ & $\mathrm{Gel}$ \\
\hline
\end{tabular}

Polycondensation was performed:

$a_{\text {At }} 245^{\circ} \mathrm{C}$ for $6 \mathrm{hr}$ at $1 \mathrm{~atm}$.

$\mathrm{b}_{\text {At }} 240^{\circ} \mathrm{c}$ for $5 \mathrm{hr}$ at $1 \mathrm{~atm}$, then for $20 \mathrm{hr}$ at $0.3 \mathrm{~mm}$.
TABLE 13.- FFFECT OF IRRADIATTION ON IMTRINSIC

VISCOSITY OF POLYTETRAMETHYLLENE SEBACATE

[See figure 10]

\begin{tabular}{|c|c|c|}
\hline \multirow{2}{*}{$\begin{array}{c}\text { Dose, } \\
\text { megarep }\end{array}$} & \multicolumn{2}{|c|}{ Intringic viscosity, $[\eta]$} \\
\cline { 2 - 3 } & $\mathrm{A}$ & $\mathrm{B}$ \\
\hline 0 & $\mathrm{a}_{0} .230$ & $\mathrm{~b}_{0} .258$ \\
5 & .248 & .548 \\
10 & .274 & $\mathrm{Gel}$ \\
25 & .274 & $\mathrm{Gel}$ \\
50 & .270 & $\mathrm{Gel}$ \\
100 & .282 & $\mathrm{Gel}$ \\
\hline
\end{tabular}

Polycondensation was performed:

at $255^{\circ} \mathrm{C}$ for $5.5 \mathrm{hr}$ at 1 atm.

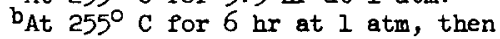
for $20 \mathrm{hr}$ at $1.0 \mathrm{~mm}$

TABLE 15.- HFFECT OF IRRADIATION ON INIRINSIC

VISCOSITY OF POLYPENTAMETHYLENE ADIPATE

[See figure 12]

\begin{tabular}{|c|c|c|c|}
\hline \multirow{2}{*}{$\begin{array}{c}\text { Dose, } \\
\text { megarep }\end{array}$} & \multicolumn{3}{|c|}{ Intrinsic viscosity,$[\eta]$} \\
\cline { 2 - 4 } & $\mathrm{A}$ & $\mathrm{B}$ & $\mathrm{C}$ \\
\hline 0 & $\mathrm{a}_{0.232}$ & $\mathrm{~b}_{0} .280$ & $\mathrm{c}_{0.338}$ \\
5 & .264 & .292 & .351 \\
10 & .268 & .290 & .363 \\
25 & .272 & .308 & $\mathrm{Gel}$ \\
50 & .274 & .330 & $\mathrm{Gel}$ \\
100 & $\mathrm{Gel}$ & $\mathrm{Gel}$ & $\mathrm{Gel}$ \\
\hline
\end{tabular}

Polycondensation was performed:

at $255^{\circ} \mathrm{C}$ for $5 \mathrm{hr}$ at 1 atm.

b At $250^{\circ} \mathrm{C}$ for $5 \mathrm{hr}$ at $1 \mathrm{~atm}$, then for $10 \mathrm{br}$ at $0.2 \mathrm{~mm}$.

$c_{\text {At }} 250^{\circ} \mathrm{C}$ for $5 \mathrm{hr}$ at $1 \mathrm{~atm}$, then for $15 \mathrm{hr}$ at $0.3 \mathrm{~m}$. 
TABLE 16.- EFTFECT OF IRRADIATION ON INURTISIC

VISCOSITY OF POLYPEMTAMETHYLENE AZELATE

[See figure 13]

\begin{tabular}{|c|c|c|}
\hline \multirow{2}{*}{$\begin{array}{l}\text { Dose, } \\
\text { megarep }\end{array}$} & \multicolumn{2}{|c|}{ Intrinsic viscosity, [ } \\
\hline & A & B \\
\hline 0 & 0.350 & $b_{0} .445$ \\
\hline 5 & .372 & .483 \\
\hline 10 & .418 & .534 \\
\hline 25 & Gel & Gel \\
\hline 50 & Gel & Gel \\
\hline 100 & Gel & Gel \\
\hline
\end{tabular}

Polycondensation was performed:

$a_{\text {At }} 250^{\circ} \mathrm{C}$ for $6 \mathrm{hr}$ at $1 \mathrm{~atm}$, then for 3 days at $0.2 \mathrm{~mm}$.

$\mathrm{b}_{\mathrm{At}} 250^{\circ} \mathrm{c}$ for $6 \mathrm{hr}$ at $1 \mathrm{~atm}$, then for 4 days at $0.2 \mathrm{~mm}$.
TABLE 17.- EFFECT OF IRRADIATION ON INTRLESIC VISCOSITY OF POLYPRMTAMEIHYLIRTE SEBACATIE

[See figure 14]

\begin{tabular}{|c|c|c|c|}
\hline \multirow{2}{*}{$\begin{array}{l}\text { Dose, } \\
\text { megarep }\end{array}$} & \multicolumn{3}{|c|}{ Intrinsic viscosity, $[\eta]$} \\
\hline & A & B & c \\
\hline 0 & $a_{0.237}$ & $b_{0} .264$ & 00.480 \\
\hline 5 & .222 & .340 & .474 \\
\hline 10 & .254 & .340 & .486 \\
\hline 25 & .220 & .364 & .518 \\
\hline 50 & .242 & Gel & $\mathrm{Gel}$ \\
\hline 100 & .234 & Gel & Gel \\
\hline
\end{tabular}

Polycondensation was performed:

$\mathbf{a}_{\text {At }} 25^{\circ} \mathrm{C}$ for $5.5 \mathrm{hr}$ at $1 \mathrm{~atm}$.

$b_{\text {At }} 265^{\circ} \mathrm{C}$ for $3 \mathrm{hr}$ at 1 atm, then for $9.5 \mathrm{hr}$ at $5 \mathrm{~mm}$.

cAt $250^{\circ} \mathrm{C}$ for $6 \mathrm{hr}$ at $1 \mathrm{~atm}$, then for $20 \mathrm{hr}$ at $0.05 \mathrm{~mm}$.

TABLE 18.- HFTFCT OF IRRADIATION ON IMIRIISIC

VISCOSITY OF POLYDECAMETEYLENE SEBACATTE

[See P1gure 15]

\begin{tabular}{|c|c|c|c|}
\hline \multirow{2}{*}{$\begin{array}{c}\text { Dose, } \\
\text { megarep }\end{array}$} & \multicolumn{3}{|c|}{ Intrinsic viscosity, [ ] ] } \\
\cline { 2 - 4 } & A & B & C \\
\hline 0 & 80.189 & $b_{0} .260$ & $c_{0.270}$ \\
5 & .185 & .324 & .326 \\
10 & .195 & .360 & .312 \\
25 & .213 & Gel & Gel \\
50 & .205 & Gel & Gel \\
100 & Gel & Gel & Gel \\
\hline
\end{tabular}

Polycondensation was performed:

$a_{\text {At }} 210^{\circ} \mathrm{C}$ for $6 \mathrm{hr}$ at $1 \mathrm{~atm}$.

bAt $210^{\circ} \mathrm{C}$ for $5 \mathrm{hr}$ at $1 \mathrm{~atm}$, then for $30 \mathrm{hr}$ at $0.5 \mathrm{~mm}$.

$c_{\text {At }} 210^{\circ} \mathrm{C}$ for $5 \mathrm{hr}$ at $1 \mathrm{~atm}$, then for $48 \mathrm{hr}$ at $0.5 \mathrm{~mm}$. 
TABLE 19.- EFFECT OF IRRADIATION ON INIRINSIC VISCOSITY OF POLY-1-METHYLETHYLENE SUCCINATE [See P1gure 16]

\begin{tabular}{|c|c|c|c|}
\hline \multirow{2}{*}{$\begin{array}{c}\text { Dose, } \\
\text { megarep }\end{array}$} & \multicolumn{3}{|c|}{ Intrinsic viscosity, [7] } \\
\cline { 2 - 4 } & $\mathrm{A}$ & $\mathrm{B}$ & $\mathrm{C}$ \\
\hline 0 & $\mathrm{a}_{0.108}$ & $\mathrm{~b}_{0.194}$ & $\mathrm{c}_{0.270}$ \\
5 & .156 & $\mathrm{Gel}$ & $\mathrm{Gel}$ \\
10 & .166 & $\mathrm{Gel}$ & $\mathrm{Gel}$ \\
25 & .129 & $\mathrm{Gel}$ & $\mathrm{Gel}$ \\
50 & .129 & $\mathrm{Gel}$ & $\mathrm{Gel}$ \\
100 & .082 & $\mathrm{Gel}$ & $\mathrm{Gel}$ \\
\hline
\end{tabular}

Polycondensation was performed:

at $220^{\circ} \mathrm{C}$ for $6 \mathrm{hr}$ at $1 \mathrm{~atm}$.

$b_{\text {At }} 220^{\circ} \mathrm{C}$ for $6 \mathrm{hr}$ at $1 \mathrm{~atm}$, then for 2 days at $0.3 \mathrm{~mm}$.

$c_{\text {At }} 220^{\circ} \mathrm{C}$ for $6 \mathrm{hr}$ at $1 \mathrm{~atm}$, then for 3 days at $0.3 \mathrm{~mm}$.

TABLE 21.- BFTFCT OF IRRADIATION ON INTRINSIC VISCOSITY OF POLY-1-METHYLETHYLENE AZWTATTE [See P1gure 18]

\begin{tabular}{|c|c|c|}
\hline \multirow{2}{*}{$\begin{array}{c}\text { Dose, } \\
\text { megarep }\end{array}$} & \multicolumn{2}{|c|}{ Intrinsic viscosity, $\quad[\eta]$} \\
\cline { 2 - 3 } & A & B \\
\hline 0 & 0.112 & $\mathrm{~b}_{0} .284$ \\
5 & .093 & .289 \\
10 & .078 & .314 \\
25 & .090 & Gel \\
50 & .129 & Gel \\
100 & .101 & Gel \\
\hline
\end{tabular}

Polycondensation was performed:

$a_{\text {At }} 220^{\circ} \mathrm{C}$ for $6 \mathrm{br}$ at $1 \mathrm{~atm}$.

$\mathrm{b}_{\text {At }} 220^{\circ} \mathrm{C}$ for $6 \mathrm{hr}$ at $1 \mathrm{~atm}$, then for 1 day at $0.3 \mathrm{~mm}$.
TABLE 20.- EFFECT OF IRRADIATION ON TNTRINSIC

VISCOSITY OF POLY-1-METEYLEIHYLIFNE ADIPATE

[See P1gure 17]

\begin{tabular}{|c|c|c|c|}
\hline \multirow{2}{*}{$\begin{array}{c}\text { Dose, } \\
\text { megarep }\end{array}$} & \multicolumn{3}{|c|}{ Intrinsic viscosity, [ ] ] } \\
\cline { 2 - 4 } & $\mathrm{A}$ & $\mathrm{B}$ & $\mathrm{C}$ \\
\hline 0 & 0.082 & $\mathrm{~b}_{0} .160$ & $\mathrm{c}_{0.284}$ \\
5 & .080 & .188 & .524 \\
10 & .079 & .222 & $\mathrm{Gel}$ \\
25 & .068 & .236 & $\mathrm{Gel}$ \\
50 & .074 & $\mathrm{Gel}$ & $\mathrm{Gel}$ \\
100 & .080 & $\mathrm{Gel}$ & $\mathrm{Gel}$ \\
\hline
\end{tabular}

Polycondensation was performed:

at $220^{\circ} \mathrm{C}$ for $6 \mathrm{hr}$ at $1 \mathrm{~atm}$

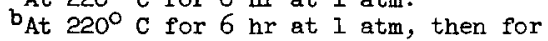
$I$ day at $0.3 \mathrm{~mm}$.

$c^{c}$ At $220^{\circ} \mathrm{C}$ for $6 \mathrm{hr}$ at $1 \mathrm{~atm}$, then for 2 days at $0.3 \mathrm{~mm}$.

TABLE 22.- EFFECT OF IRRADIATION ON INIRINSIC

VISCOSITY OF POLY-1-MEIHYLETHYIENE SEBACATE

[See figure 19]

\begin{tabular}{|c|c|c|c|}
\hline \multirow{2}{*}{$\begin{array}{c}\text { Dose, } \\
\text { megarep }\end{array}$} & \multicolumn{3}{|c|}{ Intrinsic viscosity, } \\
\cline { 2 - 4 } & $\mathrm{A}$ & $\mathrm{B}$ & $\mathrm{C}$ \\
\hline 0 & $\mathrm{a}_{0.238}$ & $\mathrm{~b}_{0} .338$ & $\mathrm{c}_{0.402}$ \\
5 & .235 & .450 & $\mathrm{Gel}$ \\
10 & .247 & $\mathrm{Gel}$ & $\mathrm{Gel}$ \\
25 & .253 & $\mathrm{Gel}$ & $\mathrm{Gel}$ \\
50 & $\mathrm{Gel}$ & $\mathrm{Gel}$ & $\mathrm{Gel}$ \\
100 & $\mathrm{Gel}$ & $\mathrm{Gel}$ & $\mathrm{Gel}$ \\
\hline
\end{tabular}

Polycondensation was performed:

$a_{\text {At }} 220^{\circ} \mathrm{C}$ for $6 \mathrm{hr}$ at 1 atm.

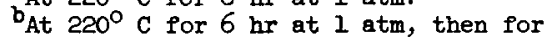
2 days at $0.3 \mathrm{~mm}$.

$c_{A t} 220^{\circ} \mathrm{C}$ for $6 \mathrm{hr}$ at $1 \mathrm{~atm}$, then for 3 days at $0.3 \mathrm{~mm}$. 
TABLE 23.- EFFECT OF IRRADIATION ON IMTRINSIC VISCOSITY OF POLY-2,2-DTMETHYLIRDIFTHYLANE SUCCINATIE [See Ilgure 20]

\begin{tabular}{|c|c|c|c|}
\hline \multirow{2}{*}{$\begin{array}{c}\text { Dose, } \\
\text { megarep }\end{array}$} & \multicolumn{3}{|c|}{ Intrinsic viscosity, [ ] ] } \\
\cline { 2 - 4 } & A & B & C \\
\hline 0 & 0.050 & $b_{0.310}$ & $c_{0.489}$ \\
5 & .061 & .275 & .451 \\
10 & .057 & .281 & .426 \\
25 & .054 & .250 & $\mathrm{Gel}$ \\
50 & .068 & .270 & $\mathrm{GeI}$ \\
100 & .053 & .316 & $\mathrm{Gel}$ \\
\hline
\end{tabular}

Polycondensation was performed:

at $220^{\circ} \mathrm{C}$ for $6 \mathrm{hr}$ at $1 \mathrm{~atm}$.

bat $220^{\circ} \mathrm{C}$ for $6 \mathrm{hr}$ at $1 \mathrm{~atm}$, then for 1 day at $0.3 \mathrm{~mm}$.

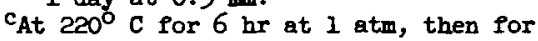
3 days at $0.3 \mathrm{~mm}$.
TABLE 24.- EFFECT OF IRRADIATION ON IFIRINSIC VISCOSTTY OF POLY-2,2-DIMETHYIIRDMETHYLFITE ADIPATTE

[See figure 21]

\begin{tabular}{|c|c|c|c|}
\hline \multirow{2}{*}{$\begin{array}{c}\text { Dose, } \\
\text { megarep }\end{array}$} & \multicolumn{3}{|c|}{ Intringic viscosity, [7] } \\
\cline { 2 - 4 } & $\mathrm{A}$ & $\mathrm{B}$ & $\mathrm{c}$ \\
\hline 0 & 0.069 & $\mathrm{~b}_{0} .213$ & $\mathrm{c}_{0.235}$ \\
5 & .065 & .204 & .245 \\
10 & .065 & .185 & .285 \\
25 & .055 & .214 & .310 \\
50 & .068 & $\mathrm{Gel}$ & $\mathrm{Gel}$ \\
100 & .053 & $\mathrm{Gel}$ & $\mathrm{Gel}$ \\
\hline
\end{tabular}

Polycondensation was performed:

${ }^{\text {at }} 220^{\circ} \mathrm{C}$ for $6 \mathrm{hr}$ at $1 \mathrm{~atm}$.

bAt $220^{\circ} \mathrm{C}$ for $6 \mathrm{hr}$ at $1 \mathrm{~atm}$, then for 2 days at $0.3 \mathrm{~mm}$.

$c_{\text {At } 220} \mathrm{C}$ for $6 \mathrm{hr}$ at $1 \mathrm{~atm}$, then for 3 days at $0.3 \mathrm{~mm}$.
TABLE 25.- EFFECT OF IRRADIATIOH ON INIRINSTC VISCOSTTY OF POLY-2,2-DTMETHYITRDMETHYIGIE AZETATE

[See figure 22]

\begin{tabular}{|c|c|c|c|}
\hline \multirow{2}{*}{$\begin{array}{c}\text { Dose, } \\
\text { megarep }\end{array}$} & \multicolumn{3}{|c|}{ Intrinsic viscosity, $[\eta]$} \\
\cline { 2 - 4 } & A & B & C \\
\hline 5 & 0.208 & $\mathrm{~b}_{0.412}$ & $\mathrm{c}_{0.582}$ \\
10 & .246 & .476 & .642 \\
25 & .220 & .666 & $\mathrm{Gel}$ \\
50 & .318 & $\mathrm{Gel}$ & $\mathrm{Gel}$ \\
100 & $\mathrm{Gel}$ & $\mathrm{Gel}$ & $\mathrm{Gel}$ \\
\hline
\end{tabular}

Polycondensation was performed:

aAt $220^{\circ} \mathrm{C}$ for $6 \mathrm{hr}$ at $1 \mathrm{~atm}$.

bAt $220^{\circ} \mathrm{C}$ for $6 \mathrm{hr}$ at $1 \mathrm{~atm}$, then for 1 day at $0.3 \mathrm{~mm}$.

cAt $220^{\circ} \mathrm{C}$ for $6 \mathrm{hr}$ at $1 \mathrm{~atm}$, then for 4 days at $0.3 \mathrm{~mm}$.
TABLE 26.- EFFECT OF IRRADIATION ON INIRINSIC VISCOSITY OF POLY-2,2-DIMETHYLTRIMETHYIENE SEBACATE

[See P1gure 23]

\begin{tabular}{|c|c|r|r|r|}
\hline \multirow{2}{*}{$\begin{array}{c}\text { Dose, } \\
\text { megarep }\end{array}$} & \multicolumn{4}{|c|}{ Intr1nsic viscosity, [7] } \\
\cline { 2 - 5 } & A & \multicolumn{1}{c|}{ B } & \multicolumn{1}{c|}{$c$} & \multicolumn{1}{c|}{$\mathrm{D}$} \\
\hline 0 & $\mathrm{a}_{0.110}$ & $\mathrm{~b}_{0.308}$ & $\mathrm{c}_{0.470}$ & $\mathrm{~d} 0.621$ \\
5 & .108 & .341 & .502 & .706 \\
10 & .114 & .428 & .560 & .738 \\
25 & .120 & $\mathrm{Gel}$ & $\mathrm{Gel}$ & $\mathrm{Gel}$ \\
50 & .132 & $\mathrm{Gel}$ & $\mathrm{Gel}$ & $\mathrm{Gel}$ \\
100 & .284 & $\mathrm{Gel}$ & $\mathrm{Gel}$ & $\mathrm{Gel}$ \\
\hline
\end{tabular}

Polycondengation was performed:

${ }^{\text {At }} 220^{\circ} \mathrm{C}$ for $6 \mathrm{hr}$ at $1 \mathrm{~atm}$.

$b_{\text {At }} 220^{\circ} \mathrm{C}$ for $6 \mathrm{hr}$ at $1 \mathrm{~atm}$, then for 1 day at $0.3 \mathrm{~mm}$.

$c_{\text {At }} 220^{\circ} \mathrm{C}$ for $6 \mathrm{hr}$ at $1 \mathrm{~atm}$, then for 3 days at $0.3 \mathrm{~mm}$.

$\mathrm{d}_{\text {At }} 220^{\circ} \mathrm{C}$ for $6 \mathrm{hr}$ at $1 \mathrm{~atm}$, then for 4 days at $0.3 \mathrm{~mm}$. 
TABLE 27.- EFFECT OF IRRADIATION ON INIRINSIC VISCOSITY OF POLY-2, 2-DIETEYLTRIMETHYLENE SUCCINATE [See flgure 24]

\begin{tabular}{|c|c|c|c|c|}
\hline \multirow{2}{*}{$\begin{array}{l}\text { Dose, } \\
\text { megarep }\end{array}$} & \multicolumn{4}{|c|}{ Intrinsic viscosity, $[\eta]$} \\
\hline & A & B & $c$ & D \\
\hline 0 & 80.098 & $b_{0.193}$ & $c_{0} .280$ & do. 385 \\
\hline 5 & .108 & .220 & .259 & .538 \\
\hline 10 & .120 & .246 & .275 & Gel \\
\hline 25 & .105 & .282 & .321 & Gel \\
\hline 50 & .082 & Gel & Gel & Gel \\
\hline 100 & .096 & Gel & Gel & Gel \\
\hline
\end{tabular}

Polycondensation was performed:

at $220^{\circ} \mathrm{C}$ for $10 \mathrm{hr}$ at $1 \mathrm{~atm}$.

$\mathrm{b}_{\text {At }} 220^{\circ} \mathrm{C}$ for $10 \mathrm{hr}$ at $1 \mathrm{~atm}$, then for 1 day at $0.5 \mathrm{~mm}$.

$c_{\text {At }} 220^{\circ} \mathrm{C}$ for $10 \mathrm{hr}$ at $1 \mathrm{~atm}$, then for 2 days at $0.5 \mathrm{~mm}$.

$d_{\text {At }} 220^{\circ} \mathrm{C}$ for $10 \mathrm{hr}$ at I atm, then for 4 days at $0.5 \mathrm{~mm}$.

TABLE 29.- EFFECT OF IRRADIATION ON INTRINSIC VISCOSITY OF POLY-2,2-DIETHYIIRIMEITHYLENE AZELATEE [See pigure 26]

\begin{tabular}{|c|c|c|c|}
\hline \multirow{2}{*}{$\begin{array}{l}\text { Dose } \\
\text { megarep }\end{array}$} & \multicolumn{3}{|c|}{ Intringle viscosity, [n] } \\
\hline & $A$ & B & C \\
\hline 0 & $a_{0.166}$ & $b_{0} 0.240$ & $c_{0} 0.246$ \\
\hline 5 & .166 & .278 & .240 \\
\hline 10 & .166 & .268 & .239 \\
\hline 25 & .164 & .301 & .284 \\
\hline 50 & .184 & GeI & GeI \\
\hline 100 & Gel & GeI & Gel \\
\hline
\end{tabular}

Polycondensation was performed:

$a_{\text {At }} 200^{\circ} \mathrm{C}$ for $12 \mathrm{hr}$ at 1 atm.

$\mathrm{b}_{\text {At }} 220^{\circ} \mathrm{C}$ for $10 \mathrm{hr}$ at $1 \mathrm{~atm}$, then for 2 days at $0.5 \mathrm{~mm}$.

$\mathrm{c}_{\text {At }} 220^{\circ} \mathrm{C}$ for $10 \mathrm{hr}$ at $1 \mathrm{~atm}$, then for 3 days at $0.5 \mathrm{~mm}$.
TABLE 28.- EF'FECT OF IRRADIATION ON INTRINSIC VISCOSITY OF POLY-2,2-DIETHYITRIMETHYLENE ADIPATE [See figure 25]

\begin{tabular}{|c|c|c|c|}
\hline \multirow{2}{*}{$\begin{array}{l}\text { Dose, } \\
\text { megarep }\end{array}$} & \multicolumn{3}{|c|}{ Intringlc viscosity, $[\eta]$} \\
\hline & A & B & $\mathrm{C}$ \\
\hline 0 & 80.100 & $b_{0} .128$ & $c_{0} .154$ \\
\hline 5 & .099 & .158 & .173 \\
\hline 10 & .094 & .244 & .180 \\
\hline 25 & .110 & .160 & .184 \\
\hline 50 & .204 & .182 & .224 \\
\hline 100 & .115 & Gel & Gel \\
\hline
\end{tabular}

Polycondensation was performed:

$a_{\text {At }} 20^{\circ} \mathrm{C}$ for $10 \mathrm{hr}$ at $1 \mathrm{~atm}$.

$\mathrm{b}_{\mathrm{At}} 220^{\circ} \mathrm{C}$ for $10 \mathrm{hr}$ at $\mathrm{l} \mathrm{atm}$, then for 3 days at $0.5 \mathrm{~mm}$.

$c_{\text {At }} 210^{\circ} \mathrm{C}$ for $12 \mathrm{hr}$ at $1 \mathrm{~atm}$, then for 3 days at $0.3 \mathrm{mon}$.

TABLE 30.- EFFECT OF IRRADIATTON ON INTRINSIC VISCOSITYY OF POLY-2,2-DIETHYLTRMMETHYLENE SEBACATE [See flgure 27]

\begin{tabular}{|c|c|c|c|}
\hline \multirow{2}{*}{$\begin{array}{c}\text { Dose, } \\
\text { megarep }\end{array}$} & \multicolumn{3}{|c|}{ Intring1c viscosity, [n] } \\
\cline { 2 - 4 } & $\mathrm{A}$ & $\mathrm{B}$ & $\mathrm{c}$ \\
\hline 0 & $\mathrm{a}_{0.198}$ & $\mathrm{~b}_{0.191}$ & $\mathrm{c}_{0.230}$ \\
5 & .184 & .221 & .240 \\
10 & .186 & .209 & .208 \\
25 & .204 & .192 & .459 \\
50 & .274 & Gel & Gel \\
100 & Gel & Gel & Gel \\
\hline
\end{tabular}

Polycondensation was performed:

at $220^{\circ} \mathrm{C}$ for $6 \mathrm{hr}$ at $1 \mathrm{~atm}$

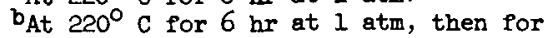
2 days at $0.3 \mathrm{~mm}$.

c At $220^{\circ} \mathrm{c}$ for $6 \mathrm{hr}$ at 1 atm, then for 4 days at $0.3 \mathrm{~mm}$. 
TARLE 31.- EFFBCT OF IRRADIATHON OII IRTRTISIC VISCOSITY OF POLY-3-MESHYLPETTAMETHTIJWE SUCCITATE [See Pigure 28]

\begin{tabular}{|c|c|c|c|}
\hline \multirow{2}{*}{$\begin{array}{c}\text { Dose, } \\
\text { megarep }\end{array}$} & \multicolumn{3}{|c|}{ Intringic viscosity, [n] } \\
\cline { 2 - 4 } & A & B & C \\
\hline 0 & 0.151 & $\mathrm{~b}_{0.189}$ & $\mathbf{c} 0.375$ \\
5 & .140 & .196 & .412 \\
10 & .155 & .217 & .486 \\
25 & .183 & .220 & Gel \\
50 & .194 & .239 & Gel \\
100 & Gel & Gel & Gel \\
\hline
\end{tabular}

Polycondensation was performed:

At $220^{\circ} \mathrm{C}$ for $12 \mathrm{hr}$ at $1 \mathrm{~atm}$.

$\mathrm{b}_{\text {At }} 220^{\circ} \mathrm{C}$ for $12 \mathrm{hr}$ at $1 \mathrm{~atm}$, then for 1 day at $0.3 \mathrm{~mm}$.

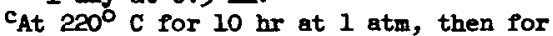
4 days at $0.5 \mathrm{~mm}$.

TABLIT 33.- BHFBCT OF IRRADIATION ON IFIRTNSIC VISCOSTMY

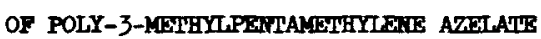

[See figure 30 ]

\begin{tabular}{|c|c|c|c|}
\hline \multirow{2}{*}{$\begin{array}{c}\text { Dose, } \\
\text { megarep }\end{array}$} & \multicolumn{3}{|c|}{ Intringic viscosity, $[\eta]$} \\
\cline { 2 - 4 } & A & B & C \\
\hline 0 & 0.195 & $b_{0} .244$ & $c_{0.388}$ \\
5 & .183 & .240 & .431 \\
10 & .203 & .248 & .462 \\
25 & .207 & .248 & Gel \\
50 & Gel & .354 & Gel \\
100 & Gel & Gel & Gel \\
\hline
\end{tabular}

Polycondensation was performed:

$a_{\text {At }} 220^{\circ} \mathrm{c}$ for $6 \mathrm{hr}$ at 1 atm.

bAt $220^{\circ} \mathrm{c}$ for $6 \mathrm{hr}$ at 1 atm, then for 1 day at $0.3 \mathrm{~mm}$.

cAt $220^{\circ} \mathrm{c}$ for $6 \mathrm{hr}$ at $\mathrm{l} \mathrm{atm,} \mathrm{then} \mathrm{for}$ 3 days at $0.3 \mathrm{~mm}$.
TABLE 32.- EFFFCT OF IRRADIATION ON IFIRIISIC VISCOSITY

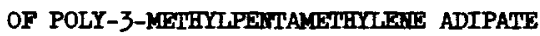
[See figure 29]

\begin{tabular}{|c|c|c|c|}
\hline \multirow{2}{*}{$\begin{array}{l}\text { Dose, } \\
\text { megarep }\end{array}$} & \multicolumn{3}{|c|}{ Intring1c viscosity, $[\eta]$} \\
\hline & $\mathbf{A}$ & B & c \\
\hline 0 & 80.248 & $b_{0} .318$ & $\infty .343$ \\
\hline 5 & .232 & .316 & .482 \\
\hline 10 & .212 & .289 & .642 \\
\hline 25 & .259 & .297 & Gel \\
\hline 50 & .310 & .342 & Gel \\
\hline 100 & GeI & Gel & Gel \\
\hline
\end{tabular}

Polycondensation was performed:

at $220^{\circ} \mathrm{C}$ for $5 \mathrm{hr}$ at $1 \mathrm{~atm}$, then for $12 \mathrm{hr}$ at $0.3 \mathrm{~mm}$.

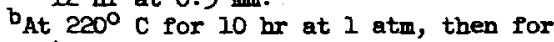
4 days at $0.3 \mathrm{man}$.

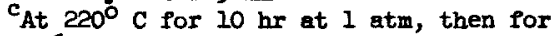
6 days at $0.3 \mathrm{~mm}$.

TABLI 34.- EFFECT OF IRRADTATIOI OI IRIRINSIC VISCOSITY

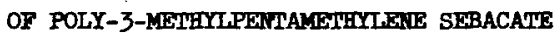
[See figure 31]

\begin{tabular}{|c|c|c|c|}
\hline \multirow{2}{*}{$\begin{array}{l}\text { Dose, } \\
\text { megarep }\end{array}$} & \multicolumn{3}{|c|}{ Intrinsic viscosity, [n] } \\
\hline & A & B & c \\
\hline 0 & ${ }^{80} 0.244$ & $b_{0.262}$ & $c_{0.332}$ \\
\hline 5 & .269 & $.264^{\circ}$ & .365 \\
\hline 10 & .250 & .294 & .388 \\
\hline 25 & .282 & .298 & .467 \\
\hline 50 & .313 & .339 & Gel \\
\hline 100 & Gel & Gel & Gel \\
\hline
\end{tabular}

Polycondensation was performed:

$\mathrm{a}_{\text {At }} 220^{\circ} \mathrm{C}$ for $10 \mathrm{hr}$ at I atm.

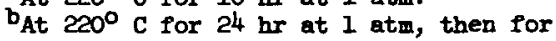
$12 \mathrm{hr}$ at $0.3 \mathrm{~mm}$.

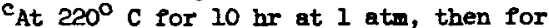
$24 \mathrm{hr}$ at $0.5 \mathrm{~mm}$. 
TABLE 35. - EFFECT OF IRRADIATTION ON INIRINSIC VISCOSITY OF POLYPENTAMETHYLENE-2,3-DIPHENYI SUCCINATE

$$
\text { [See figure 32] }
$$

\begin{tabular}{|c|c|c|}
\hline \multirow{2}{*}{$\begin{array}{c}\text { Dose, } \\
\text { megarep }\end{array}$} & \multicolumn{2}{|c|}{ Intrinsic viscosity, [ך] } \\
\cline { 2 - 3 } & $\mathrm{A}$ & $\mathrm{B}$ \\
\hline 0 & $\mathrm{a} 0.126$ & $\mathrm{~b}_{0.242}$ \\
5 & .120 & .240 \\
10 & .110 & .246 \\
15 & .123 & .246 \\
20 & .099 & .244 \\
25 & .113 & .245 \\
\hline
\end{tabular}

Polycondensation was performed:

$a_{\text {At }} 240^{\circ} \mathrm{C}$ for $6 \mathrm{hr}$ at 1 atm.

bat $240^{\circ} \mathrm{C}$ for $5 \mathrm{hr}$ at $1 \mathrm{~atm}$, then for 2 days at $0.3 \mathrm{~mm}$.
TABLE 36.- HFFECT OF IRRADIATTON ON IMTRINSIC VISCOSITY OF POLY-3-METHYLPENTAMETHYLENE-3-METHYL ADIPATE

[See figure 33]

\begin{tabular}{|c|c|c|}
\hline \multirow{2}{*}{$\begin{array}{c}\text { Dose } \\
\text { megarep }\end{array}$} & \multicolumn{2}{|c|}{ Intrinsic viscosity, $[\eta]$} \\
\cline { 2 - 3 } & $\mathrm{A}$ & $\mathrm{B}$ \\
\hline 0 & $\mathrm{a}_{0} .150$ & $\mathrm{~b}_{0.294}$ \\
5 & .160 & .308 \\
10 & .150 & .288 \\
15 & .152 & .278 \\
20 & .148 & .274 \\
25 & .138 & .270 \\
\hline
\end{tabular}

Polycondensation was performed:

${ }^{8}$ At $220^{\circ} \mathrm{C}$ for $6 \mathrm{hr}$ at 1 atm.

${ }^{b}$ At $200^{\circ} \mathrm{C}$ for $6 \mathrm{hr}$ at 1 atm, then for 3 days at $0.3 \mathrm{~mm}$.
TABLE 37.- EFFECT OF IRRADIATIION ON INTRINSIC VISCOSITY OF POLY-2,2-DIMETHYIIRIMETHYLENE-3,3-DIMETHYL GLUTARATE [See figure 34]

\begin{tabular}{|c|c|c|}
\hline \multirow{2}{*}{$\begin{array}{c}\text { Dose, } \\
\text { megarep }\end{array}$} & \multicolumn{2}{|c|}{ Intrinsic viscosity, $[\eta]$} \\
\hline & A & B \\
\hline 0 & $a_{0.045}$ & $\mathrm{~b}_{0} 0.232$ \\
\hline 5 & .040 & .228 \\
\hline 10 & .038 & .224 \\
\hline 15 & .041 & .230 \\
\hline 20 & .051 & .235 \\
\hline 25 & .060 & .238 \\
\hline
\end{tabular}

Polycondensation was performed:

$a_{\text {At }} 220^{\circ} \mathrm{C}$ for $6 \mathrm{hr}$ at $1 \mathrm{~atm}$.

$b_{\text {At }} 220^{\circ} \mathrm{C}$ for $6 \mathrm{hr}$ at $1 \mathrm{~atm}$, then for 2 days at $0.3 \mathrm{~mm}$.
TABLE 38. - HFFECT OF IRRADIATION ON INITRINSIC VISCOSITY OF POLYPENTTAMETHYLENE-2-METHYL SUCCINATE

[See figure 35]

\begin{tabular}{|c|c|c|}
\hline \multirow{2}{*}{$\begin{array}{c}\text { Dose, } \\
\text { megarep }\end{array}$} & \multicolumn{2}{|c|}{ Intrins1c v1scosity, $[\eta]$} \\
\cline { 2 - 3 } & $\mathrm{A}$ & $\mathrm{B}$ \\
\hline 0 & 0.146 & $\mathrm{~b}_{0} .184$ \\
5 & .140 & .186 \\
10 & .142 & .189 \\
25 & .138 & .183 \\
50 & .158 & .200 \\
100 & .156 & .261 \\
\hline
\end{tabular}

Polycondensation was performed:

$a_{\text {At }} 220^{\circ} \mathrm{C}$ for $6 \mathrm{hr}$ at $1 \mathrm{~atm}$.

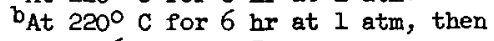
for $6 \mathrm{hr}$ at $0.5 \mathrm{~mm}$. 
TABLE 39.- EFFECT OF DOSE RATE AND SOURCE ON INIRINSIC VISCOSITY

OF POLYTEIRAMEITYIENE SEBACATE

[See Pigure 36]

\begin{tabular}{|c|c|c|}
\hline Source of irradiation & $\begin{array}{l}\text { Dose, } \\
\text { megarep }\end{array}$ & $\begin{array}{l}\text { Intrinsic } \\
\text { viscosity }\end{array}$ \\
\hline Cobalt 60 & $\begin{array}{l}0 \\
2.0 \\
3.0 \\
4.2 \\
6.0\end{array}$ & $\begin{array}{l}0.340 \\
.375 \\
.410 \\
.475 \\
\text { Gel }\end{array}$ \\
\hline $\begin{array}{l}\text { Van de Graaff ( } 2 \mathrm{MeV} \text { ) } \\
\text { At } 50 \text { mi croamperes } \\
\text { At } 100 \text { microamperes } \\
\text { At } 25 \text { microamperes } \\
\text { At } 25 \text { microamperes }\end{array}$ & $\begin{array}{l}0 \\
2.0 \\
4.0 \\
5.0 \\
6.0\end{array}$ & $\begin{array}{l}.340 \\
.378 \\
.470 \\
.536 \\
\text { Gel }\end{array}$ \\
\hline $\begin{array}{c}\text { ARCO accelerator ( } 8 \mathrm{MeV}) \\
\text { At } 50 \text { milliamperes } \\
\text { At } 50 \text { milliamperes } \\
\text { At } 50 \text { milliamperes }\end{array}$ & $\begin{array}{l}0 \\
2.0 \\
3.8 \\
5.8\end{array}$ & $\begin{array}{l}.340 \\
.376 \\
.472 \\
\text { Gel }\end{array}$ \\
\hline
\end{tabular}

TABLE 40.- EFFECT OF AIR PRESSURE AND FIIM THICKNESS ON TNTRINSIC VISCOSITY

OF POLYTIETRAMETHYIENE SEBACATE

[See P1gure 37]

\begin{tabular}{|c|c|c|c|c|}
\hline Film & $\begin{array}{c}\text { Thickness, } \\
\text { mam }\end{array}$ & $\underset{\substack{\text { Alr } \\
\text { pressure, }}}{ }$ & $\begin{array}{l}\text { Dose, } \\
\text { megarep }\end{array}$ & [n] \\
\hline A & 0.10 & 760 & $\begin{array}{l}0 \\
2.0 \\
4.0 \\
6.0\end{array}$ & $\begin{array}{r}0.340 \\
.300 \\
.285 \\
.281\end{array}$ \\
\hline B & .25 & 760 & $\begin{array}{l}0 \\
3.0 \\
4.0 \\
5.4\end{array}$ & $\begin{array}{l}.340 \\
.320 \\
.315 \\
.315\end{array}$ \\
\hline C & 2.00 & 760 & $\begin{array}{l}0 \\
2.3 \\
4.0 \\
4.8 \\
5.8\end{array}$ & $\begin{array}{l}.340 \\
.340 \\
.368 \\
.390 \\
.460\end{array}$ \\
\hline D & .25 & 2.00 & $\begin{array}{l}0 \\
2.3 \\
4.0 \\
5.0 \\
6.0\end{array}$ & $\begin{array}{r}.340 \\
.350 \\
.382 \\
.428 \\
.497\end{array}$ \\
\hline $\mathbf{E}$ & 2.00 & 2.00 & $\begin{array}{l}0 \\
2.0 \\
4.0 \\
5.0 \\
6.0\end{array}$ & $\begin{array}{l}.340 \\
.350 \\
.395 \\
.454 \\
.521\end{array}$ \\
\hline $\mathbf{F}$ & 2.00 & $5 \times 10^{-6}$ & $\begin{array}{l}0 \\
2.0 \\
3.0 \\
4.4 \\
6.0\end{array}$ & $\begin{array}{l}.340 \\
.375 \\
.411 \\
.475 \\
\text { Gel }\end{array}$ \\
\hline
\end{tabular}


TABLE 41.- EFHECT OF ORTENTATION ON INIRINSIC VISCOSITY OF POLYTETRAMEIHYULENE SEBACAIIE [See figure 38]

\begin{tabular}{|c|c|}
\hline $\begin{array}{c}\text { Dose, } \\
\text { megarep }\end{array}$ & [7] \\
\hline \multicolumn{2}{|c|}{ Unoriented filaments } \\
\hline $\begin{array}{r}0 \\
2 \\
3 \\
4 \\
5 \\
7 \\
10\end{array}$ & $\begin{array}{l}0.358 \\
.410 \\
.440 \\
.512 \\
.648 \\
\text { Gel } \\
\text { Gel }\end{array}$ \\
\hline \multicolumn{2}{|c|}{ oriented fllaments } \\
\hline $\begin{array}{r}0 \\
3 \\
5 \\
7 \\
10 \\
13\end{array}$ & $\begin{array}{r}0.358 \\
.420 \\
.462 \\
.521 \\
.607 \\
\text { Gel }\end{array}$ \\
\hline \multicolumn{2}{|c|}{ Melted polymer } \\
\hline $\begin{array}{l}0 \\
4 \\
6\end{array}$ & $\begin{array}{c}0.358 \\
\text { Gel } \\
\text { Gel }\end{array}$ \\
\hline
\end{tabular}

TABLE 43. - LOSS IN WEIGHT OF POLYTETRAMETHYLENE SEBACAIE POLMMER ${ }^{a}$ DUE TO IRRADIATION

\begin{tabular}{|c|c|c|c|}
\hline \multirow{2}{*}{$\begin{array}{c}\text { Film } \\
\text { thickness } \\
\text { mm }\end{array}$} & \multirow{2}{*}{$\begin{array}{l}\text { Dose, } \\
\text { mega- } \\
\text { rep }\end{array}$} & \multicolumn{2}{|c|}{ Welght loss, percent } \\
\hline & & $\begin{array}{c}\text { After } \\
\text { Irradiation }\end{array}$ & $\begin{array}{l}\text { After post- } \\
\text { evacuation }\end{array}$ \\
\hline 0.25 & $\left\{\begin{array}{l}1 \\
5 \\
20\end{array}\right.$ & $\begin{array}{l}1.5 \\
3.0 \\
4.8\end{array}$ & $\begin{array}{l}1.52 \\
3.16 \\
4.92\end{array}$ \\
\hline .50 & $\left\{\begin{array}{r}1 \\
5 \\
20\end{array}\right.$ & $\begin{array}{r}.8 \\
1.5 \\
1.8\end{array}$ & $\begin{array}{l}1.1 \\
1.7 \\
2.01\end{array}$ \\
\hline .75 & $\left\{\begin{array}{l}1 \\
5 \\
20\end{array}\right.$ & $\begin{array}{l}.1 \\
.6 \\
.9\end{array}$ & $\begin{array}{r}.63 \\
1.20 \\
1.84\end{array}$ \\
\hline
\end{tabular}

$[\eta]=0.340$.
TABLE 42.- EFFECT OF HEATING IRRADIAT'ED POLYTLETRAMETHYRERIE SEBACATTE [See f1gure 39]

\begin{tabular}{|c|c|}
\hline $\begin{array}{l}\text { Hours heated at } \\
68^{\circ} \mathrm{C} \text { in vacuo }\end{array}$ & {$[\eta]$} \\
\hline \multicolumn{2}{|c|}{ Unoriented f1laments } \\
\hline $\begin{array}{r}0 \\
5 \\
15 \\
25 \\
30 \\
45\end{array}$ & $\begin{array}{r}0.440 \\
.445 \\
.451 \\
.454 \\
.454 \\
.454\end{array}$ \\
\hline \multicolumn{2}{|c|}{ Orlented filaments } \\
\hline $\begin{array}{r}0 \\
5 \\
10 \\
15 \\
25 \\
30 \\
45\end{array}$ & $\begin{array}{r}0.420 \\
.431 \\
.437 \\
.441 \\
.444 \\
.446 \\
.446\end{array}$ \\
\hline
\end{tabular}

aDosage: 3 megareps, at pressure of $1 \times 10^{-7}$ in $\mathrm{Hg}$.

TABLE 44. - ELEMENTAL ANALYSES OF POLYESTERS BEFORE AND AFTER IRRADIATION

\begin{tabular}{|c|c|c|c|c|c|}
\hline \multirow[b]{2}{*}{ Polymer } & \multicolumn{5}{|c|}{ Elemental analyses, percent } \\
\hline & $\begin{array}{l}\text { Ele- } \\
\text { ment }\end{array}$ & $\begin{array}{c}\text { Theoret- } \\
\text { ical }\end{array}$ & $\begin{array}{c}\text { Before } \\
\text { Irradia- } \\
\text { tion }\end{array}$ & $\begin{array}{l}\text { After } \\
\text { irradia- } \\
\text { tion at } \\
10^{-7} \mathrm{~mm}\end{array}$ & $\begin{array}{l}\text { After } \\
\text { irradia- } \\
\text { tion in } \\
\quad \text { air }\end{array}$ \\
\hline $\begin{array}{l}\text { Polytetramethylene } \\
\text { sebacate }([\eta]=0.340 ; \\
\text { dose, } 400 \text { megareps })\end{array}$ & $\begin{array}{l}\mathrm{C} \\
\mathrm{H} \\
\mathrm{O}\end{array}$ & $\begin{array}{r}65.62 \\
9.36 \\
25.01\end{array}$ & $\begin{array}{r}65.64 \\
9.33 \\
25.10\end{array}$ & $\begin{array}{r}65.68 \\
9.56 \\
24.76\end{array}$ & $\begin{array}{r}60.27 \\
8.67 \\
31.06\end{array}$ \\
\hline $\begin{array}{l}\text { Polyethylene succinate } \\
\qquad(\eta]=0.326 ; \text { dose, } \\
50 \text { megareps })\end{array}$ & $\begin{array}{l}\text { C } \\
\text { H } \\
\text { O }\end{array}$ & $\begin{array}{r}50.00 \\
5.55 \\
44.45\end{array}$ & $\begin{array}{r}49.97 \\
5.51 \\
44.52\end{array}$ & $\begin{array}{r}51.17 \\
5.91 \\
42.92\end{array}$ & $\begin{array}{r}45.65 \\
5.18 \\
49.17\end{array}$ \\
\hline
\end{tabular}


TABLE 45.- GASES FROM IRRADIATION OF POLMERS AND REFFEREITE CONPOUEDS

\begin{tabular}{|c|c|c|c|c|c|c|}
\hline \multirow{2}{*}{ Substance } & \multirow{2}{*}{$\begin{array}{c}\text { Dose, } \\
\text { mega- } \\
\text { rep }\end{array}$} & \multicolumn{5}{|c|}{ Gas, mole percent } \\
\hline & & $\mathrm{H}_{2}$ & $\mathrm{CO}$ & $\mathrm{CO}_{2}$ & $\begin{array}{l}\text { RH } \\
\text { (a) }\end{array}$ & $\begin{array}{c}\text { Other } \\
\text { (b) }\end{array}$ \\
\hline Polyethylene succinate, $c[\eta]=0.326$ & 50 & 44.0 & 26.5 & 9.7 & $\mathrm{~d}_{7.4}$ & 22.4 \\
\hline Polytetramethylene sebacate, $c[\eta]=0.340$ & 4 & 49.2 & 26.6 & 17.1 & 4.98 & 3.12 \\
\hline Polytetramethylene sebacate, $c[\eta]]=0.340$ & 22 & 49.6 & 26.2 & 18.0 & 4.00 & 2.2 \\
\hline Polydecamethylene sebacate, $c[\eta]=0.270$ & 10 & 61.9 & 14.8 & 13.6 & 5.8 & 3.9 \\
\hline Polymethyl methacrylate (ref. 26) & 22 & 44.1 & 22.8 & 18.8 & 6.0 & e8.3 \\
\hline Caprylic ac1d (refs. 27 and 28 ) & -- & 33.0 & 9.0 & 51.0 & (f) & 7.0 \\
\hline Sebacic ac1d (refs. 27 and 28 ) & 92 & 26.3 & 2.1 & 68.9 & (f) & 2.7 \\
\hline Cetyl paimitate (refs. 27 and 28) & -- & 85.0 & 3.0 & 4.0 & 3.6 & 4.4 \\
\hline
\end{tabular}

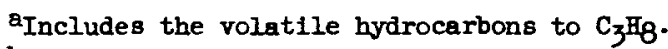

bIncludes $\mathrm{E}_{2} \mathrm{O}$, higher hydrocarbons, $\mathrm{O}_{2}, \mathrm{H}_{2}$, and so forth.

co.1-gram samples, $0.25 \mathrm{~mm}$ thick.

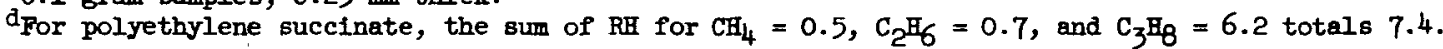

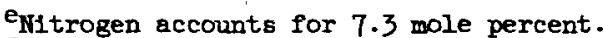

$f_{R H}$ value included in "other."

TABLE 46. - INIRINSIC VISCOSITY OF MIXIURES OF

POLYTETRAMETHYIENE SEBACATE AFD DIVINYLBENZENCE

[See Pigure 40]

\begin{tabular}{|c|c|c|c|c|}
\hline $\begin{array}{c}\text { Polymer } \\
\text { weilght, } \\
\text { gram }\end{array}$ & $\begin{array}{c}\text { Divinyl- } \\
\text { benzene } \\
\text { welght, } \\
\text { gram }\end{array}$ & $\begin{array}{l}\text { Actual } \\
\text { divinyl- } \\
\text { benzene } \\
\text { welght, } \\
\text { percent }\end{array}$ & $\begin{array}{c}\text { Dose, } \\
\text { mega- } \\
\text { rep }\end{array}$ & [7] \\
\hline 100 & 0 & 0 & $\left(\begin{array}{l}0 \\
.5 \\
1.0 \\
2.0\end{array}\right.$ & $\begin{array}{r}0.340 \\
.345 \\
.354 \\
.375\end{array}$ \\
\hline 99.5 & 1.1 & .497 & $\left\{\begin{array}{l}0 \\
.5 \\
1.0 \\
2.0\end{array}\right.$ & $\begin{array}{l}.340 \\
.347 \\
.357 \\
.383\end{array}$ \\
\hline 99.0 & 2.0 & .990 & $\left\{\begin{array}{l}0 \\
.5 \\
1.5 \\
2.0\end{array}\right.$ & $\begin{array}{l}.339 \\
.348 \\
.374 \\
.391\end{array}$ \\
\hline 96.0 & 8.0 & $3.7^{4}$ & $\left\{\begin{array}{l}0 \\
.5 \\
1.0 \\
1.5 \\
2.0\end{array}\right.$ & $\begin{array}{l}.337 \\
.349 \\
.364 \\
.384 \\
.403\end{array}$ \\
\hline 90.0 & 20.0 & 9.09 & $\left\{\begin{array}{l}0 \\
.25 \\
.50 \\
.75 \\
1.00 \\
1.25 \\
1.50 \\
1.75\end{array}\right.$ & $\begin{array}{l}.336 \\
.338 \\
.325 \\
.327 \\
.330 \\
.335 \\
.339 \\
.344\end{array}$ \\
\hline
\end{tabular}


TABLE 47. - EFFECT OF IRRADIATION ON SOLUBILITY OF MIXTURES

OF POLYTETRAMETHYIFIE SEBACATE AND DIVINYLBENZENE

[See f1gure 41]

\begin{tabular}{|c|c|c|c|c|}
\hline $\begin{array}{l}\text { Polymer } \\
\text { welght, } \\
\text { gram }\end{array}$ & $\begin{array}{c}\text { Divinylbenzene } \\
\text { welght, } \\
\text { gram }\end{array}$ & $\begin{array}{c}\text { Actual } \\
\text { divinylbenzene } \\
\text { weight, } \\
\text { percent }\end{array}$ & $\begin{array}{l}\text { Dose, } \\
\text { megarep }\end{array}$ & $\begin{array}{l}\text { Welght } \\
\text { extracted, } \\
\text { percent }\end{array}$ \\
\hline 100 & 0 & 0 & {$\left[\begin{array}{r}4 \\
12 \\
30 \\
50 \\
60\end{array}\right.$} & $\begin{array}{r}100 \\
79 \\
59 \\
44 \\
38\end{array}$ \\
\hline 99.5 & 1.1 & .497 & $\left\{\begin{array}{l}4 \\
16 \\
37 \\
50\end{array}\right.$ & $\begin{array}{l}95 \\
69.6 \\
45 \\
35.1\end{array}$ \\
\hline 99.0 & 2 & .99 & $\left\{\begin{array}{l}4 \\
20 \\
36 \\
49\end{array}\right.$ & $\begin{array}{l}76.1 \\
53.5 \\
39.1 \\
29\end{array}$ \\
\hline 96.0 & 8 & 3.74 & $\left\{\begin{array}{c}4 \\
8.5 \\
25 \\
40 \\
45 \\
50\end{array}\right.$ & $\begin{array}{l}71 \\
62 \\
43 \\
29 \\
26 \\
23\end{array}$ \\
\hline 90.0 & 20 & 9.09 & $\left\{\begin{array}{l}4 \\
7.3 \\
13 \\
20 \\
32\end{array}\right.$ & $\begin{array}{l}60 \\
52 \\
32 \\
20 \\
61\end{array}$ \\
\hline 50.0 & 50 & 33.3 & $\left\{\begin{array}{r}1 \\
2 \\
4 \\
11 \\
41\end{array}\right.$ & $\begin{array}{l}40 \\
16 \\
32 \\
43 \\
53\end{array}$ \\
\hline 91.0 & 0 & $a_{9}$ & $\left\{\begin{array}{l}7 \cdot 5 \\
15 \\
20 \\
25\end{array}\right.$ & $\begin{array}{r}42.5 \\
24.2 \\
16.4 \\
9.8\end{array}$ \\
\hline
\end{tabular}

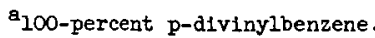

TABLE 48. - EFFECT OF IRRADIATION ON SOLUBILITY OF MIXTURES OF POLXTETRAMETHYIENE SERACATE AND STYRENE

[See flgure 42]

\begin{tabular}{|c|c|c|}
\hline $\begin{array}{l}\text { Styrene, } \\
\text { percent }\end{array}$ & $\begin{array}{l}\text { Dose, } \\
\text { megarep }\end{array}$ & $\begin{array}{l}\text { Welght } \\
\text { extracted, } \\
\text { percent }\end{array}$ \\
\hline 0 & $\begin{array}{r}4 \\
12 \\
30 \\
50 \\
60\end{array}$ & $\begin{array}{r}100 \\
79 \\
59 \\
44 \\
38\end{array}$ \\
\hline 1.0 & $\begin{array}{r}9 \\
24 \\
33\end{array}$ & $\begin{array}{l}80 \\
63 \\
56\end{array}$ \\
\hline 4.0 & $\begin{array}{l}4 \\
11 \\
22.5 \\
35 \\
45\end{array}$ & $\begin{array}{r}100 \\
84 \\
70 \\
58 \\
48\end{array}$ \\
\hline 10.0 & $\begin{array}{r}4 \\
15 \\
31 \\
50\end{array}$ & $\begin{array}{r}100 \\
84 \\
66 \\
54\end{array}$ \\
\hline
\end{tabular}


TABLE 49.- SWFHUTNG INDEX OF IRRADIATED

MIXTURESS OF POLYEITYIENE SUCCINAITE

AND DIVINYIBENZEKNE

[See figure 43]

\begin{tabular}{|c|c|c|c|}
\hline $\begin{array}{l}\text { Divinylbenzene } \\
\text { weight, } \\
\text { percent }\end{array}$ & $\begin{array}{c}\text { Dose, } \\
\text { megarep }\end{array}$ & $\begin{array}{l}\text { Welght } \\
\text { extracted, } \\
\text { percent }\end{array}$ & $\frac{w_{f}-w_{1}}{w_{1}}$ \\
\hline $\begin{array}{c}1.96 \\
.\end{array}$ & $\begin{array}{l}\left\{\begin{array}{r}10 \\
25 \\
50 \\
100 \\
200 \\
400\end{array}\right. \\
\left\{\begin{array}{r}2 \\
20 \\
50 \\
100 \\
200 \\
250 \\
300 \\
380 \\
400\end{array}\right. \\
\left\{\begin{array}{r}50 \\
60 \\
100 \\
200 \\
320 \\
380\end{array}\right. \\
\left\{\begin{array}{r}50 \\
100 \\
200 \\
300 \\
400\end{array}\right.\end{array}$ & $\begin{array}{r}100 \\
100 \\
100 \\
100 \\
100 \\
100 \\
100 \\
100 \\
100 \\
100 \\
87 \\
64 \\
58 \\
55 \\
55 \\
\\
74 \\
80 \\
58 \\
44 \\
40 \\
39 \\
55 \\
40 \\
35 \\
34 \\
32\end{array}$ & $\begin{array}{c}\text { Soluble } \\
\text { Soluble } \\
\text { Soluble } \\
\text { Soluble } \\
\text { Soluble } \\
\text { Soluble } \\
\text { Soluble } \\
\text { Soluble } \\
\text { Soluble } \\
\text { Soluble } \\
85.5 \\
10.7 \\
1.1 \\
1.0 \\
1.1 \\
\\
3.8 \\
2.6 \\
1.0 \\
1.10 \\
1.09 \\
1.0 \\
1.8 \\
1.0 \\
1.0 \\
1.9 \\
1.0\end{array}$ \\
\hline
\end{tabular}

$a_{w_{i}}$ is initial weight of unswollen polymer; $W_{f}$ is weight of swollen polymer.
TABLE 50.- SWEILIMG INDEX OF IRRADIATED

MIXTURES OF POLYTEITRAMETHYIFHE SEBACATE

\section{AND DIVINYBRETRZETE}

[See figure 44]

\begin{tabular}{|c|c|c|}
\hline $\begin{array}{c}\text { Divinylbenzene } \\
\text { weight, } \\
\text { percent }\end{array}$ & $\begin{array}{c}\text { Dose, } \\
\text { megarep }\end{array}$ & $\begin{array}{c}\frac{w_{f}-w_{1}}{w_{1}} \\
(a)\end{array}$ \\
\hline 0 & $\begin{array}{r}4 \\
12 \\
30 \\
60\end{array}$ & $\begin{array}{c}\text { Soluble } \\
43.3 \\
27.1 \\
16.5\end{array}$ \\
\hline .99 & $\begin{array}{r}4 \\
20 \\
36 \\
50\end{array}$ & $\begin{array}{l}33 \\
24 \\
16 \\
14\end{array}$ \\
\hline 3.70 & $\begin{array}{l}4 \\
8.5 \\
25 \\
50\end{array}$ & $\begin{array}{r}23.7 \\
18.3 \\
10.1 \\
6.0\end{array}$ \\
\hline 9.09 & $\begin{array}{c}4 \\
7.3 \\
13 \\
32 \\
55\end{array}$ & $\begin{array}{l}2.3 \\
2.2 \\
2.3 \\
2.2 \\
2.2\end{array}$ \\
\hline 33.3 & $\begin{array}{r}4 \\
11 \\
40 \\
55\end{array}$ & $\begin{array}{l}.96 \\
1.02 \\
1.02 \\
1.01\end{array}$ \\
\hline
\end{tabular}

$a_{1}$ is Intitial weight of unswollen polymer; $W_{f}$ is weight of swolien polymer. 


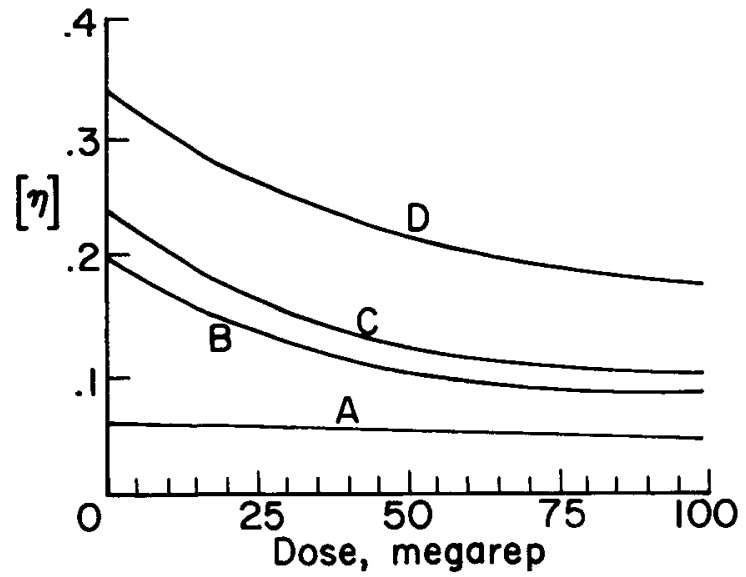

Figure 1.- Effect of irradiation on intrinsic viscosity of polyethylene succinate $\left[\left(\mathrm{CH}_{2}\right)_{2}-\mathrm{OCO}-\left(\mathrm{CH}_{2}\right) 2^{-\mathrm{OCO}_{n}}\right.$. See table 4.

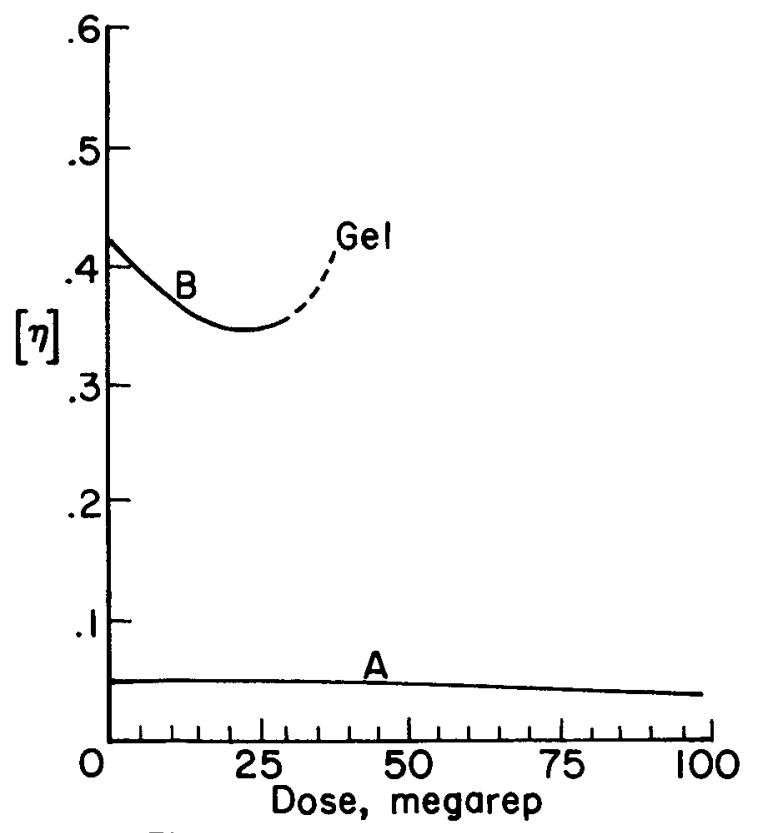

Figure 3.- Effect of irradiation on intrinsic viscosity of polyethylene azelate $\left[\left(\mathrm{CH}_{2}\right)_{2}-\mathrm{OCO}-\left(\mathrm{CH}_{2}\right) 7^{-\mathrm{OCO}}\right]_{\mathrm{n}}$. see table 6 .

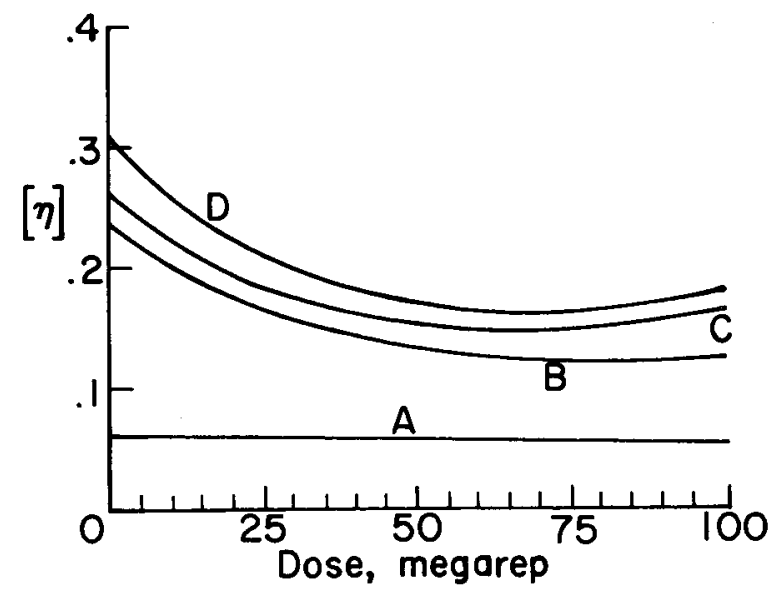

Figure 2.- Effect of irradiation on intrinsic viscosity of polyethylene adipate $\mathrm{f}\left(\mathrm{CH}_{2}\right)_{2}-\mathrm{OCO}-\left(\mathrm{CH}_{2}\right)_{4}-\mathrm{OCO}_{\mathrm{n}}$.
See table 5 .

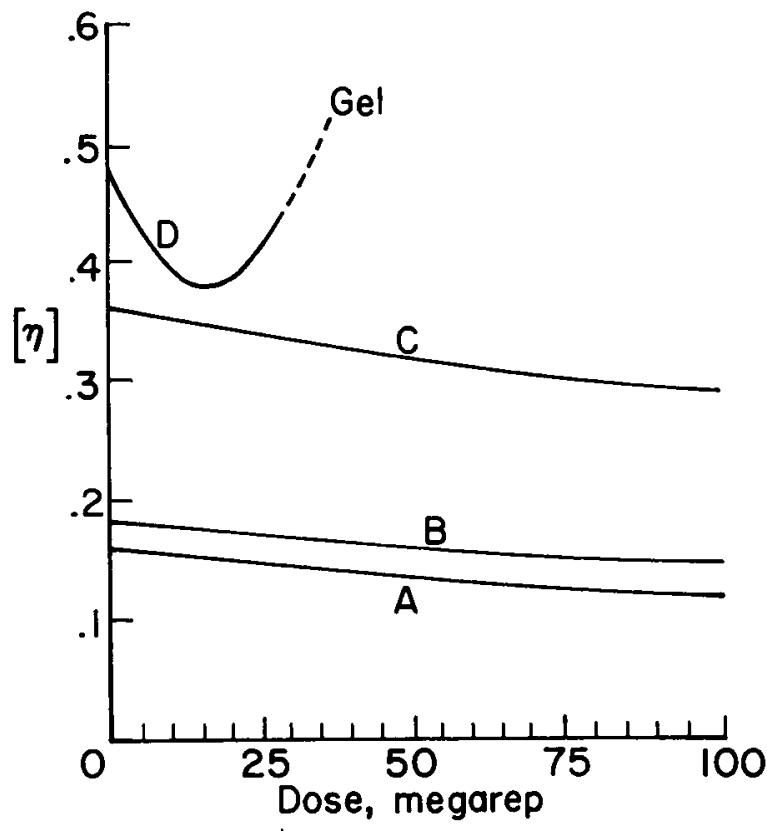

Figure 4.- Effect of irradiation on intrinsic viscosity of polyethylene sebacate

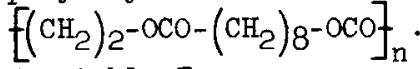
see table 7 . 


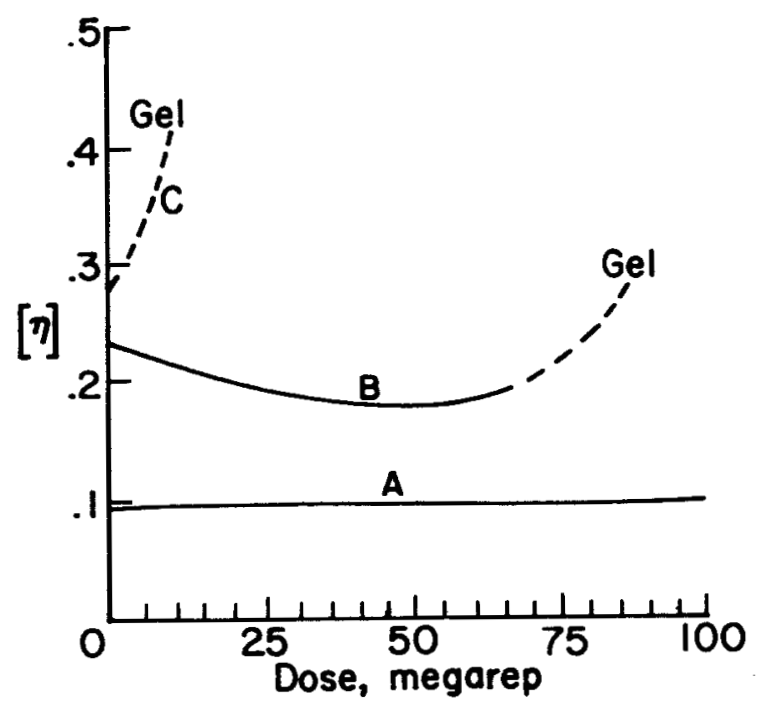

Figure 5.- Effect of irradiation on intrinsic viscosity of polytrimethylene succinate $\left[\left(\mathrm{CH}_{2}\right)_{3}-\mathrm{OCO}-\left(\mathrm{CH}_{2}\right)_{2}-\mathrm{OCO}_{\mathrm{n}}\right.$. see table 8 .

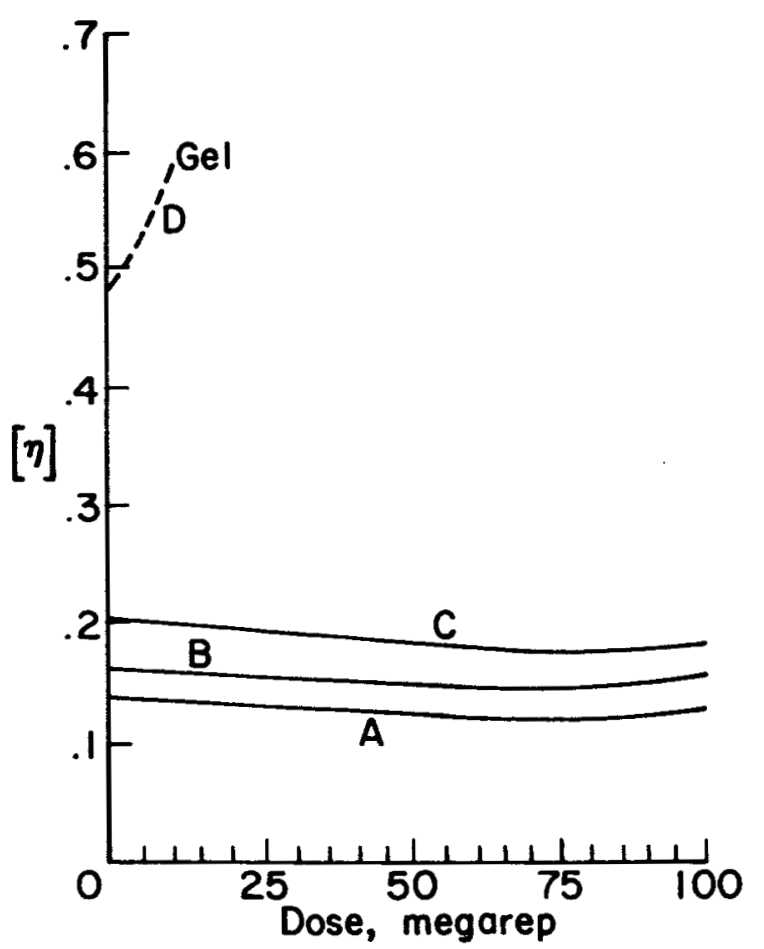

Figure 7.- Effect of irradiation on intrinsic viscosity of polytrimethylene sebacate $\left[\left(\mathrm{CH}_{2}\right)_{3}-\mathrm{OCO}-\left(\mathrm{CH}_{2}\right) 8-\mathrm{OCO}\right]_{\mathrm{n}}$.

See table 10.

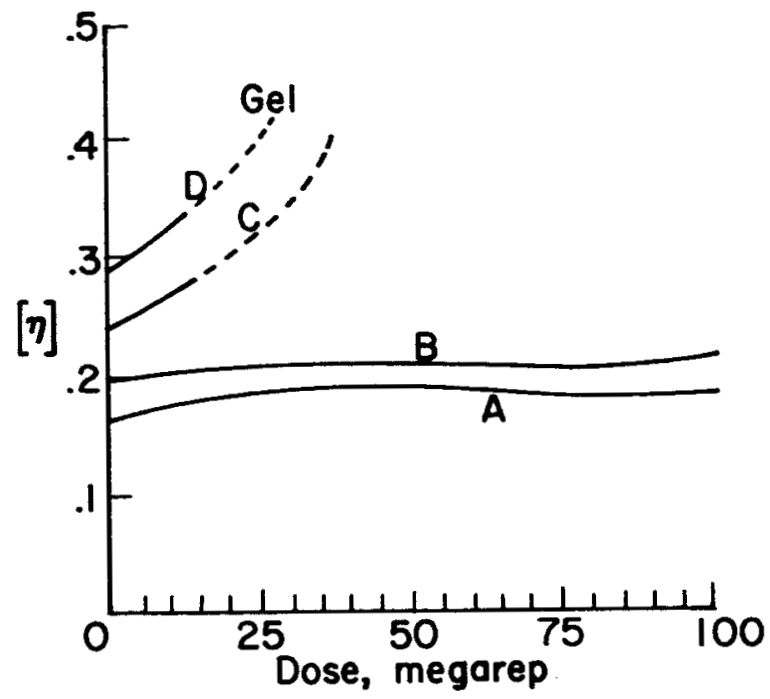

Figure 6.- Effect of irradiation on intrinsic viscosity of polytrimethylene adipate $\left[\left(\mathrm{CH}_{2}\right)_{3}-\mathrm{OCO}-\left(\mathrm{CH}_{2}\right) 4-\mathrm{OCO}_{\mathrm{n}}\right.$. See table 9 .

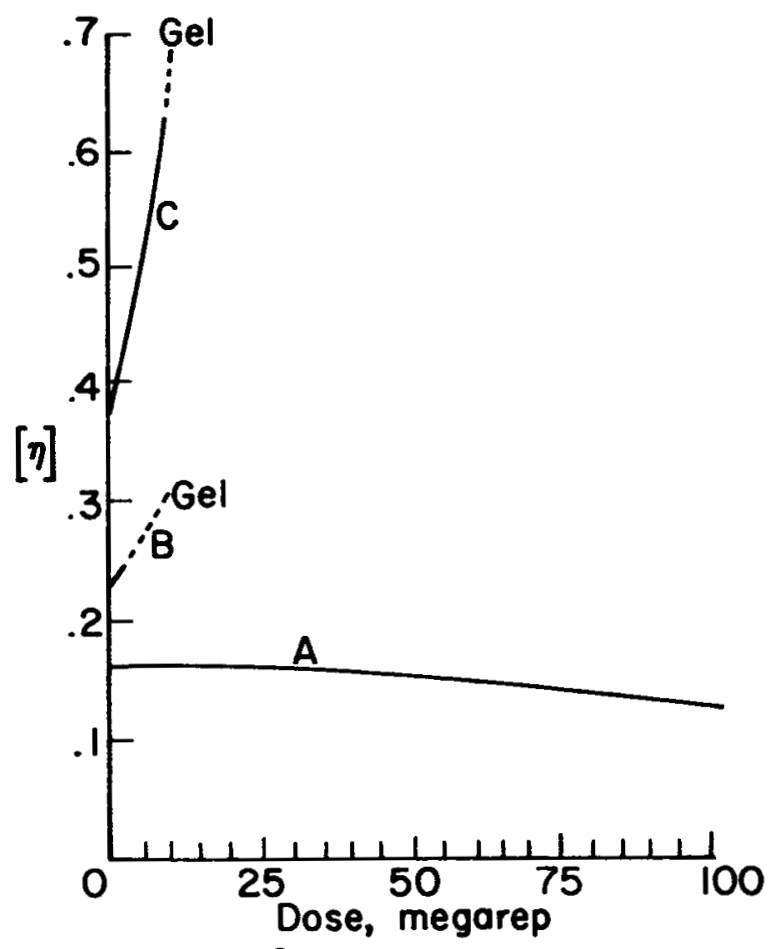

Figure 8. - Effect of irradiation on intrinsic viscosity of polytetramethylene succinate $\left[\left(\mathrm{CH}_{2}\right)_{4}-\mathrm{OCO}-\left(\mathrm{CH}_{2}\right) 2^{-O \mathrm{OO}}\right]_{\mathrm{n}}$. see table 11 . 


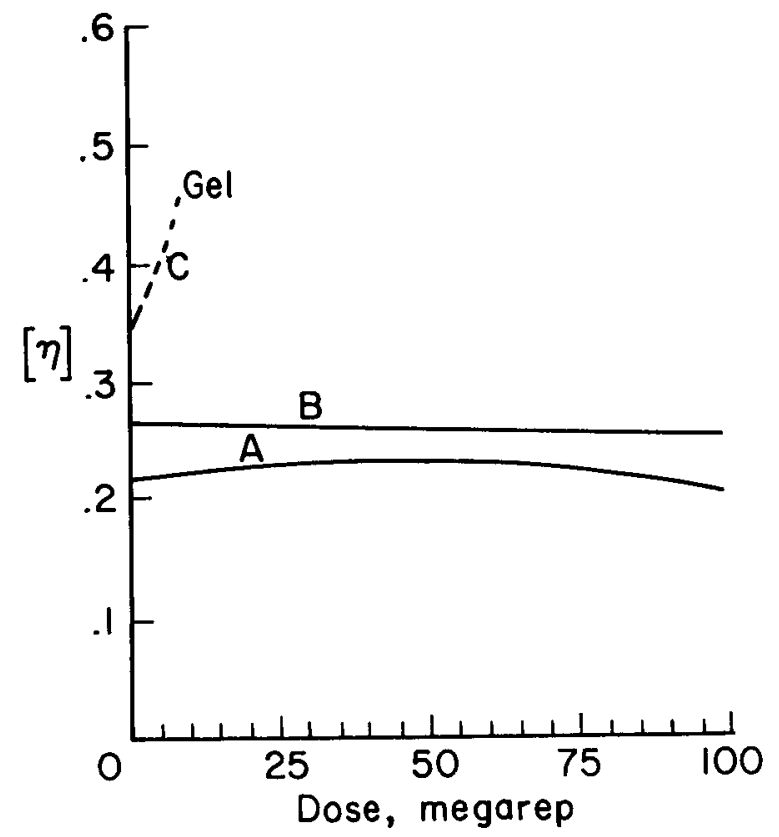

Figure 9.- Effect of irradiation on intrinsic viscosity of polytetramethylene adipate $\left[\left(\mathrm{CH}_{2}\right)_{4}-\mathrm{OCO}-\left(\mathrm{CH}_{2}\right)_{4}-\mathrm{OCO}_{\mathrm{n}}\right.$. see table 12 .

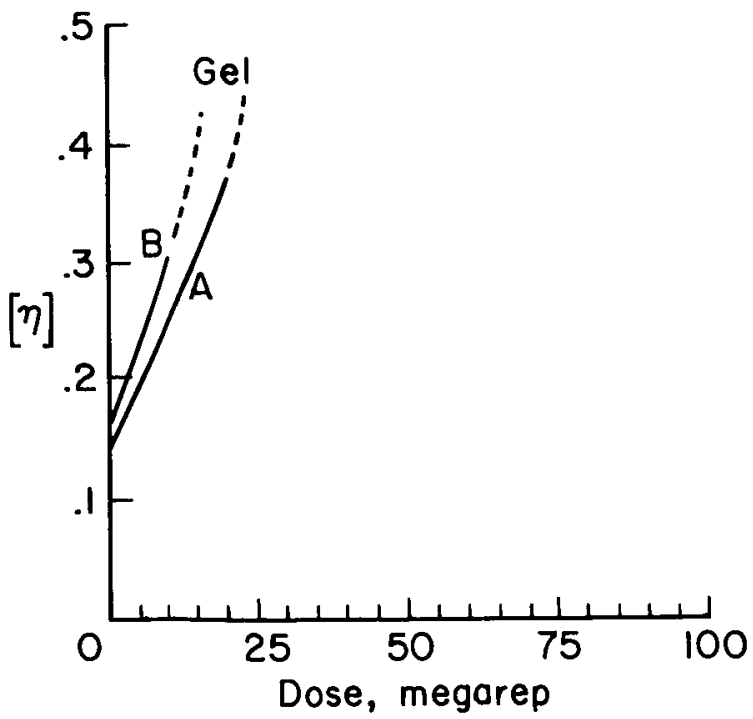

Figure 11.- Effect of irradiation on intrinsic viscosity of polypentamethylene succinate

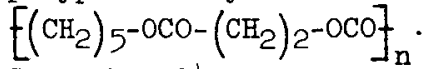
See table 14.

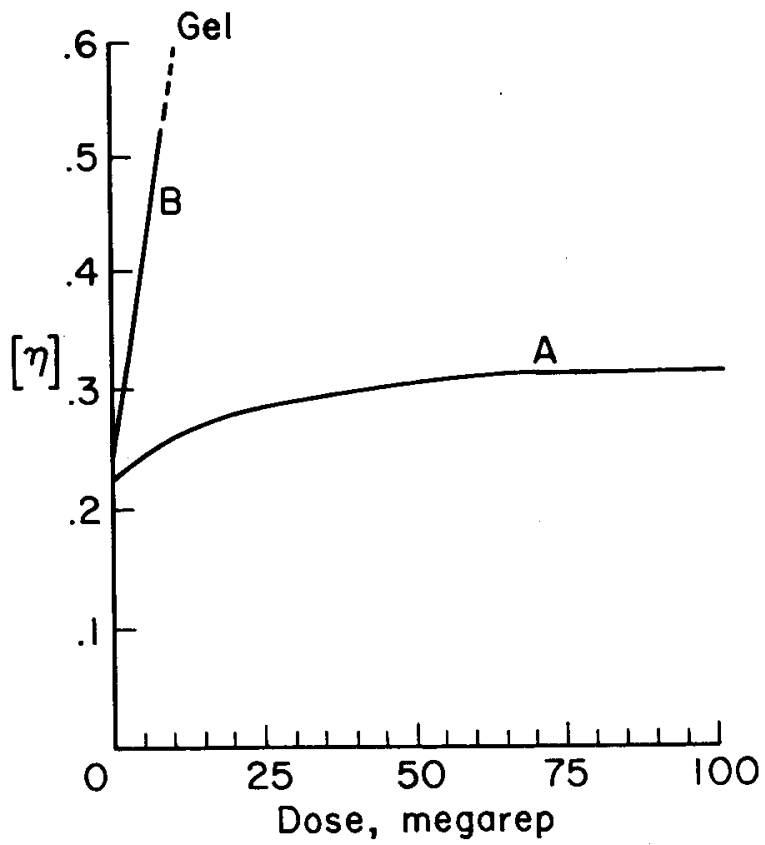

Figure 10.- Effect of irradiation on intrinsic viscosity of polytetramethylene sebacate $\left[\left(\mathrm{CH}_{2}\right)_{4}-\mathrm{OCO}-\left(\mathrm{CH}_{2}\right) 8-\mathrm{OCO}_{\mathrm{n}}\right.$. See table 13 .

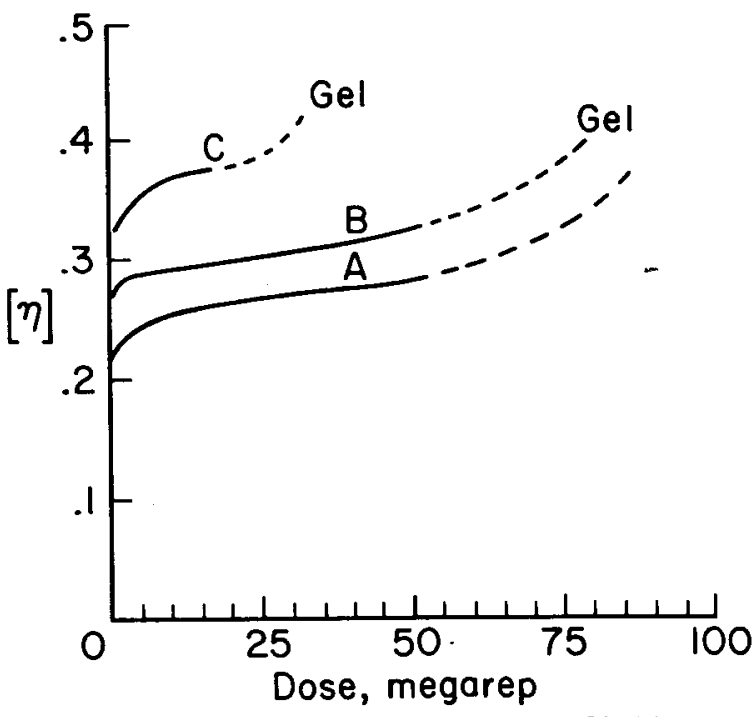

Figure 12.- Effect of irradiation on intrinsic viscosity of polypentamethylene adipate $\left[\left(\mathrm{CH}_{2}\right)_{5}-\mathrm{OCO}-\left(\mathrm{CH}_{2}\right)_{4}-\mathrm{OCO}\right]_{\mathrm{n}}$. See table 15. 


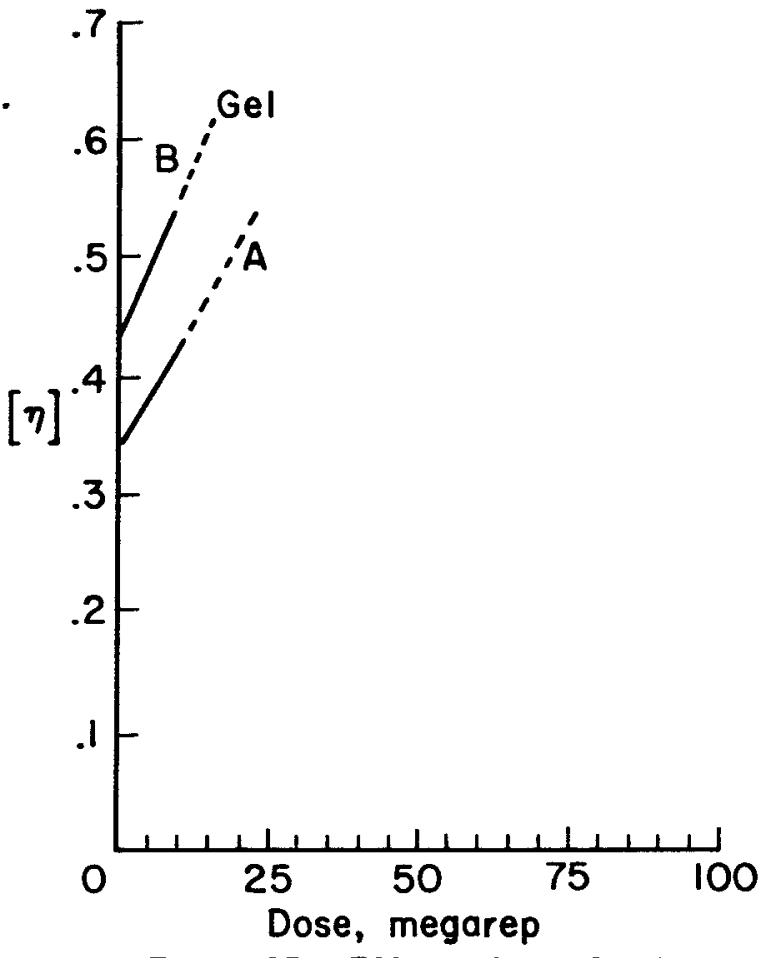

Figure 13.- Effect of irradiation on intrinsic viscosity of polypentamethylene azelate $\left[\left(\mathrm{CH}_{2}\right)_{5}-\mathrm{OCO}-\left(\mathrm{CH}_{2}\right)_{7}-\mathrm{OCO}\right]_{\mathrm{n}}$. See table 16.

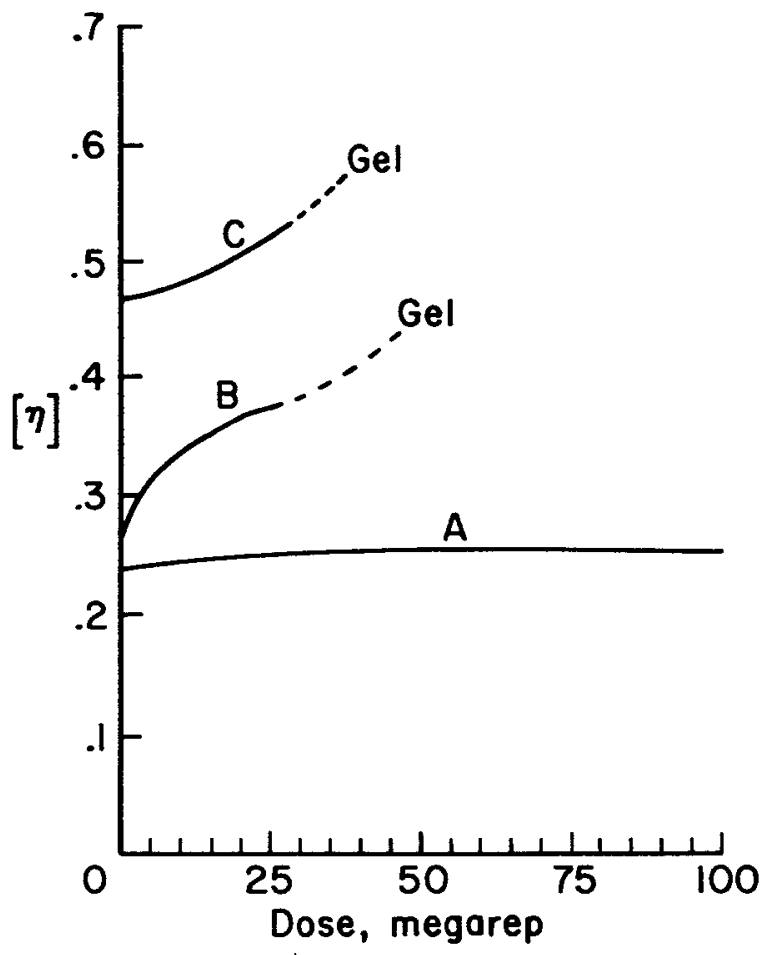

Figure 14.- Effect of irradiation on intrinsic viscosity of polypentamethylene sebacate $\left[\left(\mathrm{CH}_{2}\right)_{5}-\mathrm{OCO}-\left(\mathrm{CH}_{2}\right) 8-\mathrm{OCO}_{\mathrm{n}}\right.$. See table 17 .

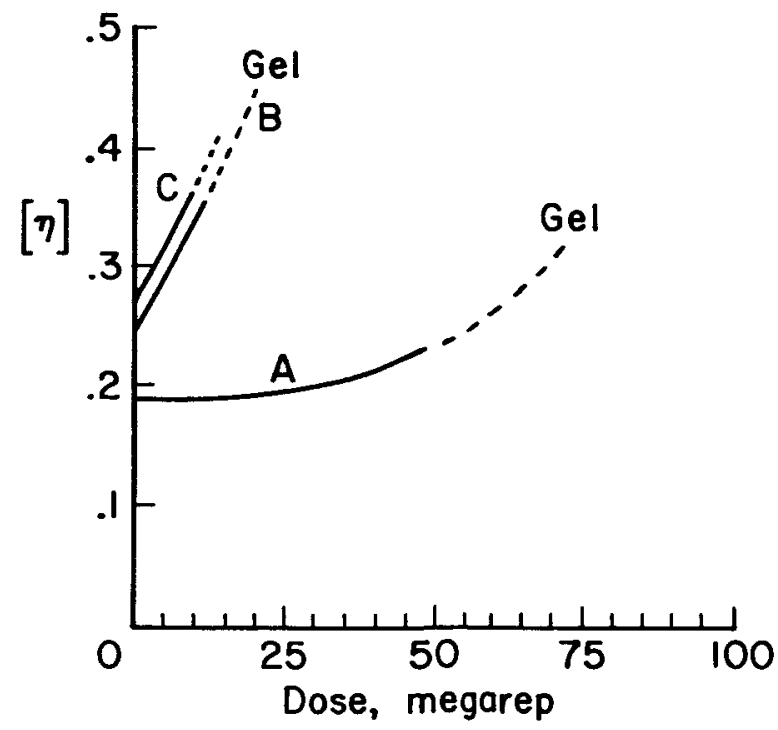

Figure 15.- Effect of irradiation

on intrinsic viscosity of

polydecamethylene sebacate

$\left[\left(\mathrm{CH}_{2}\right)_{10}-\mathrm{OCO}-\left(\mathrm{CH}_{2}\right) 8^{-O C O}\right]_{n}$.

see table 18. 


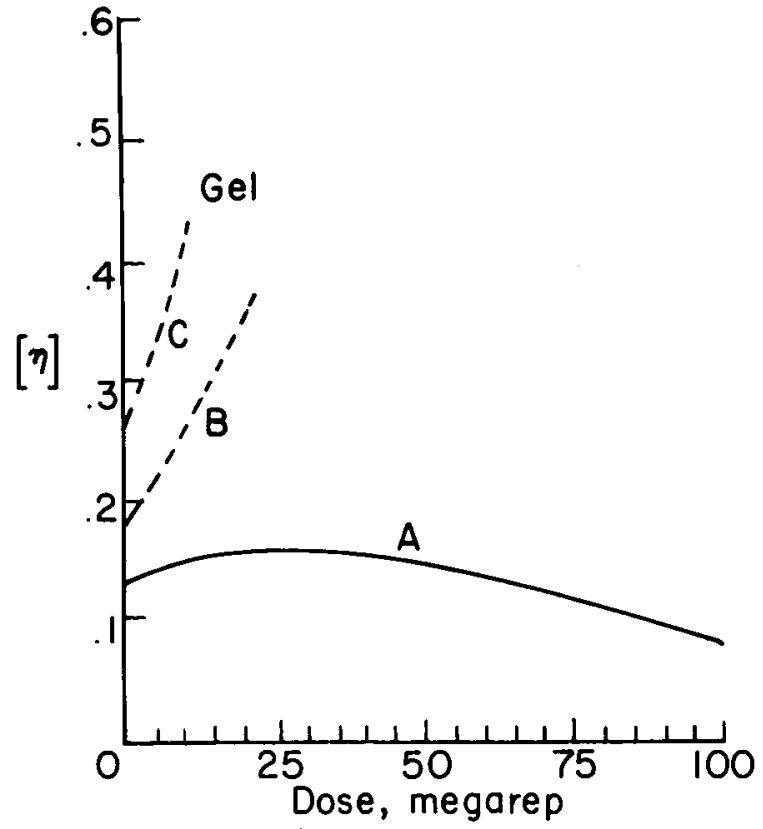

Figure 16.- Effect of irradiation on intrinsic viscosity of poly-l-methylethylene succinate $\left[\mathrm{CH}_{2}-\mathrm{CH}\left(\mathrm{CH}_{3}\right)-\mathrm{OCO}-\left(\mathrm{CH}_{2}\right) 2^{-O C O}\right]_{\mathrm{n}}$. See table 19.

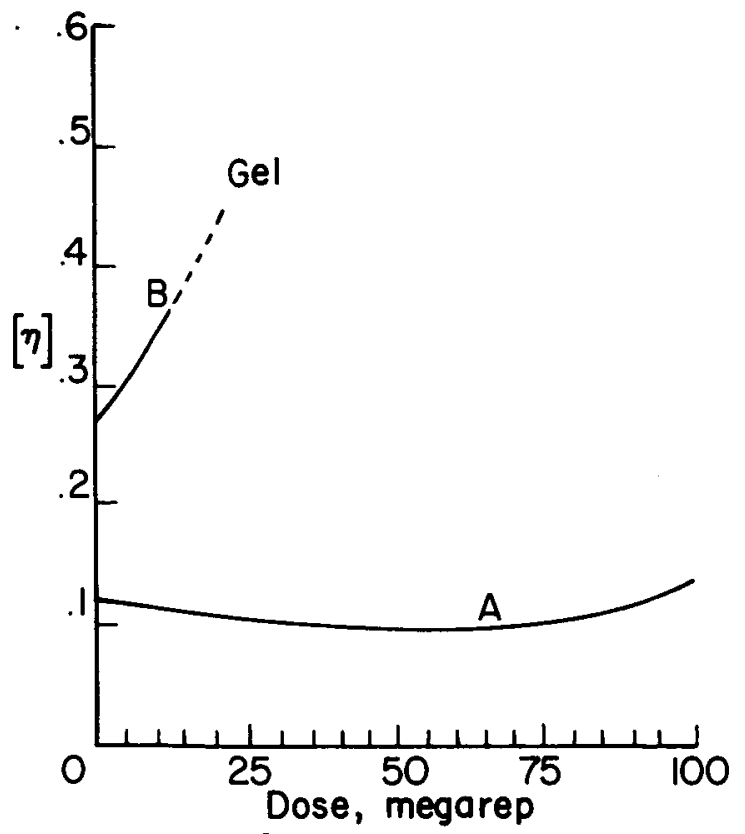

Figure 18.- Effect of irradiation on intrinsic viscosity of poly-1-methylethylene azelate $\left[\mathrm{CH}_{2}-\mathrm{CH}\left(\mathrm{CH}_{3}\right)-\mathrm{OCO}-\left(\mathrm{CH}_{2}\right) 7^{-O C O}\right]_{\mathrm{n}}$. See table 21 .

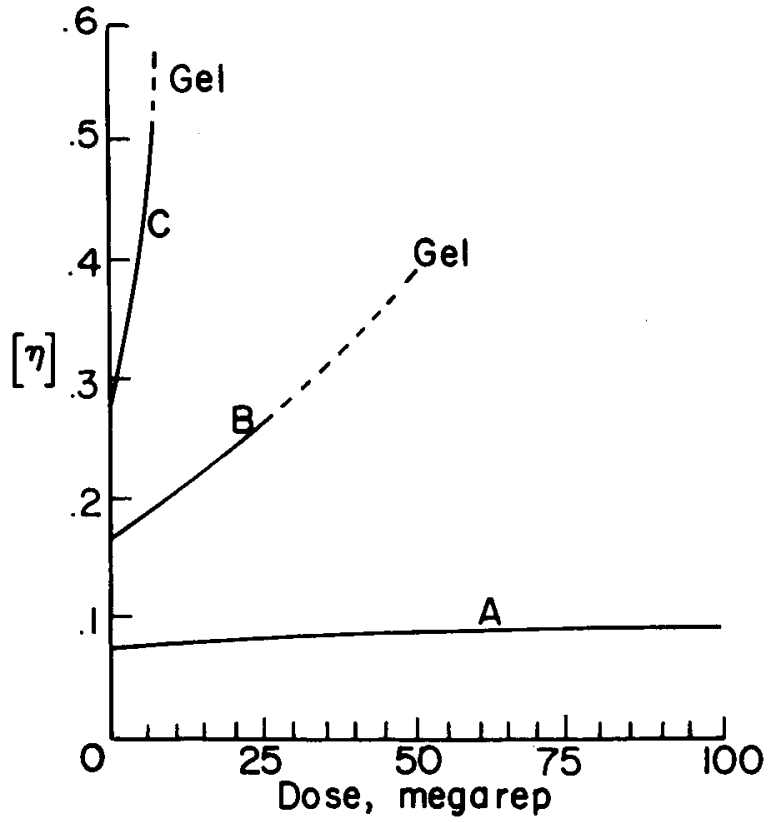

Figure 17.- Effect of irradiation on intrinsic viscosity of poly-1-methylethylene adipate $\left[\mathrm{CH}_{2}-\mathrm{CH}\left(\mathrm{CH}_{3}\right)-\mathrm{OCO}-\left(\mathrm{CH}_{2}\right)_{4}-\mathrm{OCO}_{\mathrm{n}}\right.$. see table 20 .

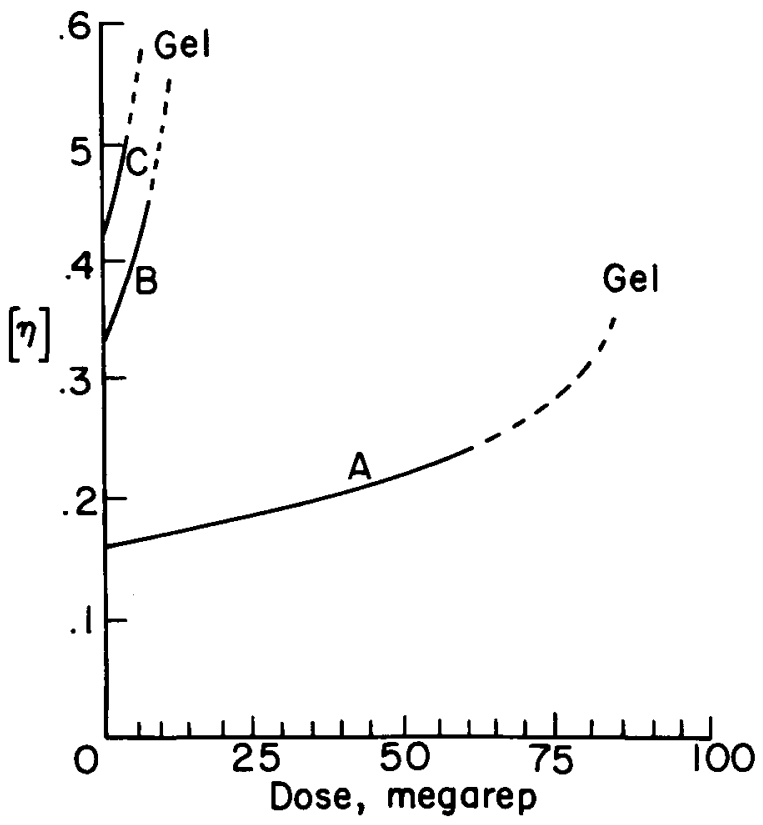

Figure 19.- Effect of irradiation on intrinsic viscosity of poly-l-methylethylene sebacate $\left[\mathrm{CH}_{2}-\mathrm{CH}\left(\mathrm{CH}_{3}\right)-\mathrm{OCO}-\left(\mathrm{CH}_{2}\right) 8-\mathrm{OCO}_{\mathrm{n}}\right.$. See table 22 . 


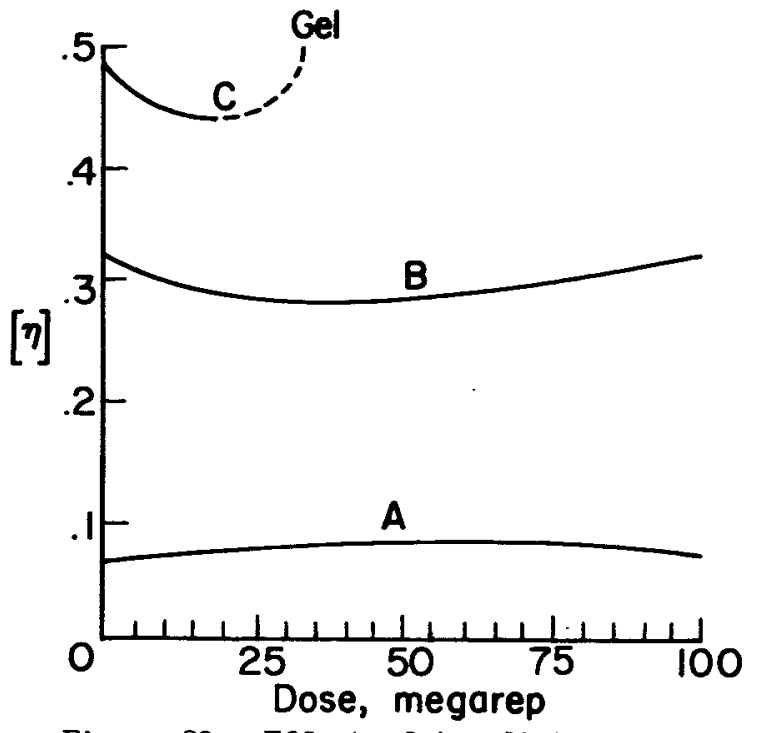

Figure 20.- Effect of irradiation on intrinsic viscosity of poly-2,2-dimethyltrimethylene succinate $\left[\mathrm{CH}_{2}-\mathrm{C}\left(\mathrm{CH}_{3}\right)_{2}-\mathrm{CH}_{2}-\mathrm{OCO}-\left(\mathrm{CH}_{2}\right)_{2}-\mathrm{OCO}_{\mathrm{n}}\right.$. see table 23 .

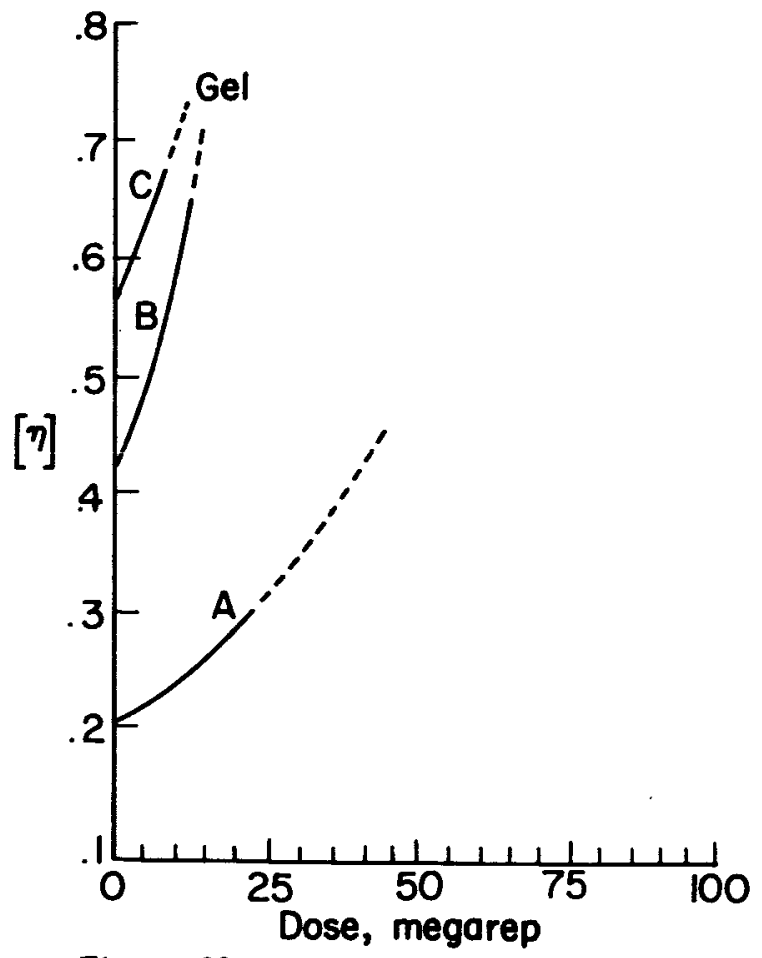

Figure 22. - Effect of irradiation

on intrinsic viscosity of

poly-2,2-dimethyltrimethylene azelate $\left[\mathrm{CH}_{2}-\mathrm{C}\left(\mathrm{CH}_{3}\right)_{2}-\mathrm{CH}_{2}-\mathrm{OCO}-\left(\mathrm{CH}_{2}\right)_{7}-\mathrm{OCO}\right]_{n}$. See table 25.

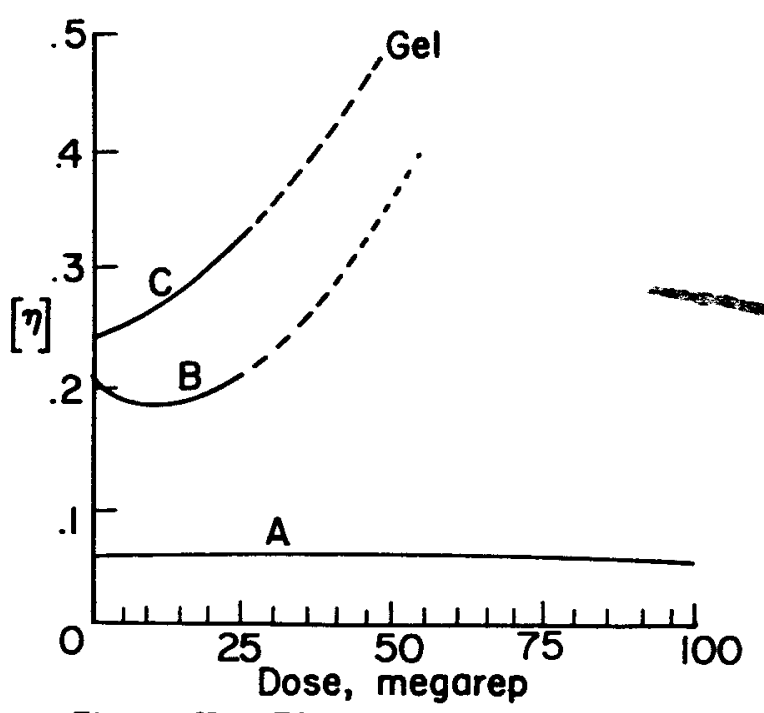

Figure 2l.- Effect of irradiation

on intrinsic viscosity of poly-2,2-dimethyltrimethylene adipate $\mathrm{fCH}_{2}-\mathrm{C}\left(\mathrm{CH}_{3}\right)_{2}-\mathrm{CH}_{2}-\mathrm{OCO}-\left(\mathrm{CH}_{2}\right)_{4}-\mathrm{OCO}_{n}$. see table 24.

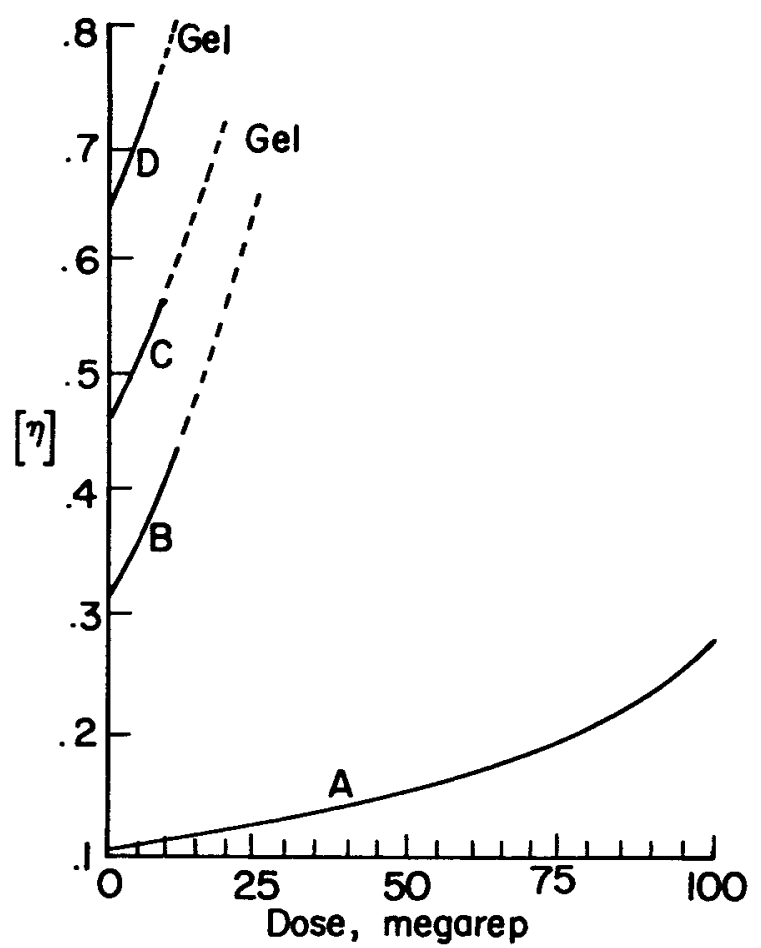

Figure 23.- Effect of irradiation on intrinsic viscosity of pol-y-2,2-dimethyltrimethylene sebacate $\mathrm{FCH}_{2}-\mathrm{C}\left(\mathrm{CH}_{3}\right)_{2}-\mathrm{CH}_{2}-\mathrm{OCO}-\left(\mathrm{CH}_{2}\right) 8-\mathrm{OCO}_{\mathrm{n}} \cdot$ see table 26 . 


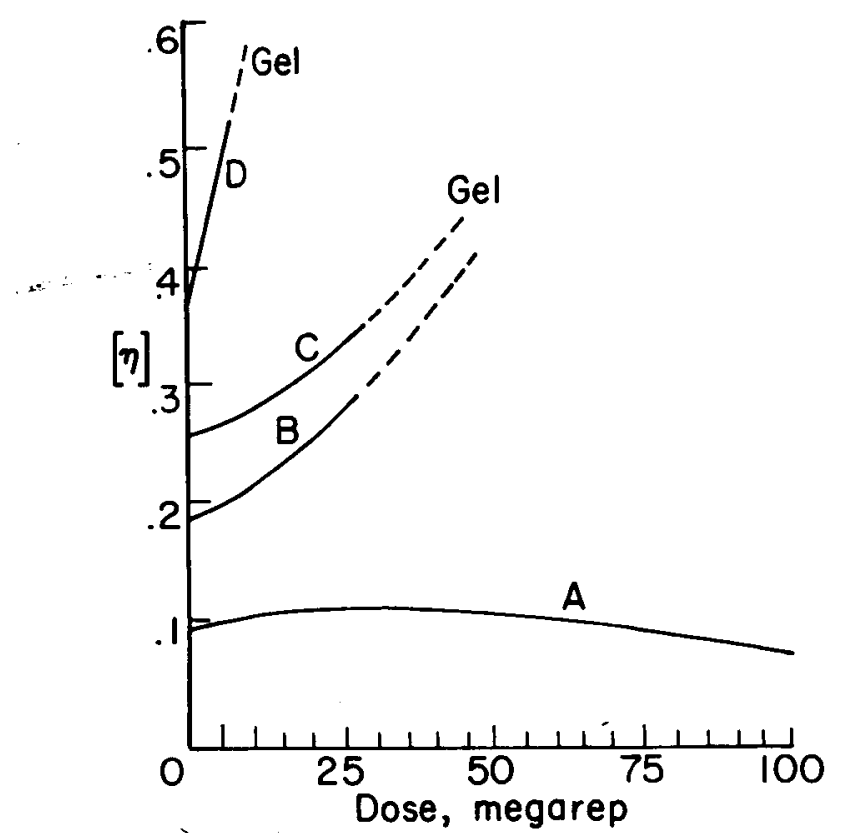

Figure 24.- Effect of irradiation

on intrinsic viscosity of

poly-2,2-diethyltrimethylene succinate $\left[\mathrm{CH}_{2}-\mathrm{C}\left(\mathrm{C}_{2} \mathrm{H}_{5}\right)_{2}-\mathrm{CH}_{2}-\mathrm{OCO}-\left(\mathrm{CH}_{2}\right)_{2}-\mathrm{OCO}_{\mathrm{n}}\right.$.

See table 27 .

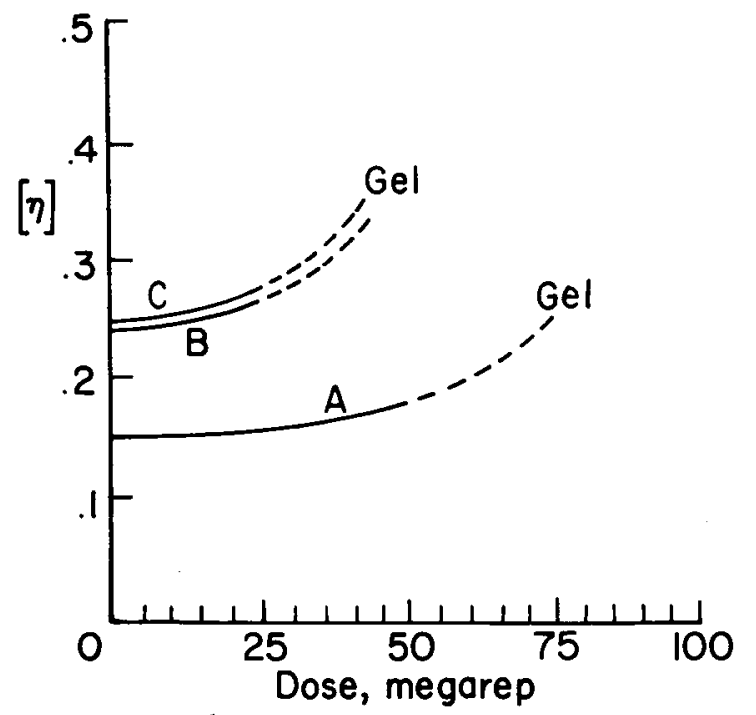

Figure 26.- Effect of irradiation on intrinsic viscosity of poly-2,2-diethyltrimethylene azelate $\left[\mathrm{CH}_{2}-\mathrm{C}\left(\mathrm{C}_{2} \mathrm{H}_{5}\right)_{2}-\mathrm{CH}_{2}-\mathrm{OCO}-\left(\mathrm{CH}_{2}\right)_{7}-\mathrm{OCO}_{\mathrm{n}}\right.$. See table 29.

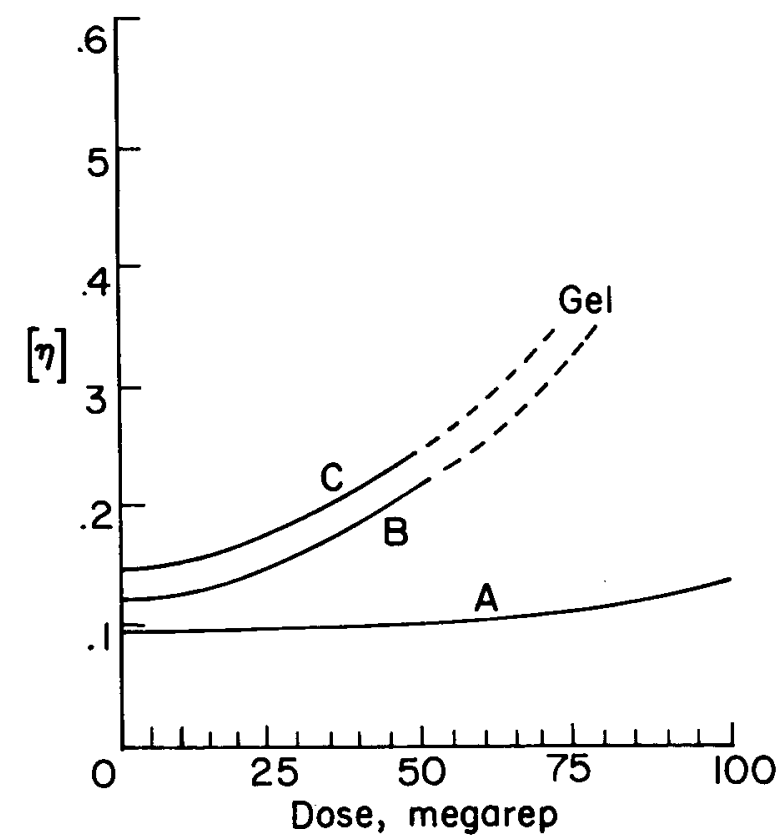

Figure 25.- Effect of irradiation on intrinsic viscosity of poly-2,2-diethyltrimethylene adipate $\left[\mathrm{CH}_{2}-\mathrm{C}\left(\mathrm{C}_{2} \mathrm{H}_{5}\right)_{2}-\mathrm{CH}_{2}-\mathrm{OCO}-\left(\mathrm{CH}_{2}\right)_{4}-\mathrm{OCO}_{\mathrm{n}}\right.$. See table 28.

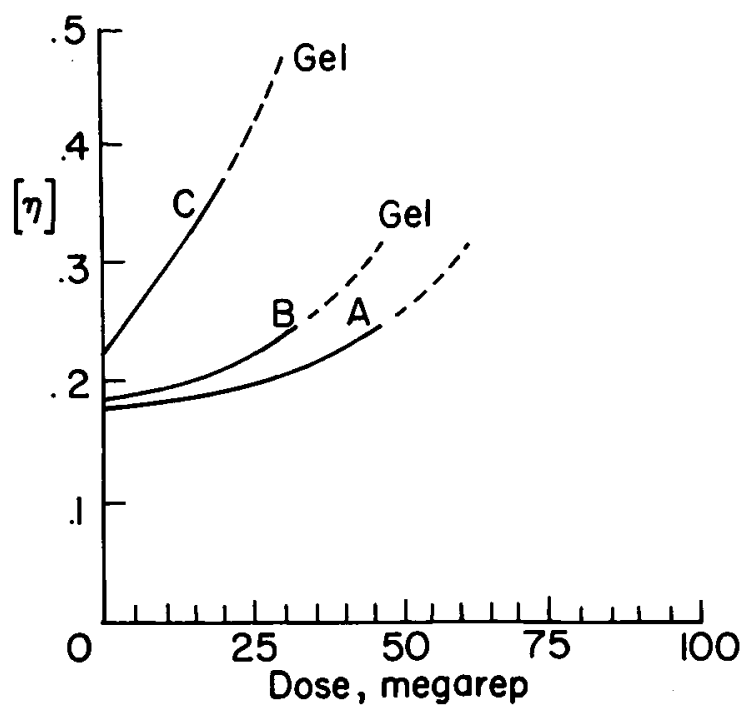

Figure 27.- Effect of irradiation on intrinsic viscosity of poly-2,2-diethyltrimethylene sebacate $\left[\mathrm{CH}_{2}-\mathrm{C}\left(\mathrm{C}_{2} \mathrm{H}_{5}\right)_{2}-\mathrm{CH}_{2}-\mathrm{OCO}-\left(\mathrm{CH}_{2}\right) 8^{-O C O}\right]_{\mathrm{n}}$. see table 30 . 


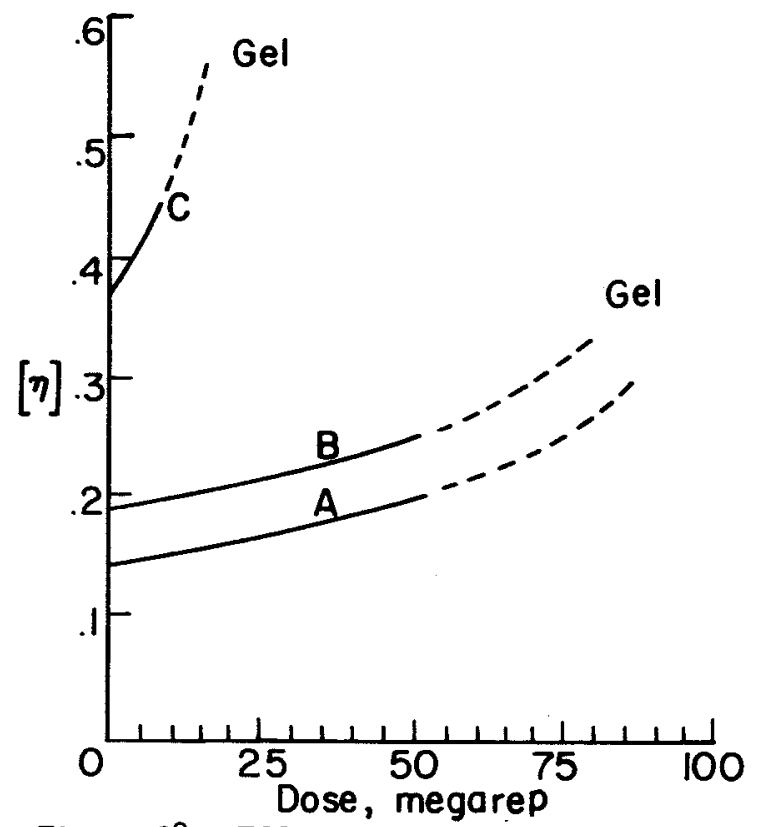

Figure 28.- Effect of irradiation

on intrinsic viscosity of

poly-3-methylpentamethylene succinate $\left[\left(\mathrm{CH}_{2}\right)_{2}-\mathrm{CH}\left(\mathrm{CH}_{3}\right)-\left(\mathrm{CH}_{2}\right)_{2}-\mathrm{OCO}-\left(\mathrm{CH}_{2}\right)_{2}-\mathrm{OCO}_{\mathrm{n}}\right.$. See table 31 .

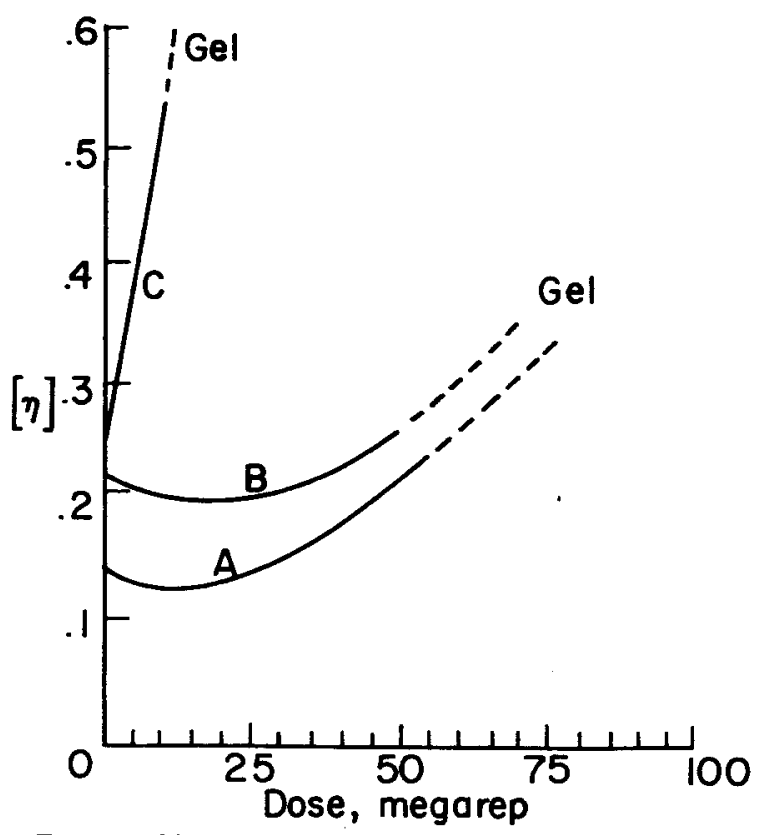

Figure 29.- Effect of irradiation

on intrinsic viscosity of

poly-3-methylpentamethylene adipate

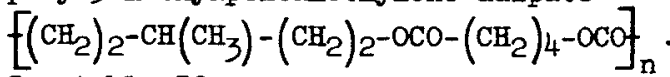
see table 32.

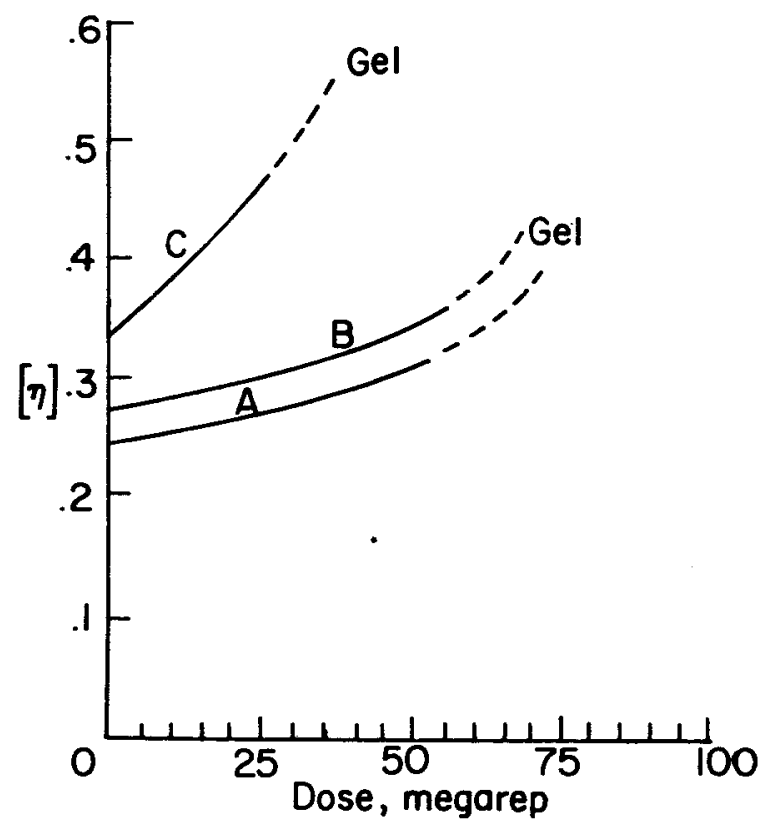

Figure 31.- Effect of irradiation on intrinsic viscosity of poly-3-methylpentamethylene sebacate $\left[\left(\mathrm{CH}_{2}\right)_{2}-\mathrm{CH}\left(\mathrm{CH}_{3}\right)-\left(\mathrm{CH}_{2}\right) 2^{-\mathrm{OCO}-}\left(\mathrm{CH}_{2}\right) 8^{-\mathrm{OCO}}\right]_{n}$. see table 34. 


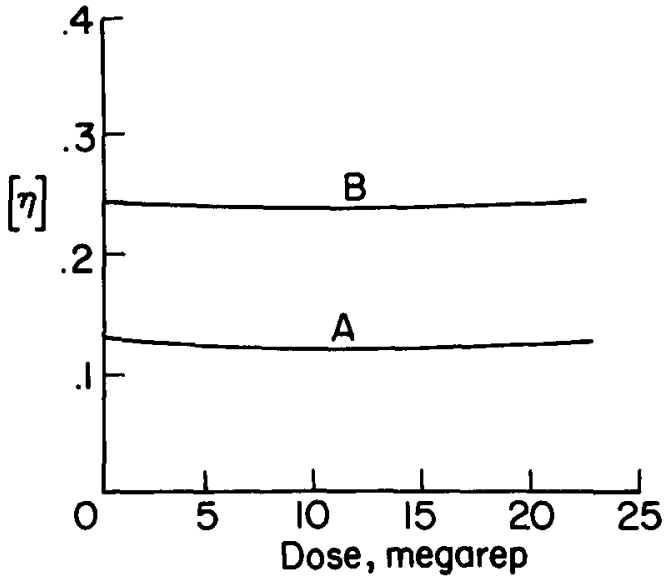

Figure 32.- Effect of Irradiation on intrinsic viscosity of polypentamethylene-2,3-aiphenyl succinate

$$
\begin{gathered}
{\left[\left(\mathrm{CH}_{2}\right)_{5}-\mathrm{OCO}-\mathrm{CH}\left(\mathrm{C}_{6} \mathrm{H}_{5}\right)-\mathrm{CH}\left(\mathrm{C}_{6} \mathrm{H}_{5}\right)-\mathrm{OCO}_{\mathrm{n}}\right.} \\
\text { See table } 35 .
\end{gathered}
$$

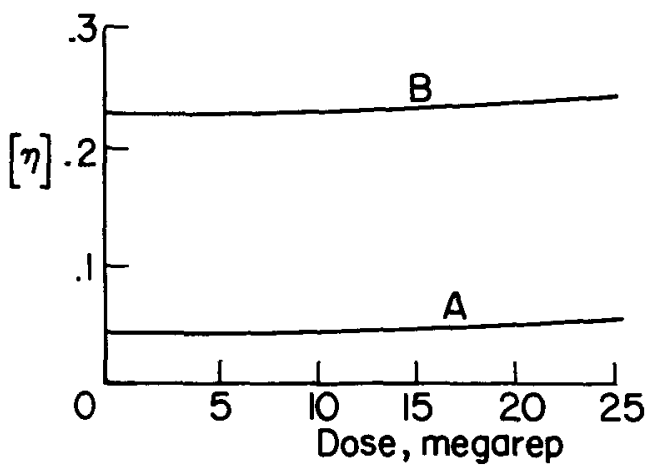

Figure 34.- Effect of irradiation on intrinsic viscosity of

poly-2,2-dimethyltrimethylene-3,3-dimethyl glutarate

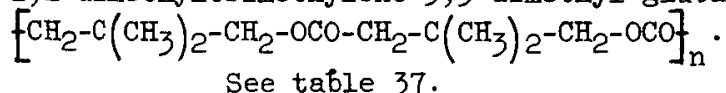

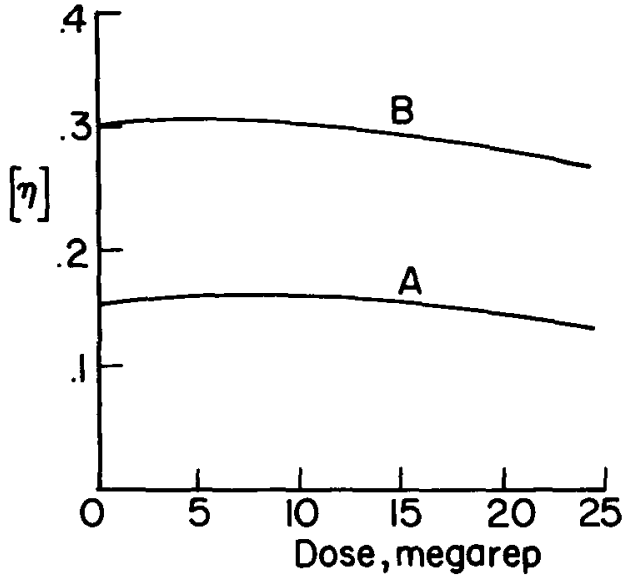

Figure 33.- Effect of irradiation on intrinsic viscosity of poly-3-methylpentamethylene-3-methyl adipate $\left[\left(\mathrm{CH}_{2}\right) 2^{-\mathrm{CH}}\left(\mathrm{CH}_{3}\right)-\left(\mathrm{CH}_{2}\right) 2^{-\mathrm{OCO}}-\left(\mathrm{CH}_{2}\right) 2^{-\mathrm{CH}}\left(\mathrm{CH}_{3}\right)-\mathrm{CH}_{2}-\mathrm{OCO}\right]_{n}$. see table 36 .

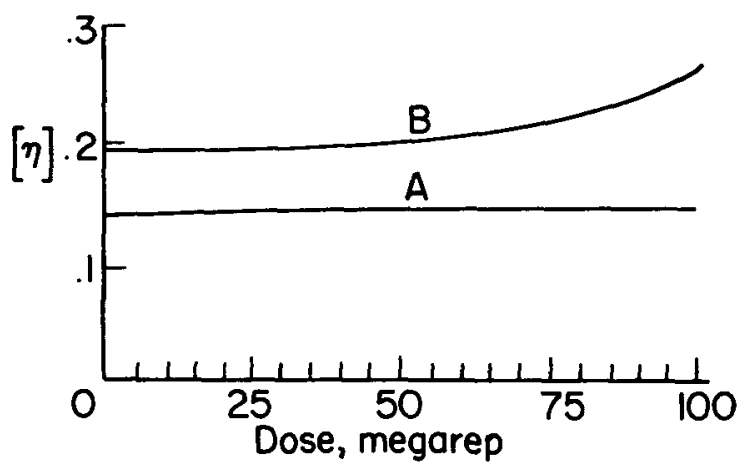

Figure 35.- Effect of irradiation on intrinsic viscosity of polypentamethylene-2-methyl succinate $\left[\left(\mathrm{CH}_{2}\right){ }_{5}-\mathrm{OCOCH}_{2} \mathrm{CH}\left(\mathrm{CH}_{3}\right) \mathrm{COO}\right]_{\mathrm{n}}$
See table 38. 


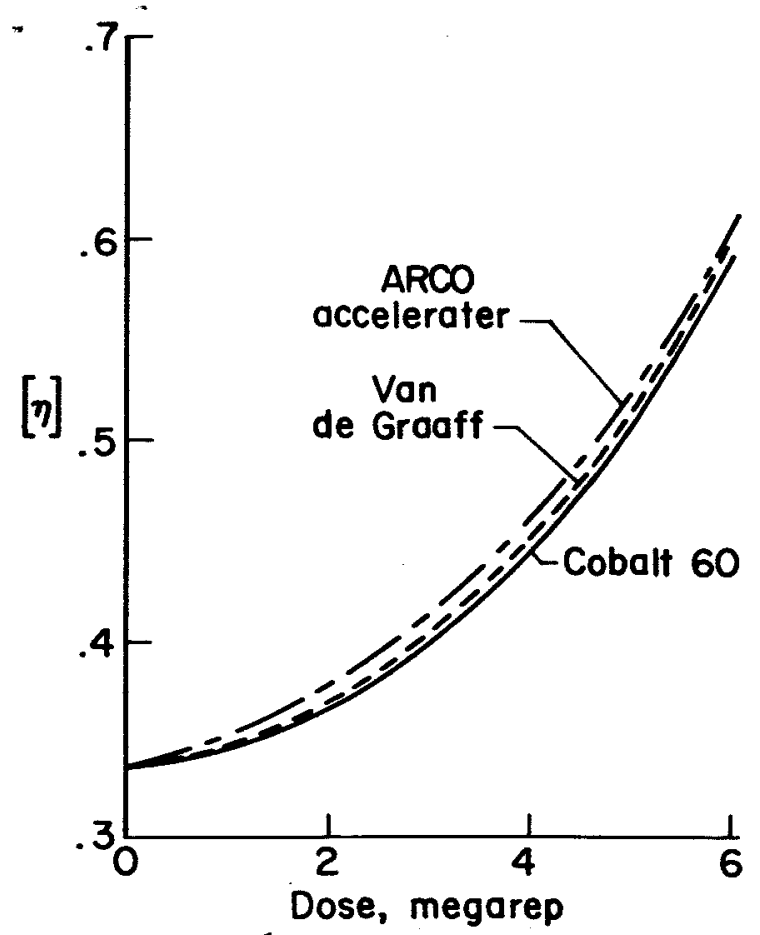

Figure 36.- Effect of dose rate and source on intrinsic viscosity of polytetramethylene sebacate (absence of oxygen at pressure of $1 \times 10^{-7} \mathrm{~mm} \mathrm{Hg}$ ). See table 39 .

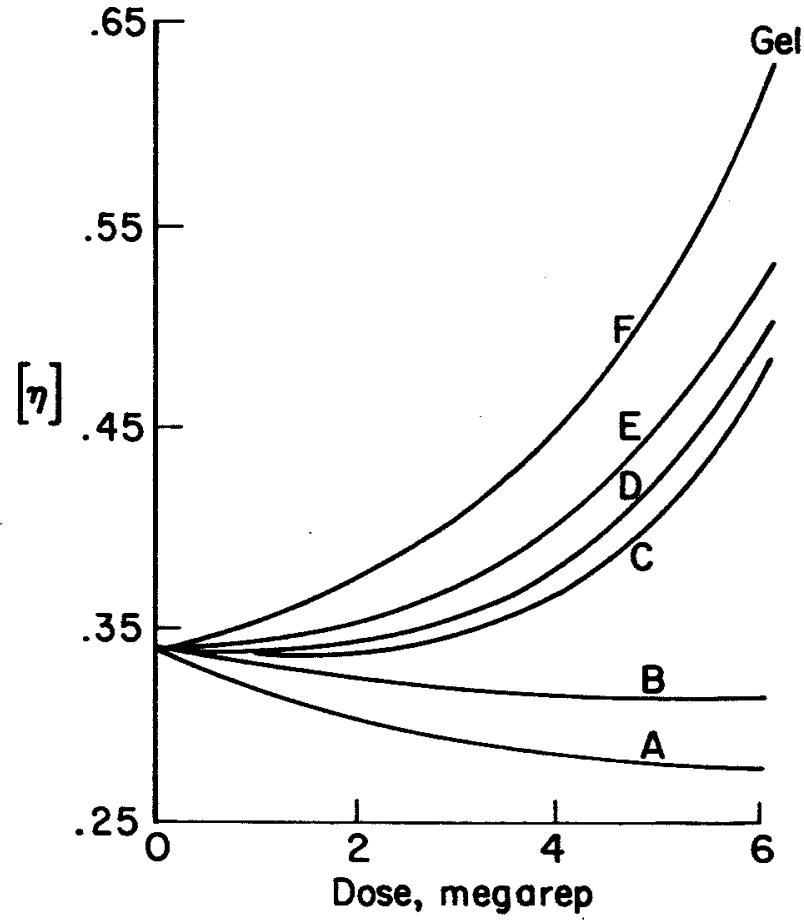

Figure 37.- Effect of air pressure and film thickness on intrinsic viscosity of polytetramethylene sebacate. See table 40.

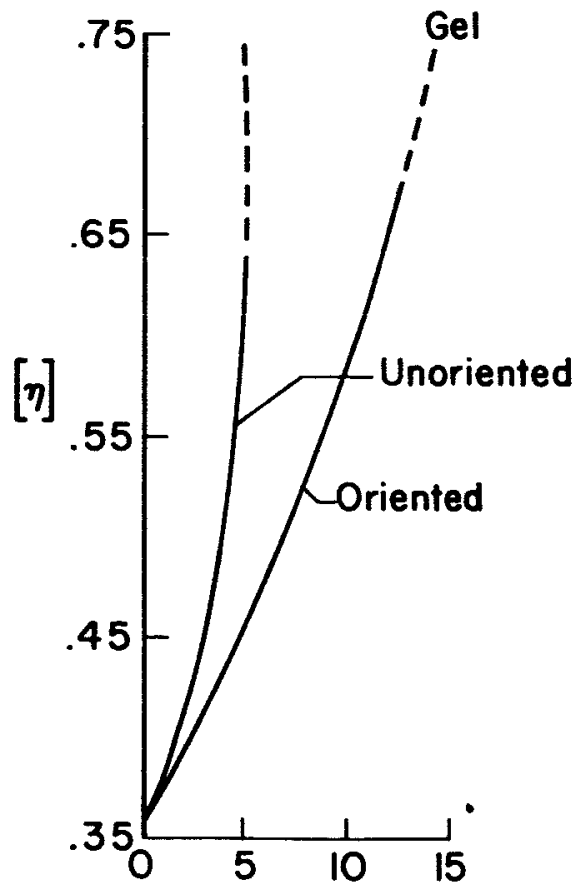

Dose, megarep

Figure 38. - Effect of orientation on intrinsic viscosity of polytetramethylene sebacate. See table 41.

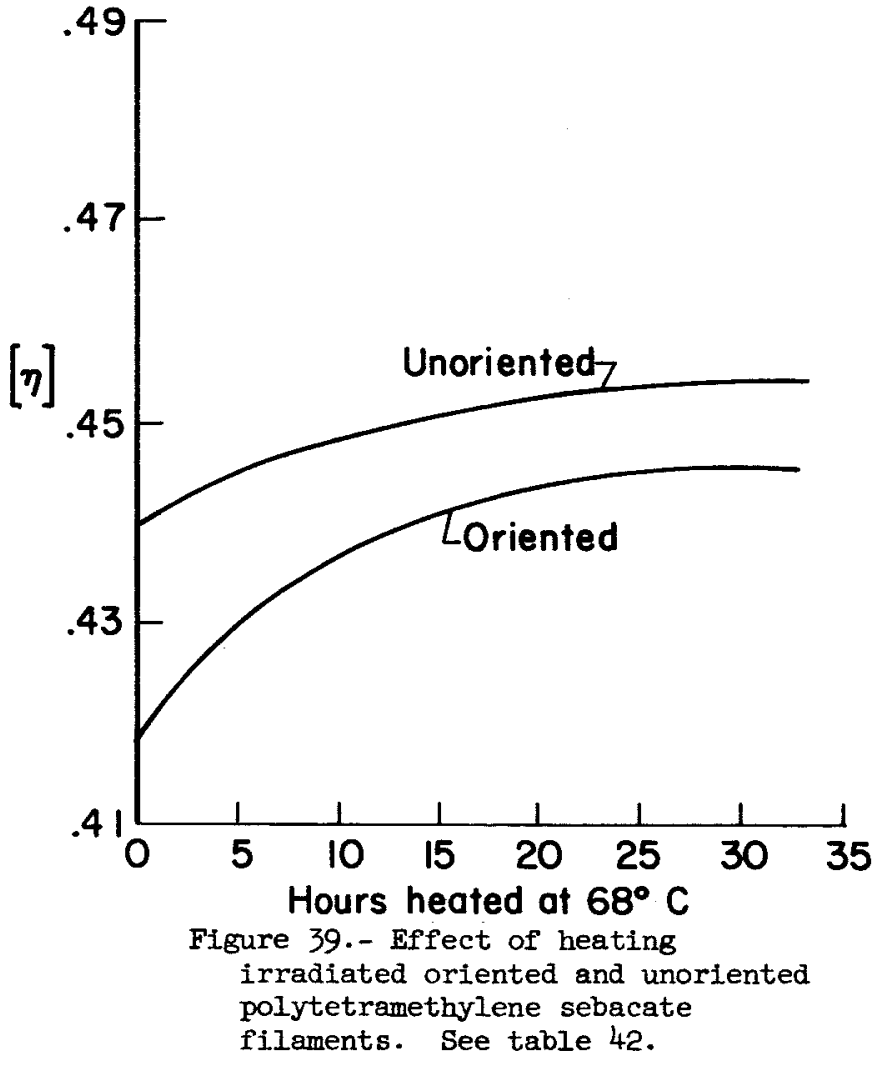




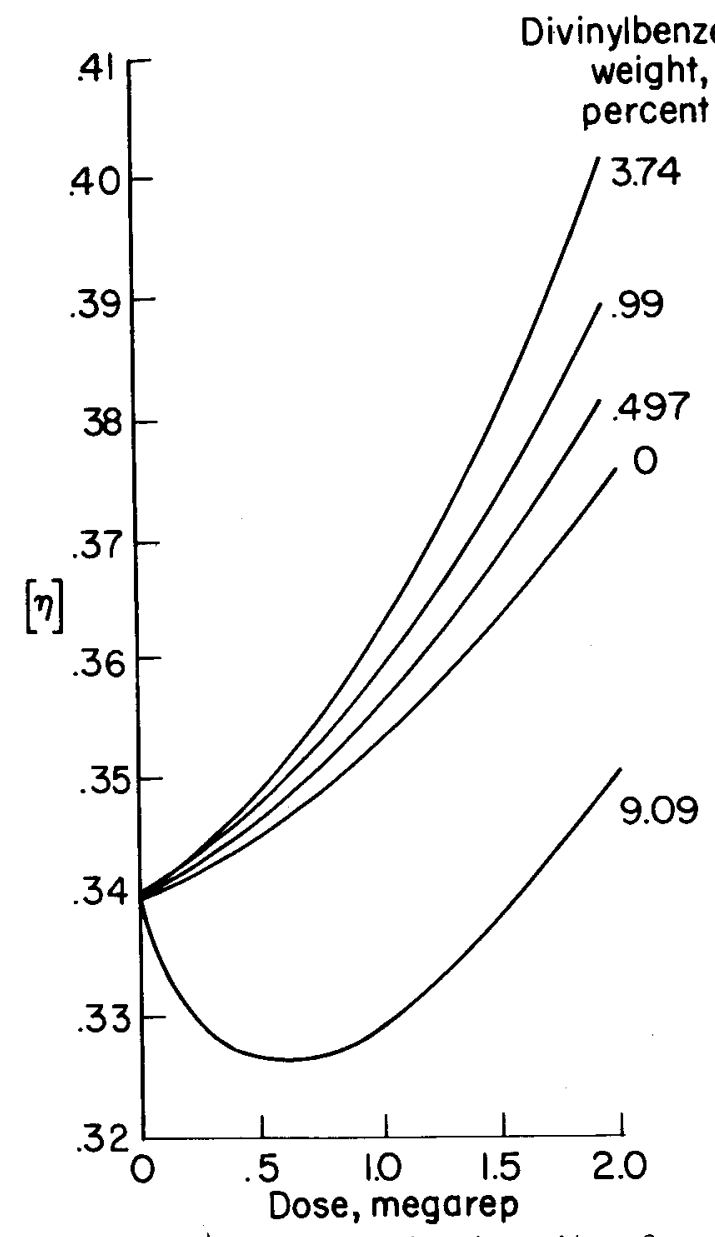

Figure 40.- Intrinsic viscosity of mixtures of polytetramethylene sebacate and divinylbenzene. see table 46.

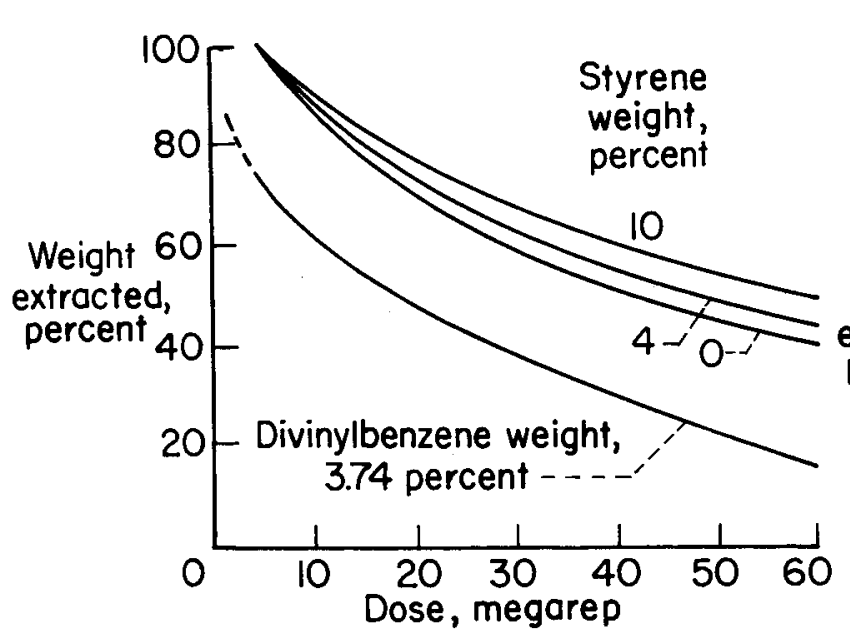

Figure 42.- Effect of irradiation on solubility of mixtures of polytetramethylene sebacate and styrene. See table 48 .

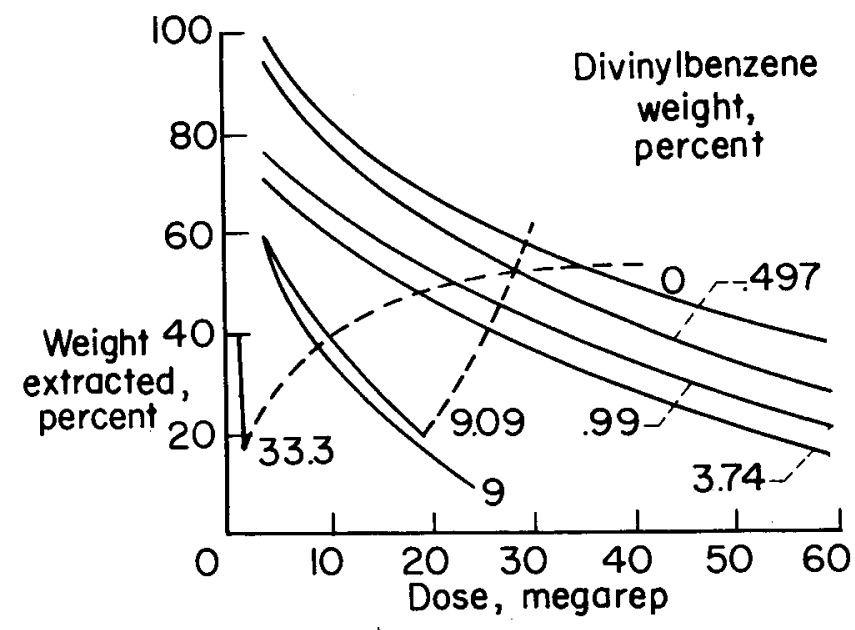

Figure 41.- Effect of irradiation on solubility of mixtures of polytetramethylene sebacate and divinylbenzene. See table 47.

Divinylbenzene weight, percent

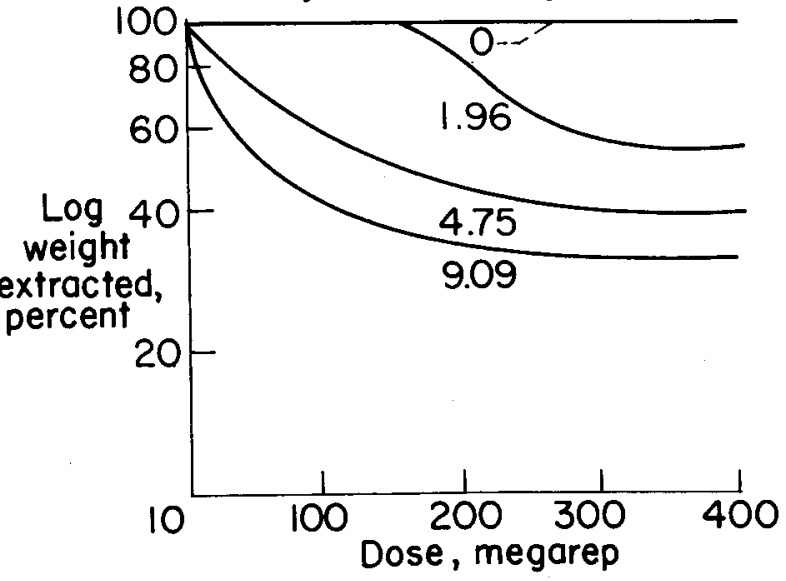

Figure 43.- Effect of irradiation on solubility of mixtures of polyethylene succinate and divinylbenzene. See table 49. 


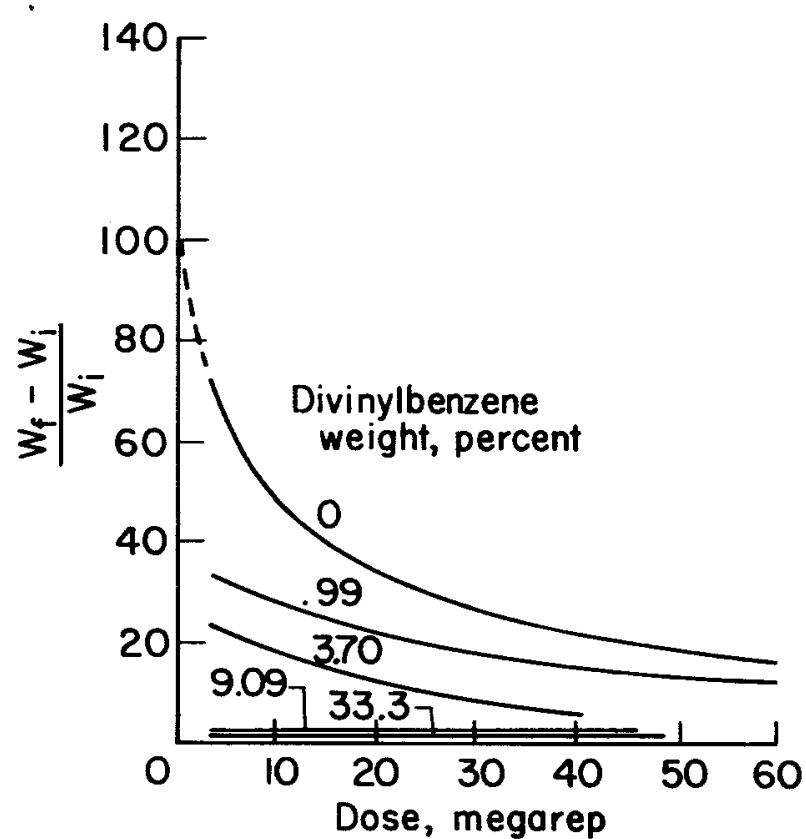

Figure 44.- Swelling index of irradiated mixtures of polytetramethylene sebacate and divinylbenzene.

See table 50 .

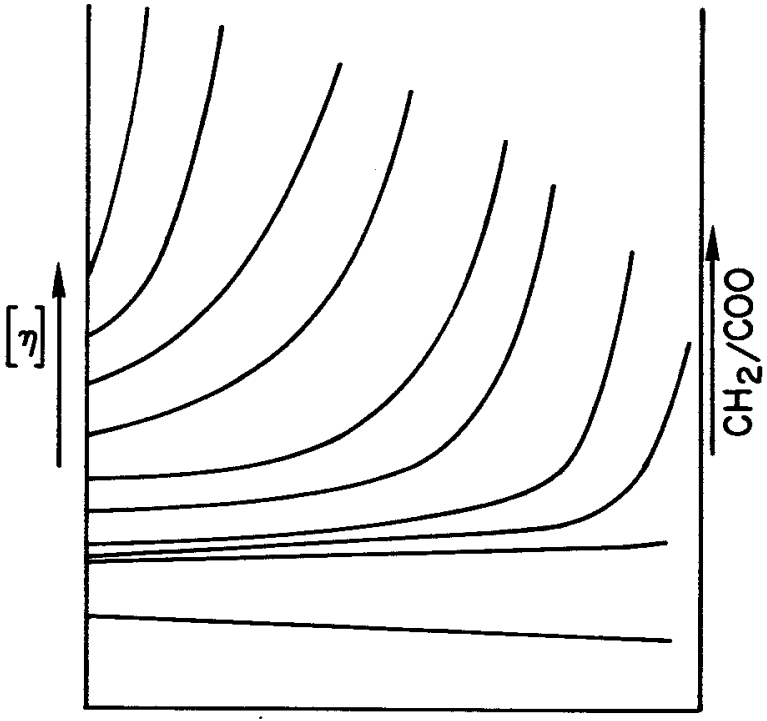

\section{Radiation dose}

Figure 45.- Generalized effect of irradiation dose on polyesters. 